UNIVERSIDADE DE BRASÍLIA

FACULDADE DE TECNOLOGIA

DEPARTAMENTO DE ENGENHARIA ELÉTRICA

\title{
REGULAÇÃO DO ESPECTRO DE RADIOFREQÜÊNCIAS - UMA ANÁLISE TÉCNICA DO MODELO BRASILEIRO
}

\section{THYAGO RODRIGUES COIMBRA}

ORIENTADOR: ANTONIO JOSÉ MARTINS SOARES

PROJETO FINAL DE GRADUAÇÃO EM ENGENHARIA ELÉTRICA

BRASÍLIA/DF: MARÇO - 2006 
UNIVERSIDADE DE BRASÍLIA

FACULDADE DE TECNOLOGIA

DEPARTAMENTO DE ENGENHARIA ELÉTRICA

REGULAÇÃO DO ESPECTRO DE RADIOFREQÜÊNCIAS UMA ANÁLISE TÉCNICA DO MODELO BRASILEIRO

THYAGO RODRIGUES COIMBRA

MONOGRAFIA SUBMETIDA AO DEPARTAMENTO DE ENGENHARIA ELÉTRICA DA FACULDADE DE TECNOLOGIA DA UNIVERSIDADE DE BRASÍLIA COMO PARTE DOS REQUISITOS NECESSÁRIOS À OBTENÇÃO DO GRAU DE ENGENHEIRO ELETRICISTA.

\section{APROVADA POR:}

Prof. Antonio José Martins Soares, Doutor, ENE-UnB (Orientador)

Prof. Lúcio Martins da Silva, Doutor, ENE-UnB (Examinador Interno)

Eng. Júlio César Fonseca, Gerência de Certificação-Anatel (Examinador Externo)

BRASÍLIA/DF, 23 DE MARÇO DE 2006 


\section{FICHA CATALOGRÁFICA}

COIMBRA, THYAGO RODRIGUES

Regulação do Espectro de Radiofreqüências - uma Análise Técnica do Modelo Brasileiro [Distrito Federal] 2006.

xi, 78 p., 210 x 297 mm (ENE/FT/UnB, Graduação, Engenharia Elétrica, 2006).

Projeto Final de Graduação - Universidade de Brasília. Faculdade de Tecnologia.

Departamento de Engenharia Elétrica.

1.Regulação

2.Radiofreqüência

3.Telecomunicação

4. Anatel

I. ENE/FT/UnB

II. Título (série)

\section{REFERÊNCIA BIBLIOGRÁFICA}

COIMBRA, T. R. Regulação do Espectro de Radiofreqüências - uma Análise Técnica do Modelo Brasileiro. Monografia (Graduação em Engenharia Elétrica) - Departamento de Engenharia Elétrica da Faculdade de Tecnologia. Brasília: Universidade de Brasília, 2006.

\section{CESSÃO DE DIREITOS}

AUTOR: Thyago Rodrigues Coimbra.

TÍTULO: Regulação do Espectro de Radiofreqüências - uma Análise Técnica do Modelo Brasileiro.

GRAU: Engenheiro Eletricista

ANO: 2006

É concedida à Universidade de Brasília permissão para reproduzir cópias desta monografia de graduação e para emprestar ou vender tais cópias somente para propósitos acadêmicos e científicos. $\mathrm{O}$ autor reserva outros direitos de publicação e nenhuma parte desta monografia de graduação pode ser reproduzida sem autorização por escrito do autor.

Thyago Rodrigues Coimbra

thyagocoimbra@gmail.com 


\section{AGRADECIMENTOS}

A Deus em primeiro lugar. Criador de todo o universo, autor da minha vida, que me deu a oportunidade de iniciar este curso e forças para concluí-lo. Estou certo de que sem Ele eu não estaria sequer escrevendo estas palavras de agradecimento. Porque Dele, por Ele e para Ele são todas as coisas, inclusive a minha vida.

Aos meus pais, pela dedicação, carinho e desprendimento, e por sempre me incentivarem nos estudos, mesmo ao custo de muita saudade. Aos meus irmãos e demais familiares, especialmente a tia Derceni. A minha Ludmila, pelo amor, compreensão e carinho. Eu te amo, hoje e sempre.

Agradeço a todos meus amigos e colegas, e a todos que de alguma forma ajudaram na realização deste trabalho. Aos colegas da Anatel, pelas orientações e por generosamente compartilharem suas experiências: Julio César Fonseca, José Gustavo, Alex Pires, Luciano Coelho, João Sardeiro, Antônio Carlos de Azambuja e Luís Fernando.

Também agradeço aos professores do departamento de Engenharia Elétrica, que nesses cinco anos participaram de minha formação. Em especial, ao professor Antonio José Martins Soares, um verdadeiro mestre, a quem sou grato pela seriedade, dedicação e empenho em sua orientação sempre paciente e atenciosa, imprescindível para a realização deste trabalho. 


\section{RESUMO}

\section{REGULAÇÃO DO ESPECTRO DE RADIOFREQÜÊNCIAS - UMA ANÁLISE TÉCNICA DO MODELO BRASILEIRO}

A possibilidade de utilização das ondas eletromagnéticas de radiofreqüência significou uma verdadeira revolução no campo das telecomunicações. Sendo o espectro radioelétrico um bem escasso, faz-se necessária a sua coordenação, de forma a garantir o uso adequado por todos os interessados. $\mathrm{O}$ assunto ganha maior importância nos dias atuais em função da crescente demanda por serviços móveis, entre os quais se destacam a telefonia celular e as redes de dados em banda larga sem fio.

A proposta deste trabalho é analisar o histórico e o atual momento da regulação de telecomunicações, com especial ênfase ao caso brasileiro, principalmente após a edição da Lei Geral das Telecomunicações, bem como a atuação do ente regulador, a Agência Nacional de Telecomunicações.

Os principais aspectos abordados estão relacionados a: gerenciamento e administração do espectro, ações de fiscalização e monitoramento, e interação entre campos eletromagnéticos de radiofreqüência e tecidos biológicos. Também pretende-se analisar o uso não-licenciado do espectro e os equipamentos de radiação restrita, além do processo de certificação e homologação de produtos para telecomunicações. A proposta é proceder a uma leitura dos assuntos relacionados à regulação do espectro, a partir de uma perspectiva técnica, isto é, do ponto de vista da engenharia. 


\section{ABSTRACT}

\section{RADIOFREQUENCY SPECTRUM REGULATION - A TECHNICAL ANALYZE OF THE BRAZILIAN MODEL}

The possibility of radiofrequency electromagnetic waves utilization meant a real revolution at the telecommunications field. Being the RF spectrum a scarce good, it is necessary its coordination, in such a way to ensure the appropriate use by everyone concerned. Nowadays, this subject takes grater weight, because of the mobile services rising demand, among which, the mobile telephony and the wireless broadband data networks are highlighted.

This work intends to analyze the historic and current telecommunications regulation moment, with special emphasis to the Brazilian case, chiefly after the edition of the General Telecommunications Law, as well as the actuation of the regulator entity, the National Telecommunications Agency.

The main approached aspects are related to: spectrum management and administration, surveying and monitoring actions, and interaction between radiofrequency electromagnetic fields and biological tissues. It is also intended to analyze the spectrum unlicensed usage and the low power devices, besides the telecommunications equipments certification and homologation process. The proposition is to proceed a reading of the subjects related to spectrum regulation, from a technical perspective, this is, an engineering point of view. 


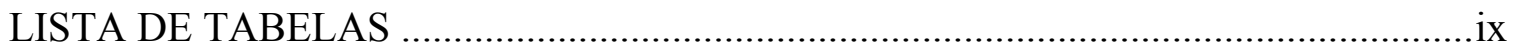

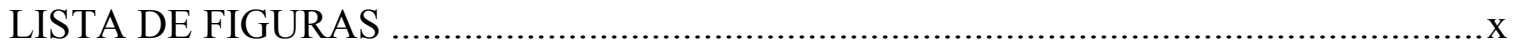

1. INTRODUÇÃO.....................................................................................1

2. HISTÓRICO DA REGULAÇÃO DO ESPECTRO DE

RADIOFREQÜÊECIAS ..................................................................................3

2.1 INTRODUÇÃO

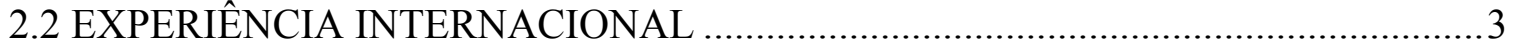

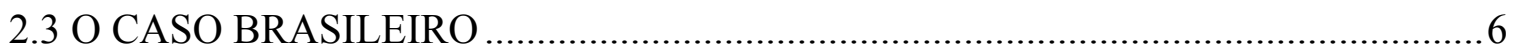

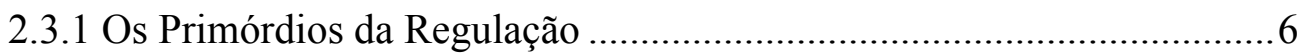

2.3.2 O Código Brasileiro de Telecomunicações ………………………….......

2.3.3 O Modelo Brasileiro após a Lei Geral das Telecomunicações..................8

3. FISCALIZAÇÃO E CONTROLE DO ESPECTRO .............................10

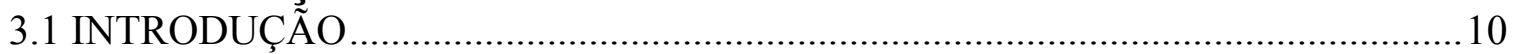

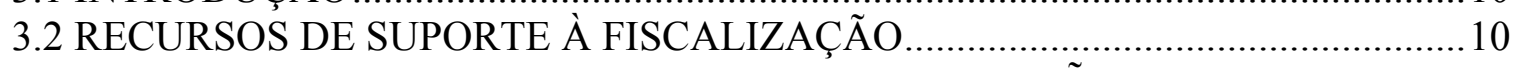

3.3 ESTUDOS DE CASO - ATIVIDADES DE FISCALIZAÇÃO .....................................11

3.3.1 - Emissoras de Radiodifusão Sonora em FM..........................................11

3.3.2 - Estações Rádio-Base do Serviço Móvel Pessoal..................................14

4. USO NÃO-LICENCIADO DE RADIOFREQÜÊNCIA........................17

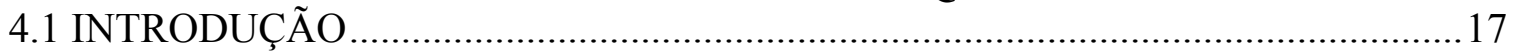

4.2 CASO GERAL: USO LICENCIADO DE RF ………….........................................18

4.3 PRINCÍPIOS DO REGULAMENTO PARA USO NÃO-LICENCIADO DE RF .....18

4.4 TECNOLOGIAS EMPREGADAS EM EQUIPAMENTOS PARA USO NÃO-

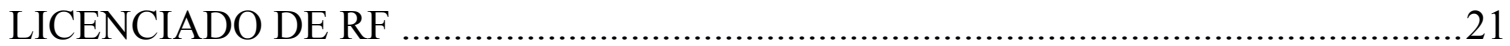

4.4.1 Técnicas de Espalhamento Espectral.................................................22

4.4.2 Multiplexação Ortogonal por Divisão de Freqüência..............................23

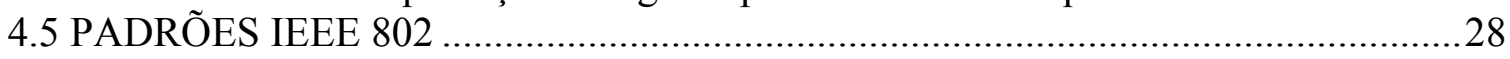

4.5.1 Bluetooth - Padrão 802.15.1 …………………..............................29

4.5.2 Wi-Fi - Padrão 802.11 ....................................................................

4.6 EXEMPLO DE UM EQUIPAMENTO DE RADIAÇÃO RESTRITA ........................32

5. EXPOSIÇÃO HUMANA A RADIAÇÃO ELETROMAGNÉTICA......37

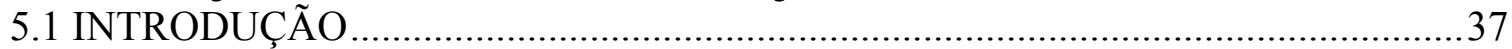

5.2 RADIAÇÃO IONIZANTE E RADIAÇÃO NÃO-IONIZANTE .................................38

5.2.1 Interação entre o Corpo Humano e a Radiação Não Ionizante...............39

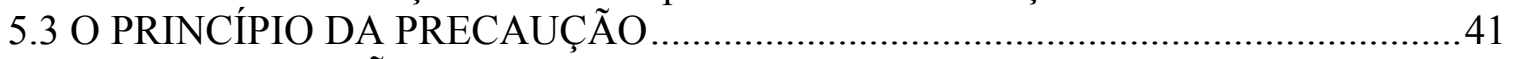

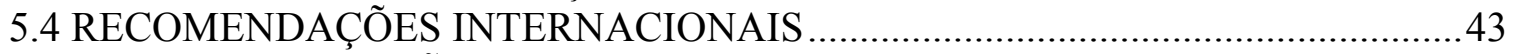

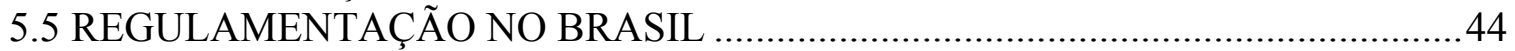

5.5.1 Verificação do Atendimento aos Limites .............................................4 4

5.5.2 Conflitos de Competência ....................................................................49

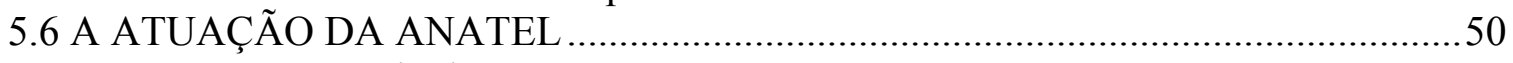

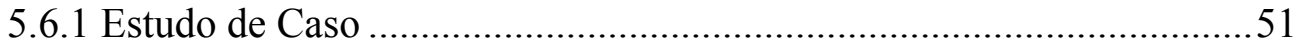

6. CERTIFICAÇÃO E HOMOLOGAÇÃO DE PRODUTOS PARA

TELECOMUNICAÇÃO ........................................................................54

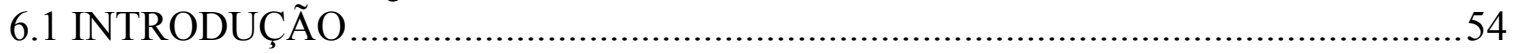




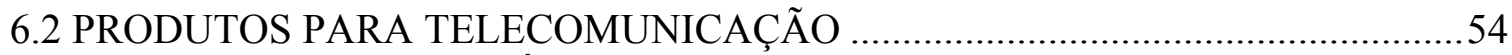

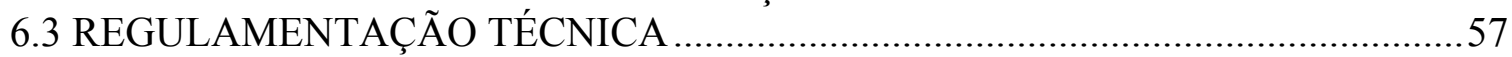

6.3.1 Situações de Inexistência de Regulamentos .......................................6 60

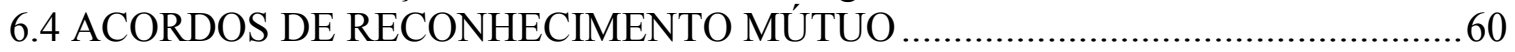

6.5 O PROCESSO DE CERTIFICAÇÃO E HOMOLOGAÇÃO ....................................61

6.5.1 Organismos de Certificação Designados ...........................................6 62

6.5.2 Avaliação da Conformidade ...........................................................62

6.5.3 Ensaios Realizados em Laboratório do Próprio Fabricante..................6 63

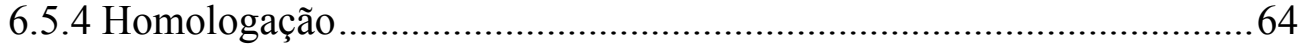

6.5.5 Homologação por Famílias de Produtos................................................6 65

6.6 COMPATIBILIDADE ELETROMAGNÉTICA, SEGURANÇA ELÉTRICA E

EXPOSIÇÃO A RADIAÇÃO NÃO-IONIZANTE ....................................................66

6.6.1 Compatibilidade Eletromagnética ..................................................67

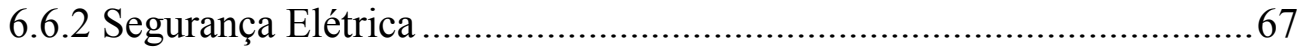

6.6.3 Exposição a Radiação não-Ionizante.................................................6 68

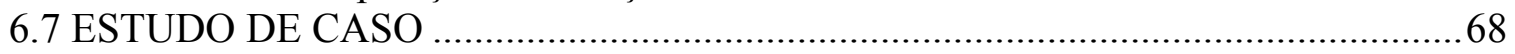

7. CONCLUSÃ̄ .................................................................................................... 73

REFERÊNCIAS BIBLIOGRÁFICAS ..................................................75 


\section{LISTA DE TABELAS}

Tabela 3.1 - Medições realizadas na atividade de fiscalização............................................. 16

Tabela 4.1 - Faixas com restrições de uso de equipamentos de radiação restrita....................19

Tabela 4.2 - Limites gerais de emissão para equipamentos de radiação restrita .....................19

Tabela 4.3 - Faixas de freqüências de operação dos equipamentos........................................20

de radiocomunicação de radiação restrita para aplicações específicas....................................20

Tabela 4.4 - Resultado dos ensaios para o requisito de separação de portadoras .....................34

Tabela 4.5 - Resultado dos ensaios para o requisito de tempo médio de ocupação ..................34

Tabela 4.6 - Resultado dos ensaios para o requisito de potência de pico de saída ...................35

Tabela 4.7 - Resultado dos ensaios para o requisito de potência de RF fora da faixa..............35

Tabela 5.1 - Restrições básicas para limitação a campos eletromagnéticos de RF .................45

Tabela 5.2 - Limites para exposição ocupacional a campos eletromagnéticos de RF .............46

Tabela 5.3 - Limites para exposição da população em geral a campos eletromagnéticos de RF

Tabela 5.4 - Expressões para cálculo de distâncias mínimas a antenas.................................48

transmissoras para atendimento aos limites de exposição..................................................48

Tabela 5.5 - Resultado da fiscalização sob estudo de caso e comparação com a regulamentação .................................................................................................5

Tabela 6.1 - Produtos que fazem uso de radiofreqüência passíveis de certificação .................55

Tabela 6.2 - Resoluções aprovadas pela Anatel no âmbito da certificação de produtos. .........58

Tabela 6.3 - Emolumentos para homologação definidos pela Resolução 242/2000 ................65

Tabela 6.4 - Limites para elevação de temperatura ............................................................ 68 


\section{LISTA DE FIGURAS}

Figura 2.1 - Regiões da UIT para planejamento de atribuição do espectro de radiofreqüências.

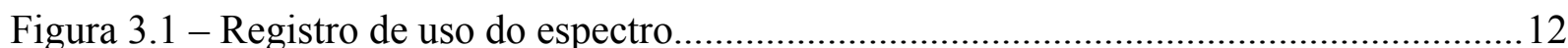

Figura 3.2 - Registro fotográfico do sistema radiante...................................................... 12

Figura 3.3 - Registro fotográfico do transmissor de radiofreqüência de fabricação caseira..... 13

Figura 3.4 - Registro fotográfico do estúdio................................................................ 13

Figura 3.5 - Registro fotográfico da região onde foram realizadas as medições..................... 15

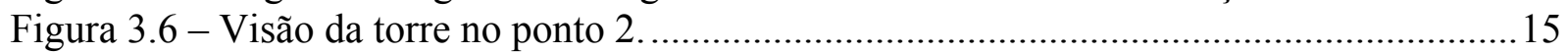

Figura 3.7 - Visão da torre no ponto 3 ........................................................................ 15

Figura 4.1 - Transmissão utilizando Espalhamento Espectral com Salto em Freqüência........23

Figura 4.2 - Transmissão e Recepção utilizando Espalhamento Espectral com Salto em

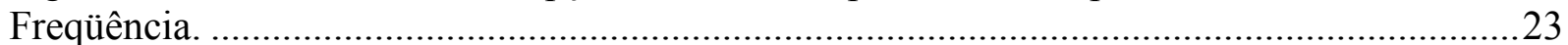

Figura 4.3 - Representação genérica de um símbolo digital no domínio do tempo.................24

Figura 4.4 - Processo de geração de um sinal OFDM no domínio do tempo em banda base através da operação IFFT sobre um trem de bits................................................................25

Figura 4.5 - Processo detalhado de geração de sinal OFDM no domínio do tempo em banda base através de um processamento da IFFT e da conversão paralelo-série.............................25

Figura 4.6 - Transmissão de um sinal OFDM através de uma portadora de RF. ....................26

Figura 4.7 - Representação no domínio do tempo de três sub-portadoras ortogonais..............26

Figura 4.8 - Representação no domínio da freqüência de três sub-portadoras ortogonais. ......27

Figura 4.9 - Espectro de oito sub-portadoras associadas em FDM......................................28

Figura 4.10 - Espectro de oito sub-portadoras associadas em OFDM, e indicação da banda de

freqüências economizada em comparação com a técnica FDM...........................................22

Figura 4.11 - Transmissão e recepção em um canal FH/TDD do Bluetooth............................30

Figura 4.12 - Computador de mão modelo Tungsten E2 com tecnologia Bluetooth. ...............32

Figura 4.13 - Configuração de ensaio para o Tungsten E2 ..................................................33

Figura 4.14 (a) - Separação de Canais de Salto medida entre canal inicial e central ................34

Figura 4.14 (b) - Separação de Canais de Salto medida entre canal central e final..................34

Figura 4.15 (a) - Tempo de ocupação de um canal de salto .................................................35

Figura 4.15 (b) - Número de repetições num intervalo de $0,4 \mathrm{~s}$...........................................35

Figura 4.16 (a) - Potência de RF na faixa de $30 \mathrm{MHz}$ a $1500 \mathrm{MHz}$......................................36

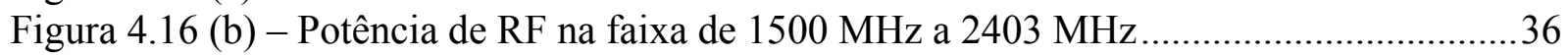

Figura 4.16 (c) - Potência de RF na faixa de $2479 \mathrm{MHz}$ a $2579 \mathrm{MHz}$...................................36

Figura 4.16 (d) - Potência de RF na faixa de 2,4 GHz a 18,0 GHz .....................................36

Figura 5.1 - Divisão do espectro eletromagnético entre radiação ionizante e RNI. ................38

Figura 5.2 - Simulação computacional de exposição a radiação não-ionizante em uma cabeça

humana, aplicando o método FDTD................................................................................. 40

Figura 5.3 - Vista do local onde se realizou a fiscalização .................................................52

Figura 5.4 - Vista do local onde se realizou a fiscalização.................................................52

Figura 5.5 - Vista do local onde se realizou a fiscalização ...................................................52

Figura 5.6 - Vista do local onde se realizou a fiscalização...................................................52

Figura 6.1 - Antena modelo GI 09 25. (a) perspectiva; (b) foto do selo Anatel de homologação. 
Figura 6.2 - Diagrama de radiação co-polar da antena modelo GI 09 25.............................. 70

(a) plano horizontal; (b) plano vertical ....................................................................... 70

Figura 6.3 - Certificado de Conformidade da antena modelo GI 09 25 ...............................71

Figura 6.4 - Certificado de Homologação da antena modelo GI 09 25.................................72 


\section{CAPÍTULO 1}

\section{INTRODUÇÃO}

Desde os primórdios da civilização, o ser humano tem verificado a necessidade de se comunicar. Inicialmente, os principais instrumentos para tal finalidade encontravam-se no próprio corpo, possibilitando a comunicação oral. Em seguida, passou-se a utilizar alguns artefatos simples, como tambores e sinais de fumaça, e em seguida um grande passo foi a invenção da escrita. Contudo, foi com o uso da eletricidade que as comunicações tiveram sua grande revolução, em meados de século XIX, a partir do invento do telégrafo e posteriormente do telefone, inaugurando a era das telecomunicações, isto é, comunicações a distância.

Os avanços tecnológicos seguintes permitiram a utilização das ondas eletromagnéticas de radiofreqüência em telecomunicações, o que foi mais um marco importante, representando o início das comunicações móveis e sem fio. Contudo, apesar das diversas vantagens das comunicações em RF, observou-se um grande problema: o fato de ser o espectro de radiofreqüências um bem escasso. Assim, quando duas fontes emissoras próximas transmitem utilizando a mesma faixa de freqüências, os sinais serão combinados, de forma que, na recepção, cada um causará interferência no outro, em alguns casos impossibilitando a comunicação.

Dessa forma, desde o início, verificou-se a necessidade de se coordenar o uso do espectro radioelétrico, tal que todos os interessados possam ter acesso de maneira satisfatória às comunicações sem fio. Em função da utilização do espectro ter forte caráter social, uma vez que de seu uso depende uma série de serviços importantes para a sociedade, o papel de regulador desse bem público tem sido, em geral, exercido pelo Estado.

No campo da regulação do espectro, alguns assuntos têm mostrado maior destaque, sendo a proposta do presente trabalho analisá-los à luz do conhecimento técnico, isto é, do ponto de vista da engenharia. O Capítulo 2 apresenta um breve histórico da regulação do espectro, a partir dos fundamentos da regulação de telecomunicações, tanto a experiência internacional quanto, com maiores detalhes, o caso brasileiro. Faz-se um levantamento dos principais dispositivos normativos aplicáveis ao setor desde o início do século XX, passando pelo marco que foi a edição do Código Brasileiro de Telecomunicações em 1962, até a edição da Lei Geral das Telecomunicações, que criou o órgão regulador - a Agência Nacional de 
Telecomunicações (Anatel) - e que atualmente é a base do arcabouço regulatório das telecomunicações.

O Capítulo 3 trata da fiscalização do uso do espectro radioelétrico, de competência da Anatel. São discutidos os instrumentos de que dispõe a Agência para execução dessa função e são apresentados estudos de casos baseados em ocorrências de fiscalização realizadas por fiscais da Anatel.

No Capítulo 4, é discutido o uso não-licenciado de radiofreqüência por de equipamentos de radiação restrita. Apresenta-se o Regulamento sobre Equipamentos de Radiocomunicação de Radiação Restrita, aprovado pela Resolução da Anatel n. ${ }^{\text {365, de }} 13$ de maio de 2004, que estabelece os requisitos técnicos aplicáveis aos equipamentos que não necessitam de autorização para uso do espectro nem de licença para funcionamento da estação, devido às baixas potências envolvidas. É ainda apresentada uma breve discussão a respeito das tecnologias empregadas por alguns equipamentos utilizados em redes locais sem fio, destacando-se os padrões Wi-Fi e Bluetooth.

Um dos assuntos de maior destaque entre a sociedade, devido aos receios e falta de conhecimento adequado, é a questão da exposição humana a radiação eletromagnética de radiofreqüências, que é apresentada no Capítulo 5. São apresentados os estudos internacionais que fundamentam as recomendações dos diversos organismos que se dedicam ao assunto. Também descreve-se o tratamento que essa questão recebe no Brasil, com destaque para a atuação da Anatel, tanto para regulamentar quanto para fiscalizar o atendimento aos limites de intensidade de campos eletromagnéticos e de potência de radiofreqüência a que os seres humanos podem se expostos sem implicar em risco à saúde.

Finalmente, no Capítulo 6, discute-se o tema da certificação e homologação de produtos para telecomunicações. Apresenta-se em detalhes o processo de certificação, com destaque para o papel dos Organismos de Certificação Designados (OCD) que acompanham os ensaios realizados nos produtos e, constatado o atendimento aos requisitos técnicos e processuais, emite um Certificado de Conformidade a ser homologado pela Anatel. O capítulo é encerrado com um estudo de caso em que se analisa o processo de certificação de uma antena. 


\section{CAPÍTULO 2}

\section{HISTÓRICO DA REGULAÇÃO DO ESPECTRO DE RADIOFREQÜÊNCIAS}

\subsection{INTRODUÇÃO}

Embora a possibilidade de aplicação da radiocomunicação tenha sido verificada também por outras pessoas, a fama mundial de demonstrar a utilidade do rádio como meio de telecomunicação pertence a Guglielmo Marconi (1874-1937). No início, o rádio foi utilizado principalmente como meio de comunicação a longa distância, especialmente com navios. A radiotelegrafia - a comunicação de telegramas através de técnicas de radiofreqüência (RF) - foi o primeiro serviço a utilizar comunicação sem fio, a partir da última década do século XIX. Em 1901, nos Estados Unidos, foi reconhecida a primeira patente para radiotelefonia, ou seja, a transmissão de voz por meio de ondas eletromagnéticas de RF. Essa tecnologia permitiu o surgimento da radiodifusão, que se iniciou em 1921 com a instalação de estações transmissoras em Pittsburgh e Nova Iorque, seguida, dois anos depois, pela entrada em operação de estações brasileiras, em Recife e no Rio de Janeiro. Cabe destacar que, embora largamente utilizado pela população leiga com esse sentido, o termo rádio (ou radiocomunicação) não se refere apenas à radiodifusão sonora, mas a todos os sistemas de comunicação sem fio que fazem uso do espectro eletromagnético de RF.

Assim como foram reconhecidas de imediato as possibilidades comerciais do novo meio de comunicação, também foram verificados os problemas de interferência quando duas estações na mesma localidade transmitem na mesma freqüência ou em freqüências próximas uma da outra, prejudicando a recepção de ambos os sinais. Neste capítulo, pretende-se analisar o histórico da regulação do espectro de radiofreqüências (RF) desde o início de seu uso para aplicações de telecomunicação até o atual cenário, destacando o caso brasileiro.

\subsection{EXPERIÊNCIA INTERNACIONAL}

Um dos primeiros esforços para resolver o problema da interferência em radiocomunicação foi a adoção pela justiça americana do princípio da prioridade de uso, segundo o qual o primeiro usuário (transmissor) seria o dono da freqüência, e outros usuários 
teriam que utilizar outras freqüências [1]. Posteriormente verificou-se que esse princípio não atendia o interesse público e, de maneira geral, o espectro é considerado em todo mundo como um bem público e, portanto, é administrado por órgãos governamentais.

Como as ondas eletromagnéticas de radiofreqüência não são contidas por limites de fronteiras geográficas, é necessário que seu gerenciamento seja realizado internacionalmente, especialmente no que concerne a proteção das garantias contra interferências e ao acesso às faixas de freqüência adequadas para cada aplicação. Dessa forma, o espectro de radiofreqüências tem sido primariamente, essencialmente e extensivamente regulado em nível internacional [2]. As primeiras regulamentações de RF em âmbito internacional tinham como objetivo evitar o monopólio de faixas de freqüência e assegurar a liberdade de correspondências para segurança na navegação e em outras comunicações, independentemente dos direitos de propriedade dos fabricantes de equipamentos.

Devido aos conflitos comerciais surgidos em virtude da comunicação entre embarcações e a costa, foi proposta a Conferência Preliminar de Telegrafia sem Fio, que ocorreu na Alemanha em 1903. Os nove países que se reuniram nessa conferência internacional concordaram que "estações costeiras devem ser obrigadas a receber e transmitir telegramas originados ou destinados a embarcações no mar sem distinção do sistema de rádio utilizado" [3]. Seguiu-se a Conferência de Radiotelegrafia de Berlim, em 1906, quando 29 países adotaram a Convenção Radiotelegráfica, originada da concordância do uso de sistemas abertos, da discussão de taxas e tarifas e do estabelecimento de procedimentos para comunicações entre navios e a costa. Em Londres, em 1912, ocorreu a Radio Conference, a partir da qual substituiu-se o termo wireless (do inglês, sem fio) por radio para denominar as comunicações que utilizam o espectro de RF.

Com exceção do período durante a I Guerra Mundial, entre 1914 e 1918, a regulação internacional de radiofreqüência continuou tendo progresso e outras conferências foram realizadas. O serviço radiotelefônico transatlântico se iniciou, utilizando controle de freqüência por cristal de quartzo e transmissão SSB (banda lateral simples). Com o advento de novas tecnologias de seleção de freqüência para transmissão e recepção, foram alocadas, na Conferência de Washington, em 1927, faixas de freqüências, entre $10 \mathrm{kHz}$ e $30 \mathrm{MHz}$, para 
aplicações de radiodifusão, radioamadorismo, serviços ponto-a-ponto e serviços móveis: marítimo, aeronáutico e terrestre [4].

Em 1932, na cidade de Madri, ocorreram a Conferência Geral de Regulação de Rádio, e a Conferência Internacional de Telegrafia, quando a União Internacional de Telegrafia (criada em 1895) mudou seu nome para União Internacional de Telecomunicações (UIT). Esse novo nome foi escolhido para refletir de forma mais apropriada o escopo completo de responsabilidades da União, que, a partir de então, passou a cobrir todas as formas de comunicação com fio e sem fio [4]. A UIT, que desde 1947 integra a Organização das Nações Unidas (ONU), é a principal entidade internacional relacionada a coordenação e padronização de telecomunicações e congrega atualmente 189 países membros, que são representados nos congressos, conferências, assembléias e demais eventos por integrantes das administrações nacionais; no caso do Brasil, pelo órgão regulador, a Anatel. As decisões acordadas no âmbito da UIT não têm força de lei, e nenhum país sofre sanção por não cumpri-las. Mas, normalmente, é de interesse dos países membros alinhar-se com os padrões adotados internacionalmente, por questões comerciais e de compatibilização dos sistemas.

A partir de 1948, a UIT dividiu o planeta em três regiões para planejamento da atribuição das faixas no espectro de radiofreqüência, pois a elaboração de planos de atribuição em escala global mostrou-se extremamente complexo. Assim, as atribuições de faixas de freqüências diferem entre as regiões, exceto nas aplicações que exigem compatibilidade dos sistemas nos diversos pontos do planeta, como no caso dos serviços móveis marítimo e aeronáutico. A Região 1 é composta pela Europa, África e parte da Ásia, a Região 2 pelas Américas e Groenlândia e a Região 3 pela Ásia e pela Oceania, como mostrado na Figura 2.1.

As décadas de 1950 a 1990 foram marcadas por diversas conferências organizadas pela UIT para elaboração de novas atribuições para o espectro, elevando continuamente seu limite superior até o valor atualmente normatizado: $3.000 \mathrm{GHz}$. Os avanços tecnológicos, especialmente o início do uso dos satélites para telecomunicações, obrigaram algumas revisões na regulação de RF adotada internacionalmente. Atualmente, o progresso tecnológico e a crescente demanda por novos serviços sem fio são as questões-chave para os envolvidos na regulação internacional do espectro radioelétrico e têm estimulado contínuos estudos de forma a melhor atender o interesse e a necessidade das populações. 


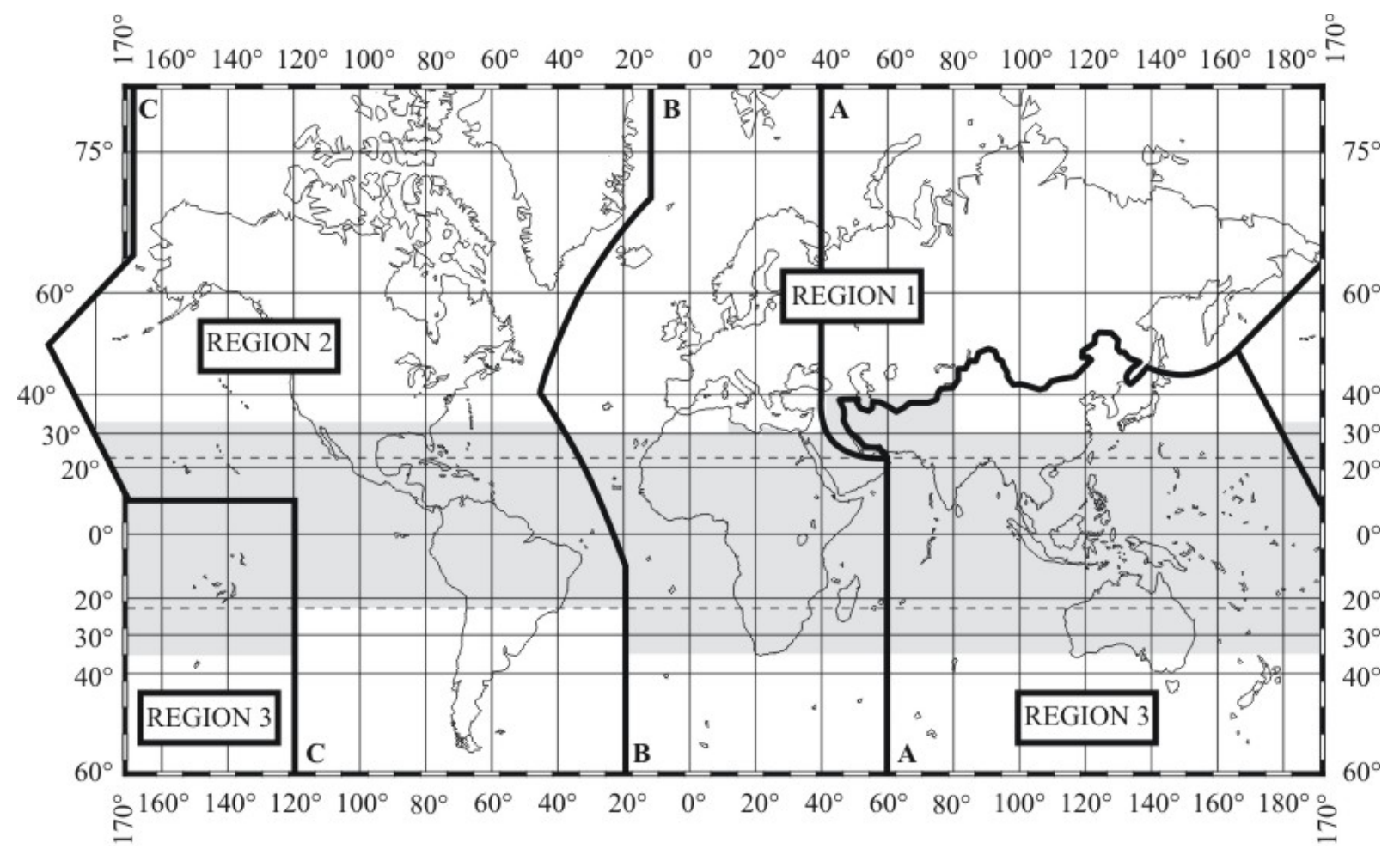

Figura 2.1 - Regiões da UIT para planejamento de atribuição do espectro de radiofreqüências.

\subsection{O CASO BRASILEIRO}

\subsubsection{Os Primórdios da Regulação}

O primeiro instrumento normativo que regulou o uso das comunicações via rádio no

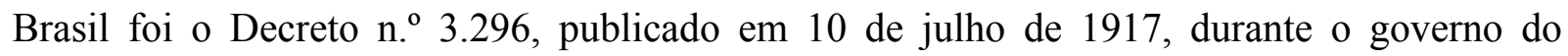
presidente Venceslau Brás (1914 - 1918). Este decreto estabeleceu que fossem "da exclusiva competência do Governo Federal os serviços radiotelegráfico e radiotelefônico no território brasileiro”. Definia também ser da competência do Ministério da Viação e Obras Públicas, em caso civil, e do Ministério da Guerra e Marinha, em caso de defesa nacional, o estabelecimento e exploração das estações radiotelegráficas.

Em 27 de maio de 1931 foi publicado o Decreto n. ${ }^{\circ}$ 20.047, estabelecendo normas para exploração dos serviços de radiocomunicação, fixando a radiodifusão como de exclusiva competência e responsabilidade do Estado, e definindo sua natureza e objetivos. Definia também o caráter do serviço de radiodifusão, que passava a ser considerado de interesse nacional e finalidade educacional. A preocupação com o controle dos serviços de 
radiocomunicação por parte da União era tamanha que o decreto criou uma ordem de precedência para a distribuição das freqüências, na qual vinham em primeiro e segundo lugares a defesa nacional e os serviços executados pelo Governo Federal, respectivamente, e, em último, os serviços executados pela iniciativa privada.

Em $1^{\circ}$ de março de 1932 foi expedido o Decreto n. ${ }^{\circ} 21.111$, que regulamentou o Decreto n. 20.047 e passou a ser a base principal para todos os decretos seguintes. Bastante completo, definia detalhadamente a natureza dos serviços de radiocomunicação, classificandoos quanto ao tipo de serviço (interior, internacional, público, restrito etc); definia ainda os termos técnicos utilizados e fixava as competências para cada tipo de serviço. Esse decreto também estabeleceu o processo a ser seguido na outorga de concessões e permissões de uso do espectro. Adicionalmente, foram estabelecidas as competências da Comissão Técnica do Rádio (subordinada ao ministério da Viação e Serviços Públicos), entre elas, distribuir, coordenar e consignar as freqüências a serem utilizadas nos serviços de radiocomunicações no território nacional [5].

Esses decretos foram mantidos inalterados pela Constituição de 1934 e pela Constituição outorgada por Getúlio Vargas em 1937. Eles só foram tornados sem efeito pelo Código Brasileiro de Telecomunicações, aprovado pelo Congresso Nacional em 1962.

\subsubsection{O Código Brasileiro de Telecomunicações}

Em 27 de agosto de 1962 foi aprovada a Lei n. ${ }^{\circ}$ 4.117, conhecida como Código Brasileiro de Telecomunicações (CBT), que marcou o início da fase instuticionalizada das telecomunicações no Brasil. Entre outros avanços, essa lei criou o Sistema Nacional de Telecomunicações, colocando sob jurisdição da União os serviços de telégrafo, radiocomunicação e telefonia interestadual; instituiu o Conselho Nacional de

Telecomunicações (Contel), e atribuiu-lhe a responsabilidade pela administração e regulamentação do espectro, tendo o Departamento Nacional de Telecomunicações (Dentel) como sua secretaria executiva; atribuiu à União competência para explorar diretamente os troncos de microondas que integravam o Sistema Nacional de Telecomunicações; e instituiu as bases para a criação da Telebrás e da Embratel [1,6]. O CBT trazia, no Artigo 33 reproduzido 
a seguir, os princípios do emprego ordenado e econômico do espectro e da prevenção contra interferências [7].

Art. 33. Os serviços de telecomunicações, não executados diretamente pela União, poderão ser explorados por concessão, autorização ou permissão, observadas as disposições da presente lei.

$\S 1^{\circ} \mathrm{Na}$ atribuição de freqüencia para a execução dos serviços de telecomunicações serão levadas em consideração:

a) o emprego ordenado e econômico do espectro eletromagnético;

b) as consignações de freqüências anteriormente feitas, objetivando evitar interferência prejudicial.

$\S 2^{\circ}$ Considera-se interferência qualquer emissão, irradiação ou indução que obstrua, total ou parcialmente, ou interrompa repetidamente serviços radioelétricos.

A atribuição de faixas de freqüências, a fiscalização do uso do espectro e as demais atividades regulamentares de RF cabiam ao Contel por determinação do CBT. Por força do Decreto-lei n. ${ }^{\circ}$ 200, de 25 de fevereiro de 1967, foi criado o Ministério das Comunicações, que absorveu o Contel e todas as suas atribuições. Assim, a regulação do espectro passou para a tutela do Ministério das Comunicações até a edição da Lei Geral das Telecomunicações, que, em 1997, criou a Agência Nacional de Telecomunicações (Anatel), órgão que atualmente tem essa competência.

\subsubsection{O Modelo Brasileiro após a Lei Geral das Telecomunicações}

A Lei Geral das Telecomunicações (LGT), Lei n. ${ }^{\circ}$ 9.472, de 16 de julho de 1997, foi o marco inicial do atual estado da regulamentação das telecomunicações no Brasil. Foi aprovada como conseqüência da Emenda Constitucional n. ${ }^{\circ}$ 8, de 15 de agosto de 1995, que alterou a Constituição Federal quebrando o monopólio estatal sobre a exploração dos serviços de telecomunicações. A LGT, além de prever a privatização das empresas prestadoras de telefonia, determinou a criação da Anatel, inaugurando o modelo regulatório atualmente vigente no País. Significou profundas alterações nas relações entre os agentes do mercado, determinando que a exploração dos serviços passasse da condição de monopólio à de competição e que o Estado passasse da função de provedor para a de regulador dos serviços [8]. 
A LGT aprimorou significativamente a regulação do espectro de RF. A preocupação com esse recurso escasso pode ser verificada desde o artigo $1^{\circ}$ da LGT, reproduzido a seguir, o qual deixa claro que o disciplinamento e a fiscalização da utilização do espectro cabem à Anatel [9].

Art. $1^{\circ}$ Compete à União, por intermédio do órgão regulador e nos termos das políticas estabelecidas pelos Poderes Executivo e Legislativo, organizar a exploração dos serviços de telecomunicações.

Parágrafo único. A organização inclui, entre outros aspectos, o disciplinamento e a fiscalização da execução, comercialização e uso dos serviços e da implantação e funcionamento de redes de telecomunicações, bem como da utilização dos recursos de órbita e espectro de radiofreqüências.

A LGT também prevê o uso eficiente do espectro como um dos objetivos do disciplinamento da exploração dos serviços, como forma de viabilizar o cumprimento das leis, em especial das relativas às telecomunicações, à ordem econômica e aos direitos dos consumidores. Adicionalmente, verifica-se a importância dada pela LGT à regulamentação do espectro de radiofreqüências, ao destinar dois de seus capítulos exclusivamente para tratar desse assunto (capítulo I - Do Espectro de Radiofreqüências, e II - Da Autorização de Uso de Radiofreqüência, no Título V - Do Espectro e da Órbita, no Livro III - Da Organização dos Serviços de Telecomunicações). O atual modelo brasileiro de regulação do espectro de radiofreqüências, inaugurado a partir da edição da LGT, é o objeto de estudo do presente trabalho. 


\section{CAPÍTULO 3}

\section{FISCALIZAÇÃO E CONTROLE DO ESPECTRO}

\subsection{INTRODUÇÃO}

Em virtude da grande demanda pelo uso do espectro, que também torna necessária sua coordenação, é indispensável que o ente regulador realize a fiscalização desse bem público, de forma a se garantir que os interessados que possuem autorização tenham condições de utilizar o espectro satisfatoriamente, bem como para coibir o uso de maneira imprópria por pessoas não autorizadas. Nesse sentido, as administrações dos diversos países têm aplicado esforços no sentido de garantir a correta utilização do espectro de RF, de acordo com as normas por elas adotadas, bem como punindo aqueles que infringem a legislação aplicável.

No Brasil, o responsável pela fiscalização do espectro de radiofreqüências é a Anatel, como órgão regulador do setor de telecomunicações. Os recursos e ferramentas utilizados pela Anatel para esse fim, e alguns exemplos de atividades fiscalizatórias por ela realizadas, são o objeto de análise deste capítulo.

\subsection{RECURSOS DE SUPORTE À FISCALIZAÇÃO}

Para a atividade de fiscalização, a Anatel dispõe de basicamente dois tipos de ação: as atividades presenciais, nas quais os fiscais vão a campo, até as instalações da entidade fiscalizada, verificar o atendimento ou não aos dispositivos legais e regulamentares aplicáveis ao uso do espectro; e as ações remotas, em que se utilizam equipamentos de radiomonitoragem, seja em estações fixas ou móveis.

No caso das ações presenciais, os fiscais se utilizam de equipamentos como medidores isotrópicos de intensidade de campos eletromagnéticos, analisadores de espectro, radiogoniômetros, wattímetros, e diversos outros equipamentos auxiliares para realização de medidas em radiofreqüência, além de equipamentos como bússolas e telêmetros para outras medições necessárias. As principais medidas realizadas são de potência, intensidade de campo, densidade de fluxo de potência, largura de faixa, freqüência e desvio, ocupação e análise espectral, índice de modulação, interferências, altura e azimute dos sistema irradiante, além da 
verificação do atendimento a regulamentos específicos, como por exemplo, a comprovação de certificação e homologação dos produtos para os quais esse procedimento é compulsório.

Para as atividades remotas, a principal ferramenta de que dispõe o quadro de fiscais da Agência é o Sistema de Gestão e Monitoragem do Espectro (SGME). Em 2005, mais de 90\% das ações de fiscalização realizadas pela Anatel se deram na forma de ações por monitoragem. O SGME é composto basicamente de 56 estações remotas (fixas), dispostas nas capitais e em algumas das cidades mais importantes do país, e 28 estações móveis (em veículos) disponíveis nas capitais dos estados. Os principais equipamentos utilizados nas ações presenciais também estão disponíveis nas estações remotas e móveis do SGME. Assim, as mais importantes medições citadas podem ser realizadas por meio desse sistema.

\subsection{ESTUDOS DE CASO - ATIVIDADES DE FISCALIZAÇÃO}

Passa-se agora a analisar, através de dois estudos de caso, os procedimentos das atividades de fiscalização realizadas pela Anatel no que se refere ao uso do espectro de radiofreqüências. Embora não seja mostrado a seguir nenhum exemplo de atividade que envolva ocorrência de interferência aos serviços de comunicação aeronáutica, cabe destacar a importância da fiscalização das faixas de freqüência utilizadas por esse serviço, uma vez que problemas na comunicação com aeronaves podem ocasionar acidentes com proporções catastróficas. Nesse sentido, a Anatel tem dado especial atenção ao assunto, e periodicamente realizam-se visitas a aeroportos e são efetuados contatos com as autoridades competentes.

\subsection{1 - Emissoras de Radiodifusão Sonora em FM}

O tipo mais comum de ocorrência que origina ações de fiscalização pela Anatel é a denúncia, por parte da sociedade, do funcionamento de estações de radiodifusão sem outorga para prestação do serviço (e, consequentemente, sem autorização para uso de radiofreqüência), as chamadas "rádios piratas". Apenas nos três primeiros trimestres de 2005, foram mais de seis mil denúncias. Em geral, a maioria das estações, além de não ser outorgada, infringe os requisitos para operação de estações de Radiodifusão Comunitária, ao transmitir potências superiores a $25 \mathrm{~W}$ e realizar proselitismo político, além de explorar comercialmente o serviço. 
A Figura 3.1 mostra o registro de uso do espectro, verificado em uma ação de fiscalização realizada pela Unidade Operacional da Anatel no Distrito Federal, em uma estação de radiodifusão sonora em FM, que operava ilegalmente, na freqüência central de 105,9 MHz, em São Sebastião. As demais figuras a seguir foram obtidas por meio de registro fotográfico nessa entidade. Verifica-se que o serviço não é executado pelos infratores com o profissionalismo necessário, conforme pode ser constatado pelo uso de um transmissor de fabricação caseira, além da desorganização do ambiente do estúdio.

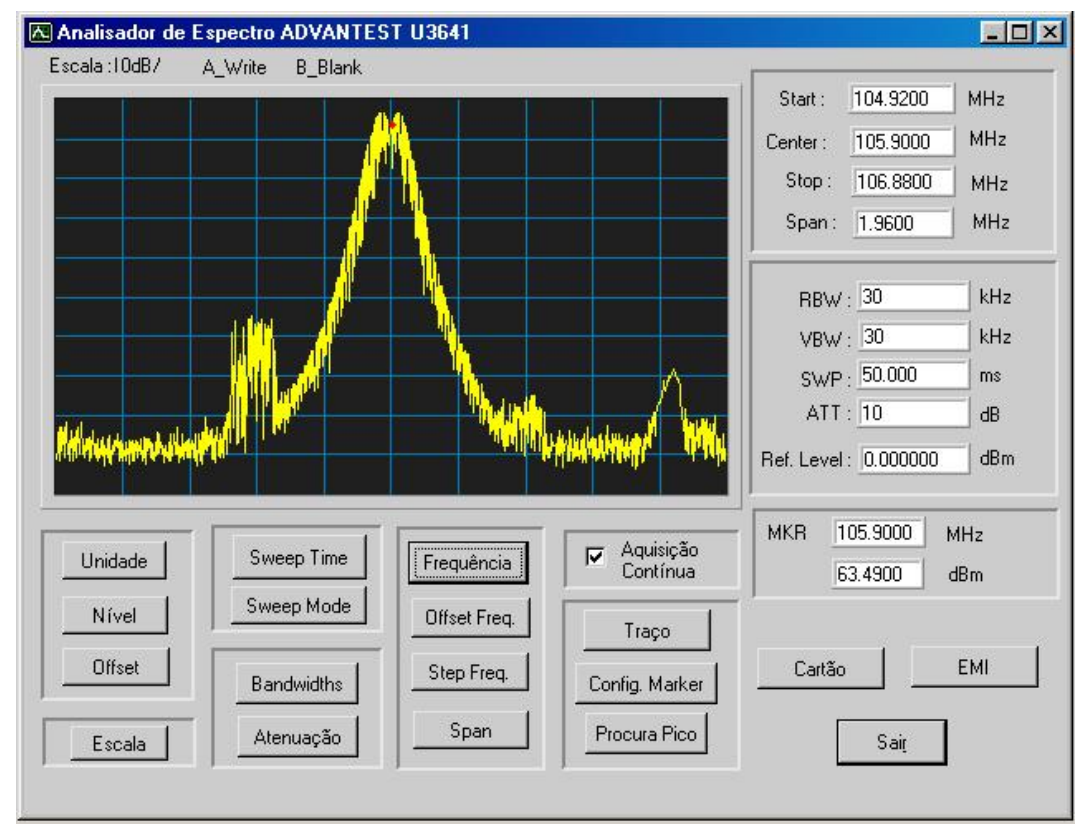

Figura 3.1 - Registro de uso do espectro.

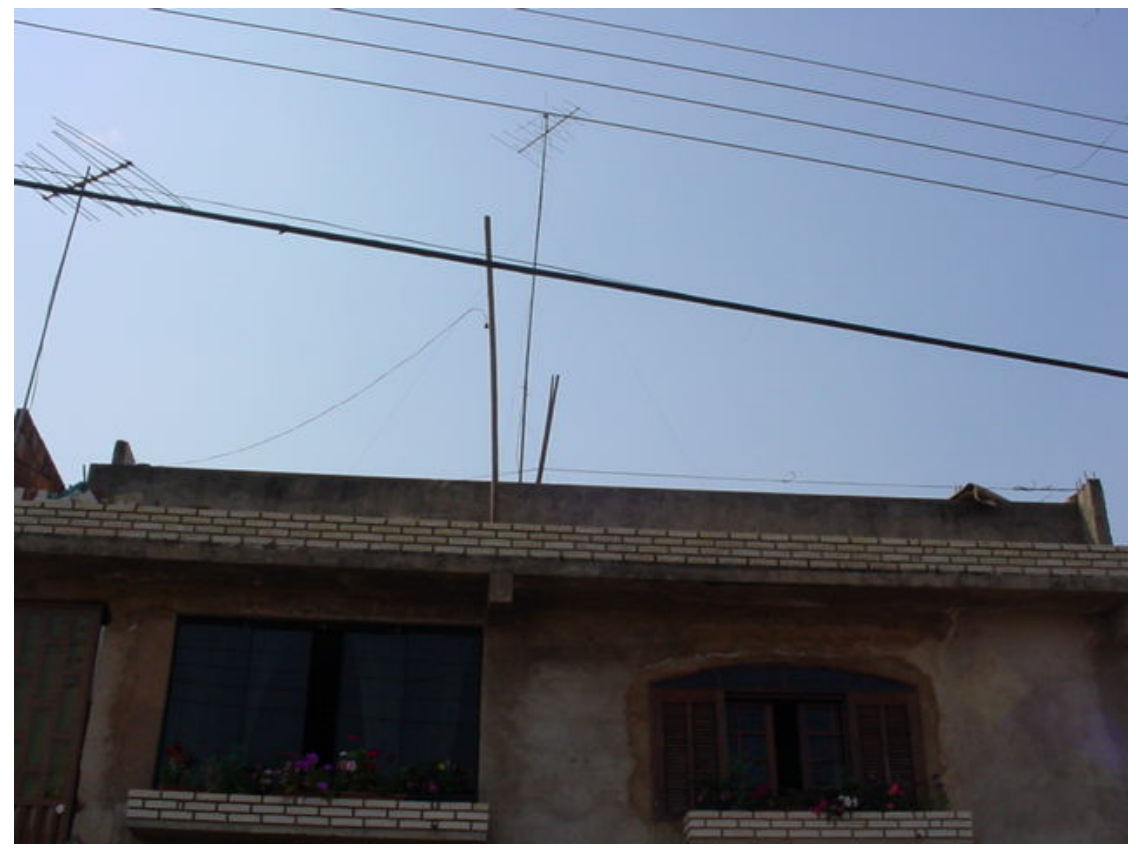

Figura 3.2 - Registro fotográfico do sistema radiante. 


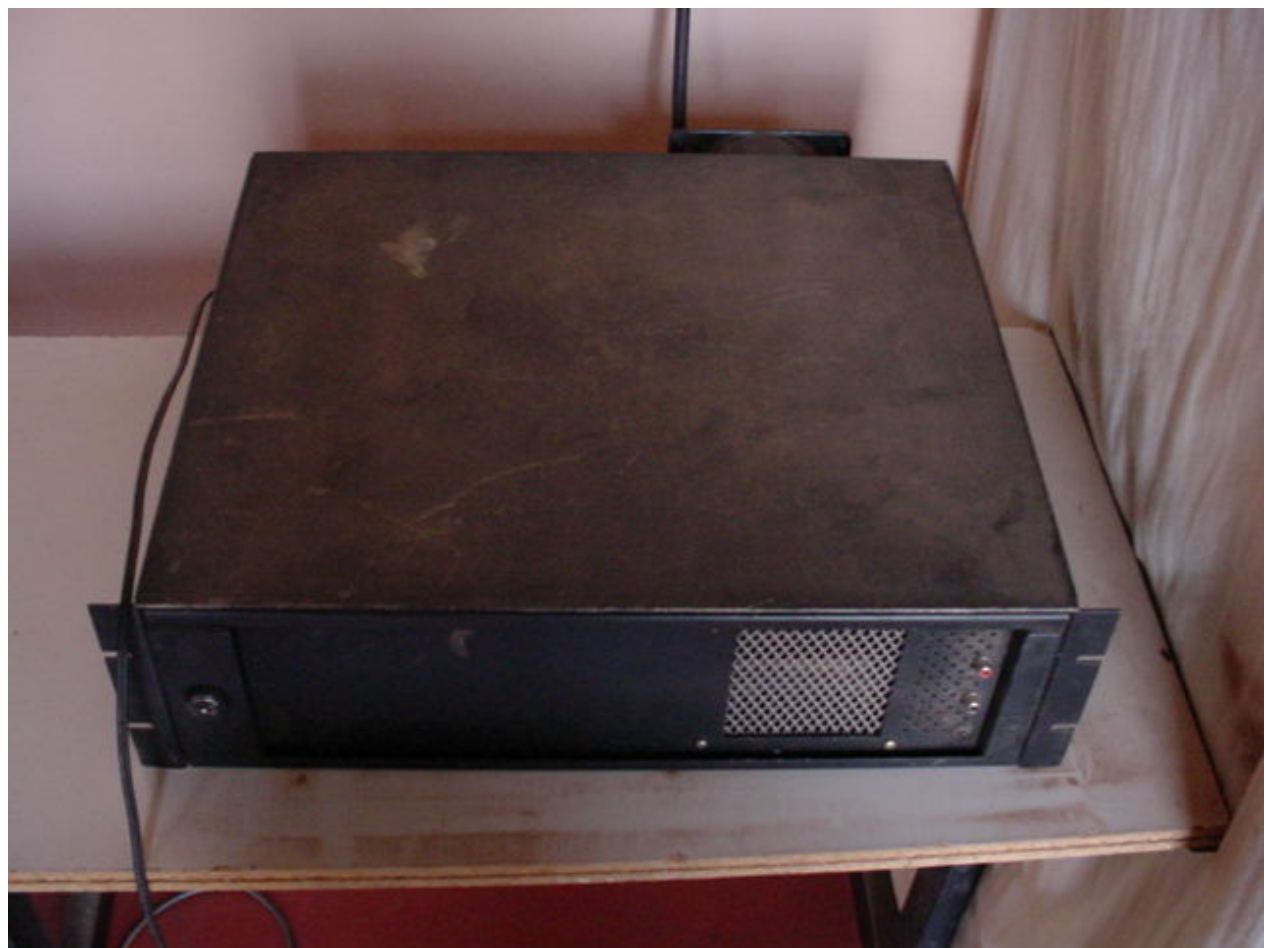

Figura 3.3 - Registro fotográfico do transmissor de radiofreqüência de fabricação caseira.

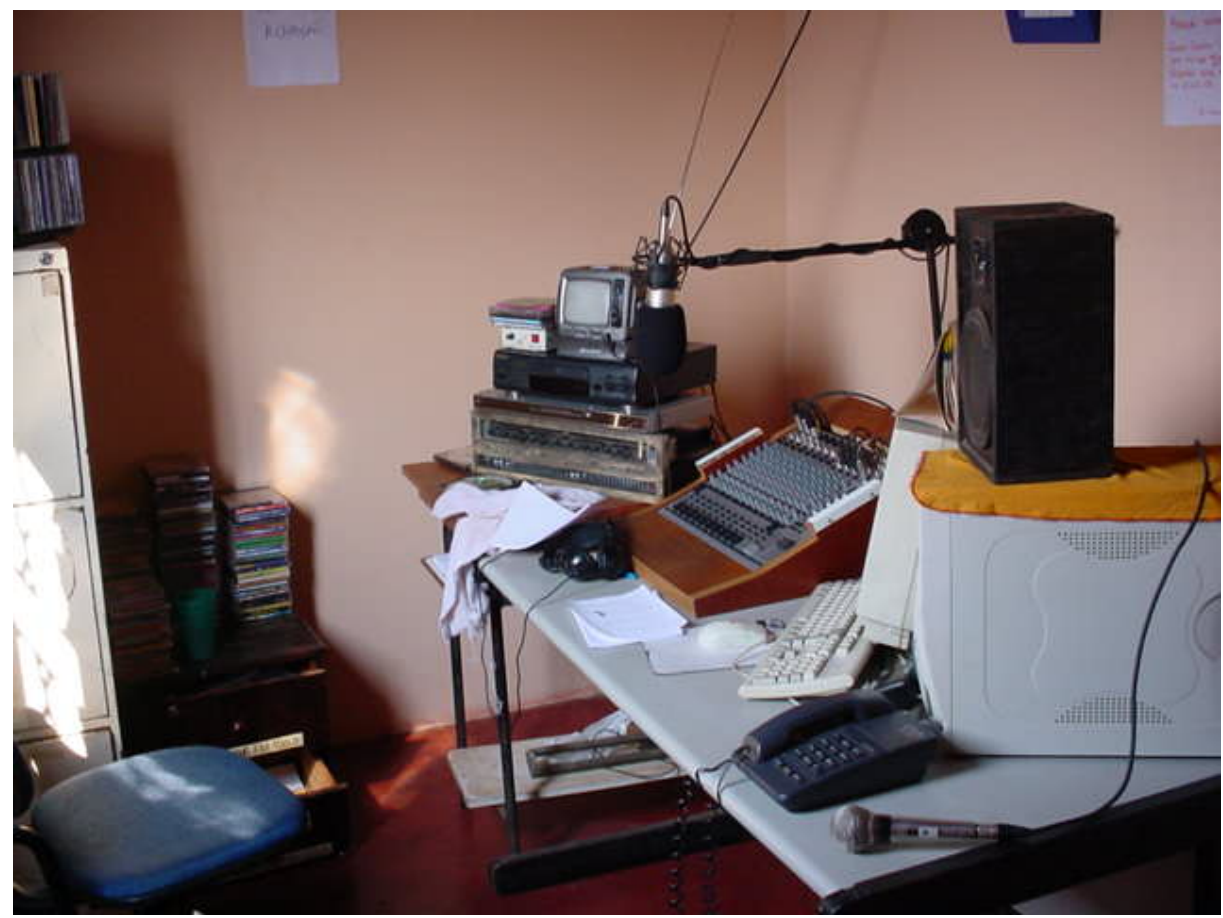

Figura 3.4 - Registro fotográfico do estúdio. 
Em geral, nos casos de emissoras de radiodifusão sem outorga para execução do serviço, uma vez constatada a infração, os agentes de fiscalização lacram o equipamento transmissor e o apreendem. Por se tratar de matéria de natureza penal, esse equipamento é normalmente entregue pela Anatel à custódia da Polícia Federal, que é responsável pelo processo de investigação e apontamento dos responsáveis. O trabalho de fiscalização da Anatel é técnico e tem como objetivo interromper o funcionamento das estações que operam em desacordo com a legislação ou a regulamentação, não se preocupando com os aspectos processuais do julgamento dos infratores.

\subsection{2 - Estações Rádio-Base do Serviço Móvel Pessoal}

Conforme analisado em detalhes no Item 5.6.1 do Capítulo 5 - Exposição Humana a Radiação Eletromagnética, as estações rádio-base (ERB) utilizadas na rede de suporte ao Serviço Móvel Pessoal (SMP), isto é, da chamada telefonia celular, são atualmente uma fonte de preocupação para a população em geral, com relação aos possíveis problemas de saúde decorrentes da exposição humana a campos eletromagnéticos de radiofreqüência. A Anatel tem visto esse assunto com bastante atenção, e freqüentemente são realizadas atividades de fiscalização para verificação do atendimento aos limites de exposição a que a população pode ser submetida. Invariavelmente, os dados obtidos nessas ocorrências mostram que os níveis de radiação eletromagnética de RF verificados na prática são bastante inferiores aos limites reconhecidos para exposições inofensivas à saúde humana.

Descreve-se a seguir uma atividade de fiscalização realizada no Setor de Indústria e Abastecimento (SIA), em Brasília-DF, pela Unidade Operacional da Anatel no Distrito Federal em julho de 2005. A ERB pertencia a uma operadora que utiliza o padrão GSM, e operava na faixa de $1.835 \mathrm{MHz}$ a $1.850 \mathrm{MHz}$. Portanto, os limites estabelecidos pelo Regulamento sobre Limitação da Exposição a Campos Elétricos, Magnéticos e Eletromagnéticos na faixa de Radiofreqüências entre $9 \mathrm{kHz}$ e $300 \mathrm{GHz}$, aprovado pela Resolução n. ${ }^{\circ} 303$, de 2 de julho de 2002, são de: $58,9 \mathrm{~V} / \mathrm{m}$ para intensidade de campo elétrico e $0,1585 \mathrm{~A} / \mathrm{m}$ para intensidade de campo magnético. 
A Figura 3.5 apresenta um registro fotográfico da região onde se encontra a ERB fiscalizada, com a indicação "torre". Os pontos onde foram realizadas medidas são também destacados nessa imagem. As Figuras 3.6 e 3.7 são fotografias obtidas a partir dos pontos 2 e 3, mostrando a torre da ERB. A Tabela 3.1 apresenta o resultado das medidas realizadas, apresentando-se o valor máximo obtido para cada campo em cada ponto, durante a atividade de fiscalização, confrontando esses valores com o estabelecido no Regulamento. Verifica-se que os campos eletromagnéticos medidos encontram-se em níveis bem abaixo dos limites regulamentares.

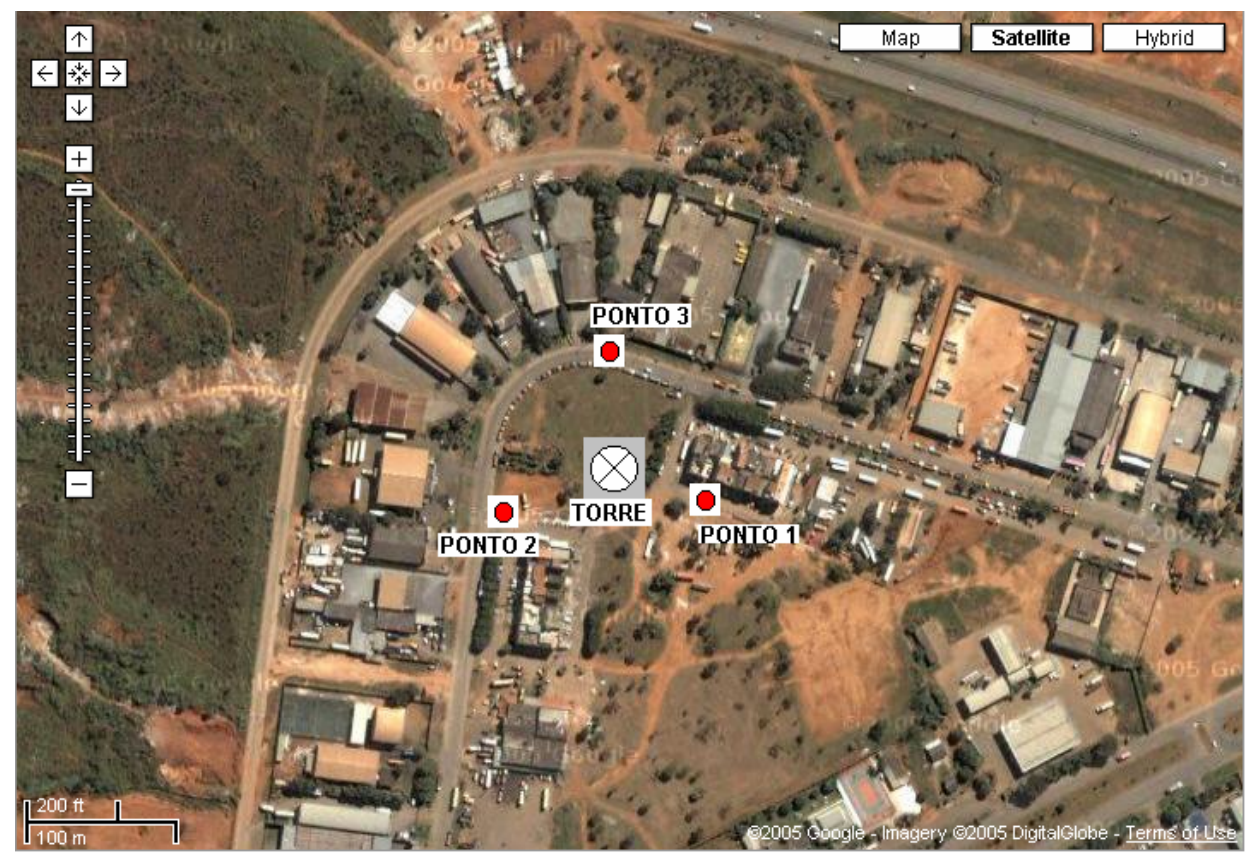

Figura 3.5 - Registro fotográfico da região onde foram realizadas as medições.

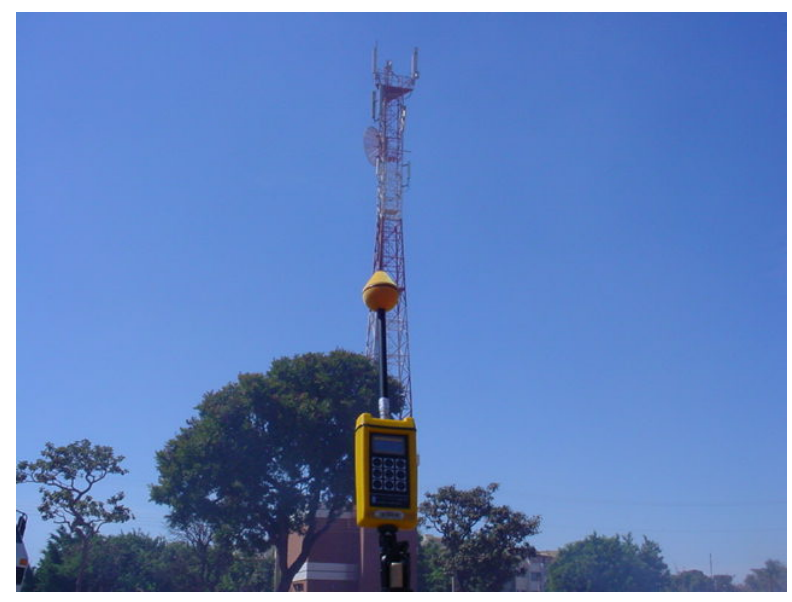

Figura 3.6 - Visão da torre no ponto 2.

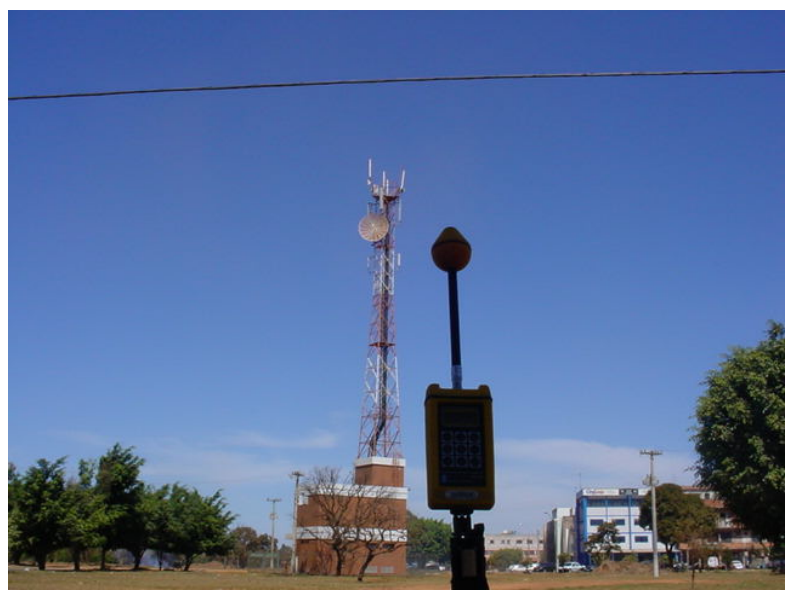

Figura 3.7 - Visão da torre no ponto 3. 
Tabela 3.1 - Medições realizadas na atividade de fiscalização.

\begin{tabular}{|c|c|c|}
\hline Referência & $\begin{array}{c}\text { Intensidade de Campo Elétrico } \\
(\mathrm{V} / \mathrm{m})-\text { valor máximo }\end{array}$ & $\begin{array}{c}\text { Intensidade de Campo Magnético } \\
(\mathrm{A} / \mathrm{m})-\text { valor máximo }\end{array}$ \\
\hline $\begin{array}{c}\text { limite estabelecido pela } \\
\text { Res. n. } 303 / 2002\end{array}$ & 58,9 & 0,1585 \\
\hline $\begin{array}{c}\text { Ponto 0: próximo à } \\
\text { torre }\end{array}$ & 0,64 & 0,0017 \\
\hline Ponto 1 & 0,93 & 0,0025 \\
\hline Ponto 2 & 0,65 & 0,0017 \\
\hline Ponto 3 & 1,03 & 0,0027 \\
\hline
\end{tabular}

Conforme observado nesse estudo de caso, as atividades de físcalização realizadas pela Anatel têm verificado que as entidades que funcionam com autorização (para serviços prestados no regime privado), concessão (para serviços prestados em regime público atualmente apenas o STFC) ou outorga (para o serviço de radiodifusão), em geral, operam em atendimento aos regulamentos que estabelecem parâmetros técnicos. Por sua vez, nas emissoras de radiodifusão sem outorga (as rádios "piratas"), normalmente verificam-se diversas irregularidades de ordem técnica, em especial relativas a limitação de potência, largura de faixa e ganho do sistema radiante.

Diante do exposto, observa-se a grande importância da atividade fiscalizatória que é de competência da agência reguladora. De forma a se garantir o uso do espectro de radiofreqüências por entidades autorizadas, faz-se necessário coibir de forma efetiva a utilização irregular por parte dos infratores. Cabe, nesse sentido, a célere atuação da Justiça a fim de punir os responsáveis, de forma a reprimir a atuação de novos interessados em infringir a regulamentação e impedir a reincidência. Entretanto, infelizmente, não se tem verificado essa atuação e, assim, muitos infratores que já foram fiscalizados pela Anatel voltam a praticar as mesmas irregularidades, uma vez que não sofreram as sanções aplicáveis. 


\section{CAPÍTULO 4}

\section{USO NÃO-LICENCIADO DE RADIOFREQÜÊNCIA}

\subsection{INTRODUÇÃO}

Via de regra, em virtude das características intrínsecas dos sistemas de comunicação que utilizam o espectro de radiofreqüências, os serviços de comunicação devem ser regulados, de forma a garantir o uso desse recurso escasso de maneira apropriada por todos os interessados. Entretanto, com o intuito de evitar sobrecarga de solicitações de licença nos órgãos reguladores, bem como para simplificar a utilização de RF por aplicações específicas, com baixas potências, criou-se a forma de uso não-licenciado do espectro. Nesse caso, são utilizados equipamentos de radiação restrita, ou seja, equipamentos de radiocomunicação cujo funcionamento dispensa a autorização para uso de radiofreqüência e o licenciamento da estação, pois a baixa potência empregada, em geral, não causa interferência em outros sistemas de RF. Incluem-se nessa modalidade, por exemplo, as aplicações de microfone sem fio, sistemas de telefone sem cordão, controles remotos de alarmes veiculares, sistemas de sonorização ambiental e equipamentos para redes locais sem fio.

Destaca-se, atualmente, o caso dos equipamentos que utilizam tecnologia de espalhamento espectral ou outras tecnologias de modulação digital e os sistemas de acesso sem fio em banda larga para redes locais. As faixas de frequiência utilizadas para essas aplicações são a banda ISM (Instrumentation, Scientific and Medical), que compreende três segmentos do espectro: $902 \mathrm{MHz}$ a $928 \mathrm{MHz}, 2.400 \mathrm{MHz}$ a $2.483,5 \mathrm{MHz}$ e $5.725 \mathrm{MHz}$ a $5.850 \mathrm{MHz}$; e a banda U-NII (Unlicensed National Information Infrastructure), que contém as faixas de freqüências entre $5.150 \mathrm{MHz}$ e $5.825 \mathrm{MHz}$

Cabe, contudo, esclarecer que essas não são faixas de freqüências "abandonadas" pelos entes reguladores, ou seja, são faixas reguladas, e há critérios que definem quando uma aplicação pode ser classificada como de uso não-licenciado. Nesse sentido, uma das exigências é que os equipamentos emissores de RF sejam submetidos a ensaios aplicáveis à certificação, de forma a comprovar a adequação desses produtos ao uso a que se destinam, tendo como premissa a não-interferência em outros sistemas. 
O uso não-licenciado de radiofreqüências, que no Brasil é regido pelo Regulamento sobre Equipamentos de Radiocomunicação de Radiação Restrita, aprovado pela Resolução n. ${ }^{\circ}$ 365 de 10 de maio de 2004, e as técnicas e tecnologias empregadas por esses equipamentos são o objeto de análise deste capítulo.

\subsection{CASO GERAL: USO LICENCIADO DE RF}

No caso geral, sendo o espectro de radiofreqüências um bem público escasso e regulado, seu uso deve ser oneroso. As estações de radiocomunicação, em geral, necessitam de licença de funcionamento, além da autorização para uso do espectro. Licenciamento, ou emissão da Licença para Funcionamento de Estação, é o ato administrativo que autoriza o início do funcionamento de uma estação individual, e está condicionado a prévia verificação, por parte da Anatel, do atendimento a toda regulamentação aplicável. Por sua vez, a Autorização de Uso de Radiofreqüências é o ato administrativo associado à concessão, permissão ou autorização para exploração de serviços de telecomunicações, que confere ao interessado, por prazo determinado, o direito de uso de radiofreqüências. A autorização de uso de RF está associada ao pagamento de preço público, conforme definido pelo Regulamento de Cobrança de Preço Público pelo Direito de Uso de Radiofreqüência, aprovado pela Resolução

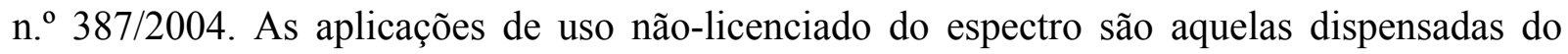
licenciamento da estação e de autorização para uso de RF.

\subsection{PRINCÍPIOS DO REGULAMENTO PARA USO NÃO-LICENCIADO DE RF}

Os equipamentos de radiação restrita operam em caráter secundário, isto é, não têm direito a proteção contra interferências prejudiciais provenientes de qualquer outra estação de radiocomunicação nem podem causar interferência em qualquer sistema operando em caráter primário. Essa informação deve ser colocada de forma visível no aparelho ou no manual de instruções. Nas faixas utilizadas por esses equipamentos, operam em caráter primário outros serviços de telecomunicações, como Móvel Celular, Auxiliar de Radiodifusão e Correlatos, e Especial de Radiodeterminação por Satélite.

A Tabela 4.1 lista as faixas de freqüências nas quais não é admitida a utilização de equipamentos de radiação restrita, pois os serviços que utilizam essas faixas não podem sofrer interferência por sua importância e, em alguns casos, seu caráter crítico, como por exemplo, o 
Serviço Móvel Marítimo e a Radionavegação Aeronáutica. A Tabela 4.2 apresenta os limites gerais de emissão que devem ser atendidos pelos equipamentos de radiação restrita. Ambas as tabelas foram extraídas do Regulamento sobre Equipamentos de Radiocomunicação de Radiação Restrita [10].

Esse regulamento traz também a previsão para condições específicas de uso, para as quais são estabelecidos limites de emissão alternativos aos das condições gerais, sendo menos restritivos, para equipamentos destinados a aplicações específicas e operando em determinadas faixas de freqüências, conforme resumidamente apresentado na Tabela 4.3. Essa tabela apresenta ainda, em alguns casos, uma breve descrição do equipamento e sua aplicação. Esses requisitos técnicos encontram-se definidos no Capítulo III do Regulamento e a primeira coluna da tabela apresenta a seção desse capítulo que corresponde a cada tipo de aplicação [11].

Tabela 4.1 - Faixas com restrições de uso de equipamentos de radiação restrita

\begin{tabular}{|c|c|c|c|}
\hline $\mathrm{MHz}$ & $\mathrm{MHz}$ & $\mathrm{MHz}$ & $\mathrm{GHz}$ \\
\hline $0,090-0,110$ & $13,36-13,41$ & $399,9-410$ & $5,35-5,46$ \\
$0,495-0,505$ & $16,42-16,423$ & $608-614$ & $6,65-6,6752$ \\
$2,1735-2,1905$ & $16,69475-16,69525$ & $952-1215$ & $8,025-8,5$ \\
$4,125-4,128$ & $16,80425-16,80475$ & $1300-1427$ & $9,0-9,2$ \\
$4,17725-4,17775$ & $21,87-21,924$ & $1435-1646,5$ & $9,3-9,5$ \\
$4,20725-4,20775$ & $23,2-23,35$ & $1660-1710$ & $10,6-11,7$ \\
$6,215-6,218$ & $25,5-25,67$ & $1718,8-1722,2$ & $12,2-12,7$ \\
$6,26775-6,26825$ & $37,5-38,25$ & $2200-2300$ & $13,25-13,4$ \\
$6,31175-6,31225$ & $73-74,6$ & $2483,5-2500$ & $14,47-14,5$ \\
$8,291-8,294$ & $74,8-75,2$ & $2655-2900$ & $15,35-16,2$ \\
$8,362-8,366$ & $108-138$ & $3260-3267$ & $20,2-21,26$ \\
$8,37625-8,38675$ & $149,9-150,05$ & $3332-3339$ & $22,01-23,12$ \\
$8,41425-8,41475$ & $156,52475-156,52525$ & $3345,8-3352,5$ & $23,6-24,0$ \\
$12,29-12,293$ & $156,7-156,9$ & $4200-4400$ & $31,2-31,8$ \\
$12,51975-12,52025$ & $242,95-243$ & $4800-5150$ & $36,43-36,5$ \\
$12,57675-12,57725$ & $322-335,4$ & & Acima de 38,6 \\
\hline
\end{tabular}

Tabela 4.2 - Limites gerais de emissão para equipamentos de radiação restrita

\begin{tabular}{|c|c|c|}
\hline $\begin{array}{c}\text { Faixa de freqüências } \\
(\mathrm{MHz}, \text { onde não especificado })\end{array}$ & $\begin{array}{c}\text { Intensidade de campo } \\
(\mu \mathrm{V} / \mathrm{m})\end{array}$ & $\begin{array}{c}\text { Distância da Medida } \\
(\mathrm{m})\end{array}$ \\
\hline $9-490 \mathrm{kHz}$ & $2.400 / \mathrm{f}(\mathrm{kHz})$ & 300 \\
\hline $490-1705 \mathrm{kHz}$ & $24.000 / \mathrm{f}(\mathrm{kHz})$ & 30 \\
\hline $1,705-30$ & 30 & 30 \\
\hline $30-88$ & 100 & 3 \\
\hline $88-216$ & 150 & 3 \\
\hline $216-960$ & 200 & 3 \\
\hline Acima de 960 & 500 & 3 \\
\hline
\end{tabular}


Tabela 4.3 - Faixas de freqüências de operação dos equipamentos

de radiocomunicação de radiação restrita para aplicações específicas

\begin{tabular}{|c|c|c|}
\hline $\begin{array}{l}\text { Seção } \\
\text { do } \\
\text { Regul. }\end{array}$ & $\begin{array}{c}\text { Equipamentos de Radiação Restrita para aplicações } \\
\text { específicas }\end{array}$ & $\begin{array}{l}\text { Freqüências } \\
\text { (MHz, onde não } \\
\text { especificado) }\end{array}$ \\
\hline I & $\begin{array}{l}\text { Dispositivos de Operação Periódica } \\
\text { (equipamento que opera de forma descontínua, como controles } \\
\text { remotos para acionamento de portões eletrônicos) }\end{array}$ & $\begin{array}{l}40,66-40,70 \\
\text { e acima de } 70\end{array}$ \\
\hline II & Equipamentos de Telemedição & $88-108$ \\
\hline II & Microfone sem Fio & $\begin{array}{c}54-72 \\
76-88 \\
88-108 \\
174-216 \\
470-608 \\
614-806\end{array}$ \\
\hline III & $\begin{array}{l}\text { Equipamentos de Telemedição Biomédica } \\
\text { (equipamento usado para transmitir medidas de fenômenos } \\
\text { biomédicos humanos ou animais, dentro de uma área restrita) }\end{array}$ & $\begin{array}{l}174-216 \\
512-566\end{array}$ \\
\hline III & Sistemas de Comunicações de Implantes Médicos (MICS) & $402-405$ \\
\hline IV & Equipamentos de Telemedição de Características de Material & $\begin{array}{c}890-907,5 \\
915-940\end{array}$ \\
\hline $\mathrm{V}$ & $\begin{array}{c}\text { Emissor-Sensor de Variação de Campo Eletromagnético } \\
\text { (dispositivo que estabelece um campo eletromagnético em sua } \\
\text { vizinhança e detecta mudanças naquele campo como resultante do } \\
\text { movimento dentro de sua faixa de atuação) }\end{array}$ & $\begin{array}{c}902-907,5 \\
915-928 \\
2435-2465 \\
5785-5815 \\
10500-10550 \\
24075-24175\end{array}$ \\
\hline $\mathrm{V}$ & $\begin{array}{l}\text { Sistema de Proteção de Perímetro } \\
\text { (emissor-sensor de variação de campo eletromagnético que } \\
\text { emprega linhas de transmissão de radiofreqüência como fonte de } \\
\text { radiação e que são instaladas de tal forma que permitem ao } \\
\text { sistema detectar movimentos dentro da área protegida) }\end{array}$ & $\begin{array}{l}40,66-40,70 \\
54-72 \\
76-88\end{array}$ \\
\hline $\mathrm{V}$ & $\begin{array}{c}\text { Sensor de Variação de Campo Eletromagnético (instalados em } \\
\text { veículos e utilizados como sistemas de radar de veículo) }\end{array}$ & $\begin{array}{l}46700-46900 \\
76000-77000 \\
\end{array}$ \\
\hline VI & $\begin{array}{c}\text { Dispositivo de Auxílio Auditivo } \\
\text { (aparelho usado para prover auxílio auditivo a pessoa ou grupo de } \\
\text { pessoas com deficiência) }\end{array}$ & $\begin{array}{l}72,0-73,0 \\
74,6-74,8 \\
75,2-76,0\end{array}$ \\
\hline VII & $\begin{array}{c}\text { Sistemas de Telefone sem Cordão } \\
\text { (sistema consistindo de dois transceptores, um sendo uma estação } \\
\text { base fixa que se conecta à rede telefônica pública comutada e a } \\
\text { outra uma unidade terminal móvel que se comunica diretamente } \\
\text { com a estação base) }\end{array}$ & $\begin{array}{c}43,7-47 \\
48,7-50 \\
902-907,5 \\
915-928\end{array}$ \\
\hline VIII & $\begin{array}{c}\text { Sistemas de Ramal sem Fio de CPCT } \\
\text { (sistema consistindo de uma estação base fixa que se conecta à } \\
\text { Central Privada de Comutação Telefônica - CPCT - e unidades } \\
\text { terminais móveis que se comunicam diretamente com a base) }\end{array}$ & $\begin{array}{c}864-868 \\
994-948 \\
1910-1930\end{array}$ \\
\hline
\end{tabular}




\begin{tabular}{|c|c|c|}
\hline IX & $\begin{array}{c}\text { Equipamentos Utilizando Tecnologia de Espalhamento Espectral } \\
\text { ou outras Tecnologias de Modulação Digital }\end{array}$ & $\begin{array}{c}902-907,5 \\
915-928 \\
2400-2483,5 \\
5725-5580 \\
\end{array}$ \\
\hline $\mathrm{X}$ & Sistemas de Acesso sem Fio em Banda Larga para Redes Locais & $\begin{array}{l}5150-5350 \\
5470-5725\end{array}$ \\
\hline XI & $\begin{array}{c}\text { Equipamento de Localização de Cabos } \\
\text { (dispositivo usado de forma não contínua com o objetivo de } \\
\text { localizar cabos, linhas, dutos e elementos ou estruturas similares } \\
\text { enterrados) }\end{array}$ & $9-490 \mathrm{kHz}$ \\
\hline XII & Sistemas de Identificação Automática de Veículos & $\begin{array}{c}2900-3260 \\
3267-3332 \\
3339-3345,8 \\
3358-3600\end{array}$ \\
\hline XIII & $\begin{array}{l}\text { Sistemas de Telecomando em geral } \\
\text { (Telecomando: transmissão de sinais de rádio para iniciar, } \\
\text { modificar ou terminar, à distância, funções de equipamento) }\end{array}$ & 26 e 27 \\
\hline XIII & $\begin{array}{c}\text { Sistemas de Telecomando (operados por portadores de Certificado } \\
\text { de Operador de Estações de Radioamador - COER) }\end{array}$ & 50 e 53 \\
\hline XIII & Sistemas de Telecomando para operação de aeromodelos & 72 \\
\hline XIII & Sistemas de Telecomando para operação de modelos de superfície & 75 \\
\hline XIV & $\begin{array}{c}\text { Equipamento de Radiocomunicação de Uso Geral } \\
\text { (unidade portátil com capacidade de transmissão bidirecional para } \\
\text { comunicação de voz - exemplo: walkie talk) }\end{array}$ & $\begin{array}{l}462,53-462,74 \\
467,53-467,74\end{array}$ \\
\hline $\mathrm{XV}$ & Sistemas Rádio de Baixa Potência Operando em $19 \mathrm{GHz}$ & $19165-19255$ \\
\hline XVI & Sistema de Sonorização Ambiental & $225-270$ \\
\hline XVII & $\begin{array}{c}\text { Equipamento Bloqueador de Sinais de Radiocomunicações (BSR) } \\
\text { (equipamento destinado a restringir o emprego de } \\
\text { radiofreqüências ou faixas de radiofreqüências específicas para } \\
\text { fins de comunicações) }\end{array}$ & - \\
\hline
\end{tabular}

\subsection{TECNOLOGIAS EMPREGADAS EM EQUIPAMENTOS PARA USO NÃO- LICENCIADO DE RF}

Atualmente, verifica-se uma acentuada proliferação do uso de redes locais sem fio, dentre as quais se destacam os padrões IEEE 802, especialmente Wi-Fi e Bluetooth. As principais técnicas implementadas por esses sistemas são o espalhamento espectral e a multiplexação ortogonal por divisão de freqüência (OFDM), que possuem, entre as suas características, a utilização racional e econômica do espectro, isto é, possuem elevada eficiência espectral. A seguir, apresenta-se uma visão geral dessas tecnologias. 


\subsubsection{Técnicas de Espalhamento Espectral}

Espalhamento espectral (spread spectrum) é a tecnologia na qual a energia média do sinal transmitido é espalhada sobre uma largura de faixa muito maior do que a largura de faixa que contém a informação [10]. Trata-se de uma técnica de codificação para transmissão digital de sinais desenvolvida originalmente para utilização militar, com o objetivo de transformar a informação transmitida em um sinal semelhante a um ruído, evitando monitoração pelos adversários. A técnica de espalhamento espectral consiste em codificar e modificar o sinal executando seu espalhamento no espectro de RF. Seu desenvolvimento viabilizou a transmissão de dados via rádio com alta confiabilidade e com taxas de transmissão cada vez maiores.

O emprego dessa técnica justifica-se, especialmente, para aplicações de uso nãolicenciado do espectro, uma vez que as faixas utilizadas apresentam grande quantidade de sinais interferentes. Nessa técnica, a banda de freqüências disponível é dividida em canais independentes e, ao longo do tempo, a freqüência de transmissão dos dados é alterada. Normalmente, se fala em espalhamento espectral com salto em freqüência (FHSS), quando as freqüências de transmissão são mudadas de um modo pseudo-aleatório (de acordo com um algoritmo); ou espalhamento espectral com seqüência direta (DSSS), quando a informação a ser transmitida é multiplicada por um sinal codificador, semelhante à técnica de múltiplo acesso por divisão de código (CDMA). De ambas as formas, consegue-se minimizar os efeitos causados por sinais externos, bem como evitar o problema do desvanecimento do sinal por múltiplos percursos (multipath fading), tornando a transmissão de dados mais robusta.

A Figura 4.1 apresenta, de forma simplificada, uma representação gráfica da técnica FHSS, mostrando seis saltos de freqüências de transmissão num intervalo de seis unidades de tempo. As freqüências utilizadas são, na seqüência apresentada, f5, f2, f6, f3, f1 e f4. A Figura 4.2 mostra a situação de transmissão e recepção, aplicando a duplexação por divisão de tempo (TDD), isto é, para cada período, alterna-se um tempo destinado para transmissão (em cinza f5, f6 e f1) e outro para recepção (em preto- f2, f3 e f4). 


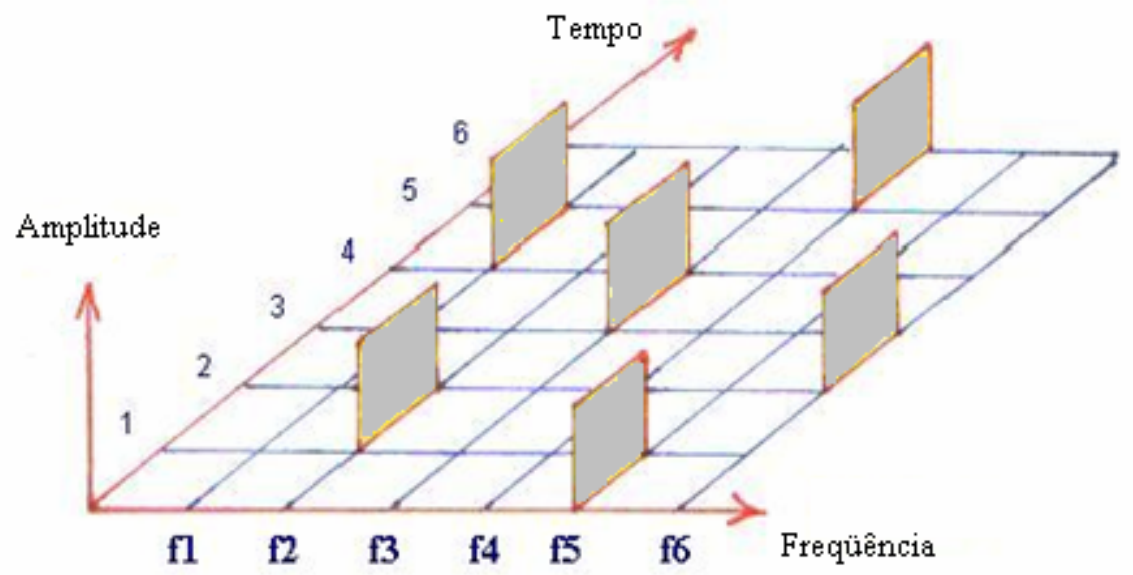

Figura 4.1 - Transmissão utilizando Espalhamento Espectral com Salto em Freqüência.

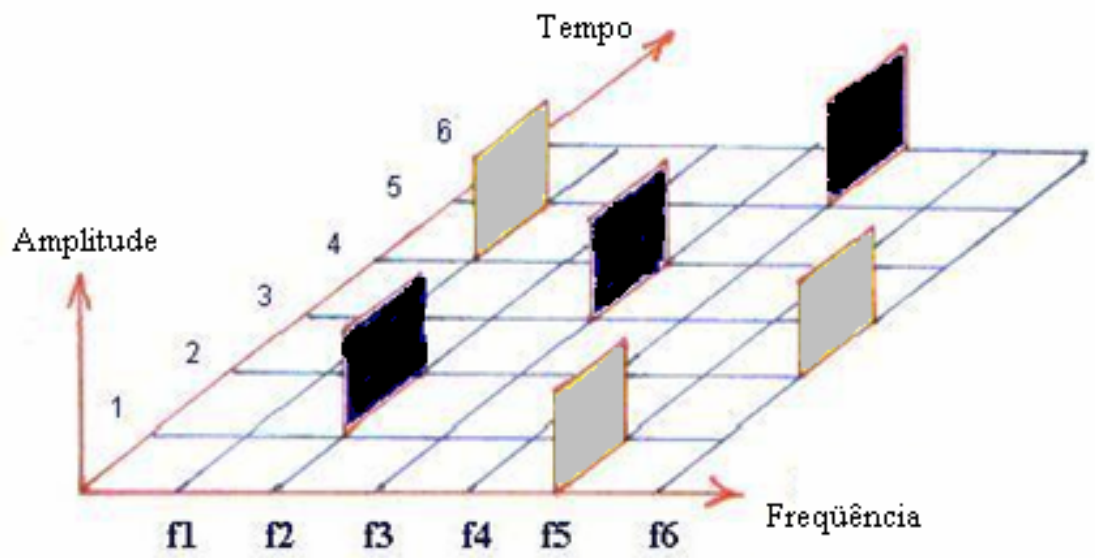

Figura 4.2 - Transmissão e Recepção utilizando Espalhamento Espectral com Salto em Freqüência.

\subsubsection{Multiplexação Ortogonal por Divisão de Freqüência}

Apesar de possuir em sua definição o termo multiplexação, a Orthogonal Frequency Division Multiplexing (OFDM) não é uma técnica de multiplexação como as conhecidas FDM (multiplexação por divisão de freqüência) ou TDM (por divisão de tempo), que caracterizamse por agregar sinais diferentes para serem transmitidos pelo mesmo meio. OFDM é um esquema de transmissão no qual um único sinal é transmitido por diversos canais de freqüências harmônicas (sub-portadoras), resultando em uma transmissão com maior capacidade e com menos problemas de interferência e distorção [12]. 
O princípio de operação desse esquema é a compressão de múltiplas sub-portadoras moduladas, reduzindo a largura de faixa requerida, mas mantendo-se a ortogonalidade, por meio de uma particular sobreposição espectral de sub-portadoras, de forma que não causem interferência entre si [13].

Em um sistema OFDM, para cada sub-portadora, os dados a serem enviados são codificados através de um esquema de modulação digital. Para a modulação independente de cada sub-portadora, geralmente é utilizado o esquema PSK (no qual a informação é representada por diferentes fases da portadora) ou o QAM (em que a informação é representada tanto pela variação tanto da fase quanto da amplitude). Dessa forma, tem-se um sinal $s(t)$, que pode ser representado genericamente pelos componentes $I(t)$ e $Q(t)$, conforme mostrado na Figura 4.3 [14]. As diversas possibilidades de valores que esse símbolo pode apresentar caracterizam a chamada "constelação" de um determinado esquema de modulação digital.

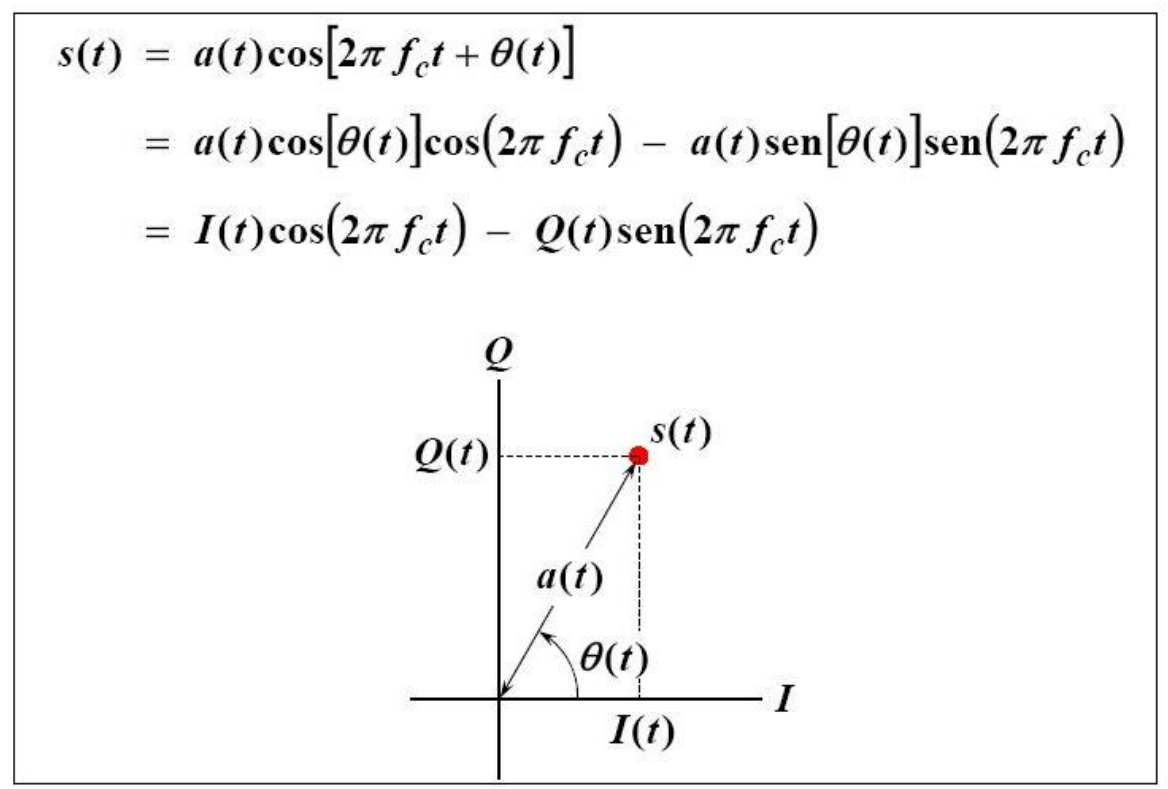

Figura 4.3 - Representação genérica de um símbolo digital no domínio do tempo.

No esquema OFDM, uma vez que essas variações de amplitude e fase para cada subportadora são conhecidas, elas são combinadas em um sinal composto, no domínio do tempo, usando a transforma inversa rápida de Fourier (IFFT) seguida de uma conversão paralelosérie. O resultado final desse processo é a conversão de bits individuais em um único sinal, no domínio do tempo, contendo uma coleção de sub-portadoras. Todas essas sub-portadoras 
juntas formam um símbolo OFDM que é então enviado pelo canal. No lado do receptor, a função inversa é realizada, ou seja, através da FFT, as sub-portadoras são separadas nas informações de amplitude e fase.

Uma ilustração desse processo é mostrada na Figura 4.4, para uma constelação 16QAM. De maneira mais detalhada, a Figura 4.5 mostra as etapas de geração do sinal OFDM no domínio do tempo, em que as sub-portadoras são moduladas, submetidas à operação transformada inversa de Fourier e convertidas em componentes $I(t)$ e $Q(t)$, que podem ser transmitidas através de uma portadora de radiofreqüência, conforme mostrado na Figura 4.6.[14].

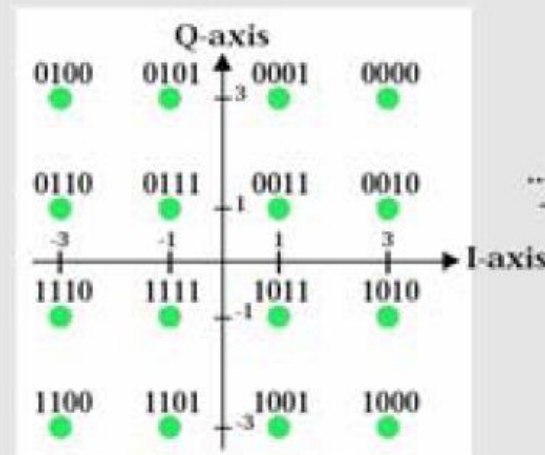

16QAM constellation (gray code constellation)

Figura 4.4 - Processo de geração de um sinal OFDM no domínio do tempo em banda base através da operação IFFT sobre um trem de bits.

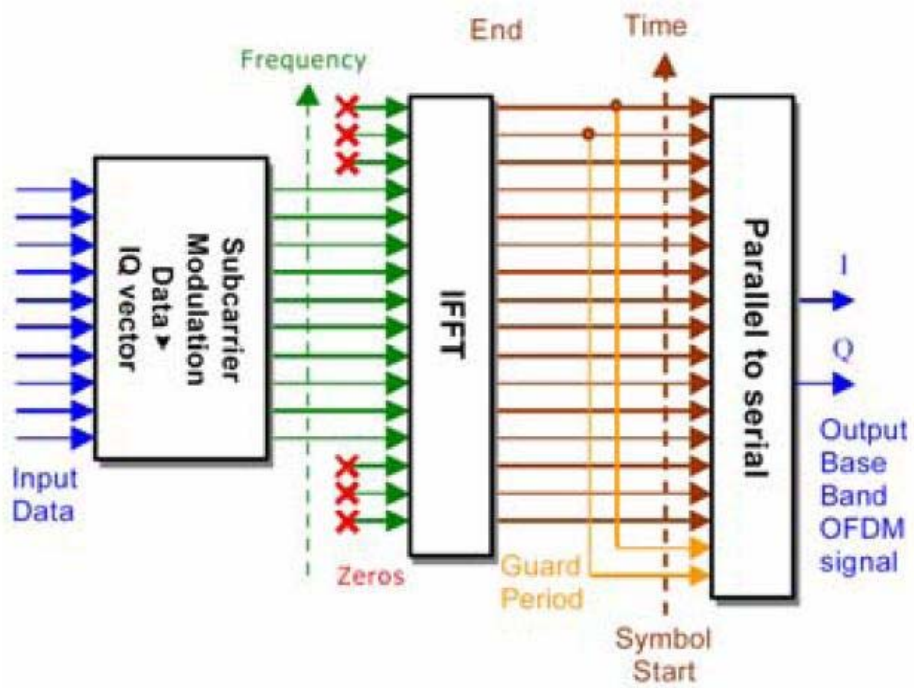

Figura 4.5 - Processo detalhado de geração de sinal OFDM no domínio do tempo em banda base através de um processamento da IFFT e da conversão paralelo-série. 


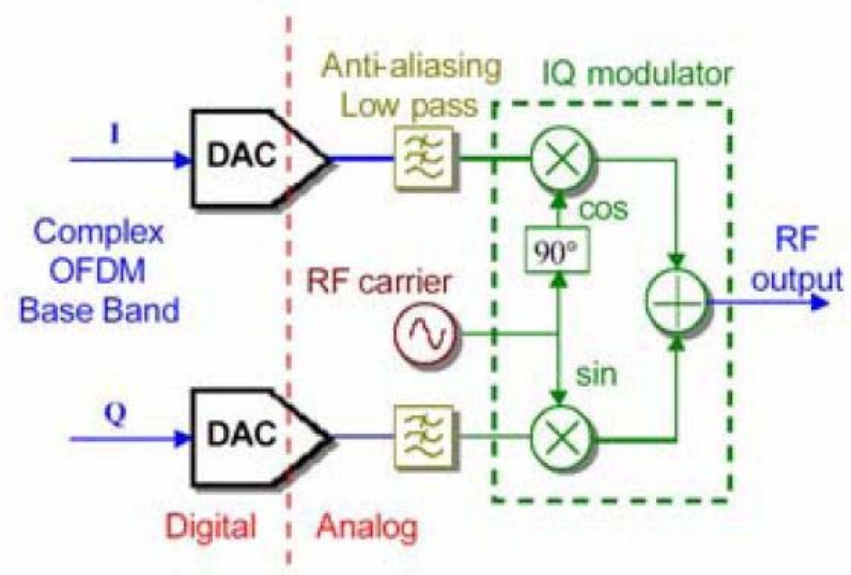

Figura 4.6 - Transmissão de um sinal OFDM através de uma portadora de RF.

Um dos princípios de funcionamento de um sistema OFDM é a ortogonalidade, propriedade que é garantida pela relação precisa entre as sub-portadoras que formam o símbolo OFDM. A Figura 4.7 mostra um exemplo de três sub-portadoras, todas com a mesma amplitude e fase de forma a simplificar a ilustração.

Pode-se observar que cada sub-portadora tem exatamente um número inteiro de ciclos em um dado intervalo de tempo T. Em outras palavras, a freqüência de cada sub-portadora é um múltiplo inteiro de uma freqüência fundamental ( $\mathrm{fl}=\mathrm{f} 0, \mathrm{f} 2=2 * \mathrm{f} 0, \mathrm{f} 3=3 * \mathrm{f} 0$, etc.). Verificase também que o número de ciclos no período de um símbolo de duas sub-portadoras adjacentes difere exatamente por um. Essas propriedades garantem a ortogonalidade entre as sub-portadoras e permitem, assim, que cada sub-portadora seja recebida e tenha as informações de seus bits demoduladas independentemente, livre que qualquer interferência de outras sub-portadoras presentes [15].

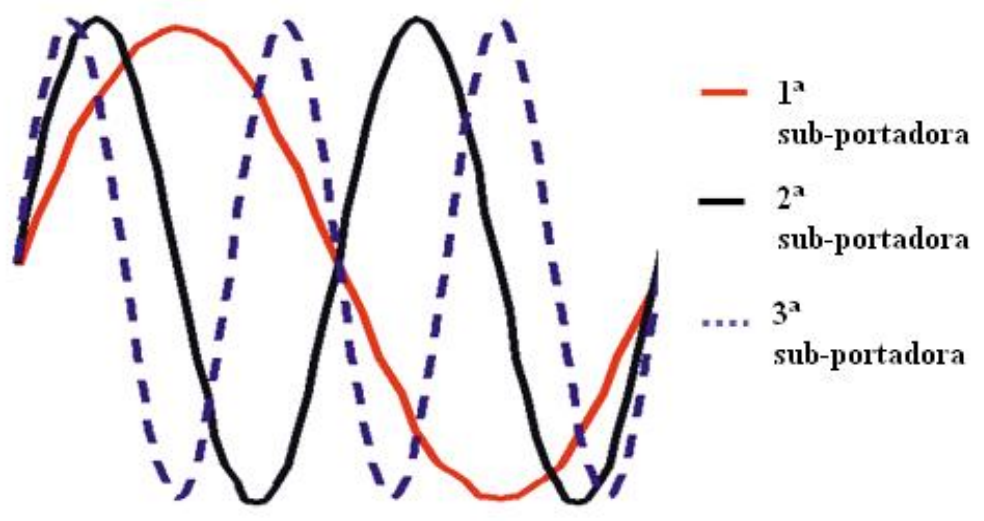

Figura 4.7 - Representação no domínio do tempo de três sub-portadoras ortogonais. 
Outra maneira de se verificar a ortogonalidade é mostrada na Figura 4.8, que é uma representação equivalente da Figura 4.7 no domínio da freqüência. $\mathrm{O}$ espectro de freqüências de cada sub-portadora é representado por uma função $\operatorname{sinc}(\mathrm{t})=[\operatorname{sen}(\mathrm{t})] / \mathrm{t}$, que tem como propriedade o fato de que seu valor de pico é verificado na freqüência central e possui nulos nas freqüências iguais a múltiplos inteiros dessa freqüência. Dessa forma, o receptor OFDM pode efetivamente demodular cada sub-portadora, pois, nas freqüências em que ocorre o pico de cada função sinc, a contribuição das funções sinc das demais sub-portadoras é nula.

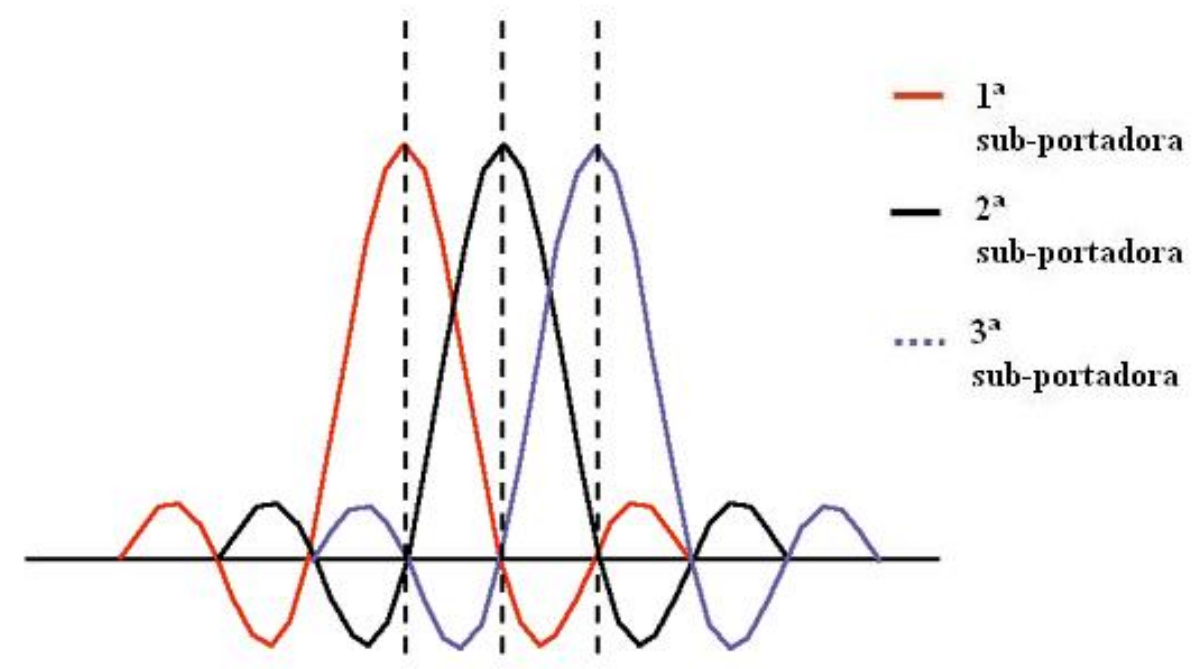

Figura 4.8 - Representação no domínio da freqüência de três sub-portadoras ortogonais.

Pode-se observar que, quando se utiliza a tradicional técnica de multiplexação FDM, as diversas portadoras, cada uma transportando um sinal distinto, são separadas por uma faixa de proteção (banda de guarda) para assegurar que não haja sobreposição, como mostrado na Figura 4.9. No caso do esquema OFDM, o princípio é semelhante, mas muito mais eficiente por dispor as sub-portadoras muito mais próximas, gerando uma sobreposição espectral, que produz uma economia significativa de banda relativamente à técnica FDM tradicional, como se verifica na Figura 4.10 [13].

Essa maior eficiência espectral é conseguida a custo de uma maior complexidade tecnológica para implementação dessa técnica, sendo necessária a operação de Transformada 
Discreta de Fourier para a demodulação do sinal. Essa é a razão pela qual esse esquema, proposto há algumas décadas, demorou algum tempo para popularizar-se.

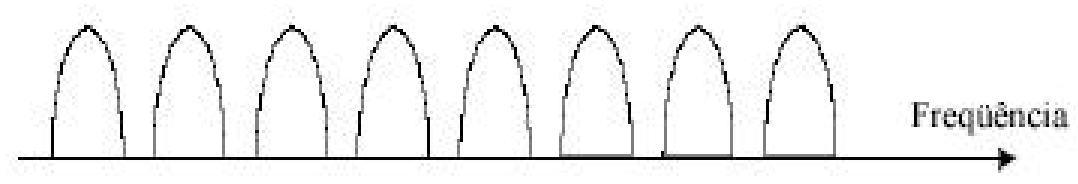

Figura 4.9 - Espectro de oito sub-portadoras associadas em FDM.

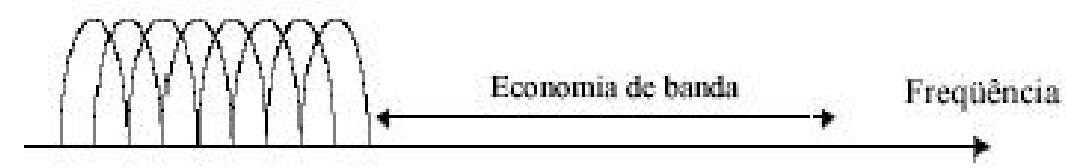

Figura 4.10 - Espectro de oito sub-portadoras associadas em OFDM, e indicação da banda de freqüências economizada em comparação com a técnica FDM.

Atualmente, o esquema de transmissão OFDM é largamente utilizado e também é proposto para diversas aplicações no futuro. Verifica-se seu uso em sistemas de radiodifusão digital e em redes sem fio, especialmente nos padrões Wi-Fi e WiMax, pois uma de suas principais vantagens (que incluem ainda elevada eficiência espectral e menor vulnerabilidade a interferência em RF) é a robustez ao desvanecimento multipercurso. Isto é, sistemas OFDM são menos afetados pela variação das características do canal, problema intrínseco aos sistemas de comunicações móveis.

\subsection{PADRÕES IEEE 802}

Passa-se agora a analisar, de forma resumida, alguns padrões empregados em equipamentos que aplicam técnicas de espalhamento espectral ou OFDM, e fazem uso nãolicenciado do espectro radioelétrico. Dependendo das características de cada sistema, especialmente de níveis de potência e de taxa de transmissão, esses equipamentos enquadramse na seção IX - Equipamentos Utilizando Tecnologia de Espalhamento Espectral ou outras Tecnologias de Modulação Digital, ou na seção X - Sistemas de Acesso sem Fio em Banda Larga para Redes Locais, do Regulamento sobre Equipamentos de Radiocomunicação de Radiação Restrita. 
Devido à necessidade de padronização entre dispositivos sem fio, o IEEE estabeleceu alguns padrões tecnológicos visando à transparência na comunicação sem fio de dispositivos de diversos fabricantes. Os padrões mais conhecidos atualmente são Bluetooth, para redes pessoais sem fio (WPAN - Wireless Personal Area Network); Wi-Fi, em redes locais (WLAN - Wireless Local Area Network) e WiMax, para redes metropolitanas (WMAN - Wireless Metropolitan Area Network). Apesar do padrão WiMax estar inserido entre os padrões IEEE 802, serão abordados no presente capítulo apenas os dois primeiros tipos de redes sem fio, uma vez que as redes metropolitanas normalmente utilizam níveis elevados de potência, pois a área que se deseja cobrir é da ordem de dezenas de quilômetros, e as faixas de freqüências utilizadas não são as faixas não-licenciadas. Por outro lado, as redes pessoais e locais fazem uso não-licenciado do espectro, e seus equipamentos são considerados de radiação restrita.

\subsubsection{Bluetooth - Padrão 802.15.1}

O padrão Bluetooth, que opera na faixa de freqüências de $2.400 \mathrm{MHz}$ a $2.483,5 \mathrm{MHz}$, é uma tecnologia aberta (royalty-free) para conexão sem fio a curta distância de dispositivos como telefones celulares, computadores, computadores de mão, fones de ouvido, microfones, teclados, eletrodomésticos etc. Trata-se de um exemplo de uma rede pessoal sem fio (Wireless Personal Area Network - WPAN), como os demais padrões IEEE 802.15.

O nome Bluetooth é uma referência ao Rei Harald Blåtand (em inglês, Harald Bluetooth), rei da Dinamarca no final do século X. Filho de Gorm, O Velho, Harald logrou, em seu reinado, controlar os reinos da Dinamarca e da Noruega. O objetivo da tecnologia Bluetooth é unificar dispositivos distintos por um padrão sem fio de curto alcance, como fez o rei Harald com esses dois reinos $[16,17]$.

Originalmente desenvolvido pela Ericsson, a proposta do Bluetooth é substituir as várias soluções proprietárias existentes para conexão destes dispositivos com uma solução padronizada que possa ser adotada a nível mundial. A taxa de transferência de dados alcançada com Bluetooth 1.0 é baixa, de até $1 \mathrm{Mbps}$, e sua área de cobertura também é limitada: dez metros, na maioria dos casos. Já o Bluetooth 2.0, consegue transferir dados a até $12 \mathrm{Mbps}$.

Através do Bluetooth, é possível fazer conexão a uma variedade de dispositivos de computação, de telecomunicações e eletrodomésticos de uma forma bastante simples, sem a 
necessidade de adquirir, carregar ou conectar cabos de ligação. A idéia é permitir a interligação desses dispositivos de uma forma automática e sem que o usuário necessite se preocupar com isso. Seu objetivo é facilitar as transmissões em tempo real de dados e voz, permitindo conectar quaisquer aparelhos eletrônicos, fixos ou móveis, que estejam de acordo com a tecnologia.

Alguns dos principais requisitos que nortearam o desenvolvimento do Bluetooth foram: baixo consumo de potência; baixo custo; cobertura pequena, tipicamente de 10 metros; e transmissão de voz e dados.

A comunicação entre os dispositivos Bluetooth é feita através do estabelecimento de um canal FHSS no qual, na média, os sinais são propagados sobre uma grande faixa de freqüência mas, a cada instante, somente uma pequena largura de banda é ocupada, evitando potenciais interferências na faixa ISM. Nesse padrão, foram definidas 79 portadoras espaçadas em $1 \mathrm{MHz}$. Essa distribuição de freqüências gera uma razoável largura de banda e uma boa imunidade à interferência. Portanto, existem 79 freqüências nas quais um dispositivo pode estar transmitindo em determinado instante de tempo. A seqüência particular de freqüências de um canal é estabelecida pelo dispositivo mestre (master), isto é, que iniciou a comunicação e, portanto, é o responsável pelo controle do canal. Todos os outros dispositivos participantes da rede são escravos (slaves) e devem se sincronizar ao mestre.

No domínio do tempo, um canal é dividido em slots de duração de $625 \mu \mathrm{s}$. De modo a simplificar a implementação, comunicações full-duplex são alcançadas aplicando-se TDD. Neste caso, os slots são utilizados de modo alternado para a transmissão e a para a recepção de pacotes. A Figura 4.11 ilustra a utilização de um canal FH/TDD com a tecnologia Bluetooth [16].

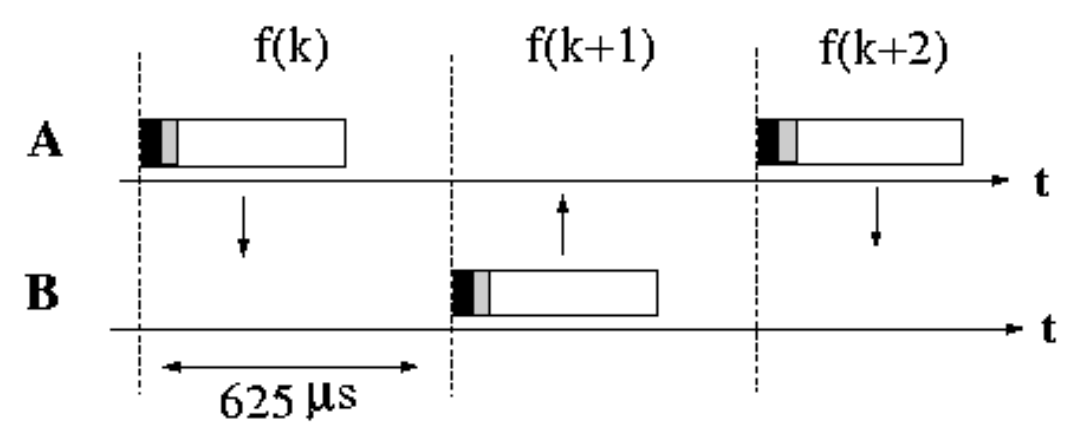

Figura 4.11 - Transmissão e recepção em um canal FH/TDD do Bluetooth. 


\subsubsection{Wi-Fi - Padrão 802.11}

O padrão 802.11, mais conhecido pela denominação comercial Wi-Fi (Wireless Fidelity - fidelidade sem fio), estabelece as características técnicas para redes locais sem fio (Wireless Local Area Network - WLAN). O Wi-Fi utiliza as bandas de freqüência nãolicenciadas ISM, e é dividido em diversos sub-padrões, sendo os principais descritos resumidamente a seguir [12].

- 802.11a: utiliza a faixa de freqüências de $5 \mathrm{GHz}$ e permite taxas de transferências de até $54 \mathrm{Mbps}$, utilizando o esquema OFDM. Seu alcance é de até 100 metros, mas torna-se deficitário quando comparado com as versões $11 \mathrm{~b}$ ou $11 \mathrm{~g}$, pois o custo de equipamentos compatíveis com esse protocolo é relativamente alto. A principal vantagem de trabalhar com o protocolo 11a é a sua maior estabilidade, já que há uma redução considerável de interferências no sinal, geralmente originárias de fornos de microondas, telefones sem fio e demais equipamentos de radiação restrita que utilizam a faixa de $2,4 \mathrm{GHz}$.

- 802.11b: atualmente é o sub-padrão Wi-Fi mais utilizado, seja em ambientes empresariais, comerciais ou residenciais. Como atrativos, o $802.11 \mathrm{~b}$ traz seu baixo custo de hardware e o fato de ter o maior parque instalado até o momento. Como desvantagens, há a possibilidade de interferências por dispositivos domésticos e a falta de uma segurança mais sofisticada. O protocolo 802.11b opera em 2,4 GHz e permite taxas de até 11 Mbps, utilizando a tecnologia DSSS. Seu alcance é de, aproximadamente, 300 metros.

- 802.11g: versão do protocolo 802.11 que mais cresce e ganha força. É esperado que a versão $11 \mathrm{~g}$ tome o lugar da $11 \mathrm{~b}$ a médio prazo, devido a sua taxa de transferência superior: 54 Mbps. Assim como a versão 11b, a $11 \mathrm{~g}$ também opera em 2,4 GHz, utilizando OFDM. Até o momento, os aparelhos $11 \mathrm{~g}$ têm o custo mais elevado em relação aos 11 b.

- 802.11n: forte concorrente do UWB (ultra wide band), o 802.11n, ou 802.11 Next Generation, promete ser o padrão sem fio para distribuição de mídia no futuro, pois 
oferecerá taxas mais altas de transmissão, da ordem de 100 Mbps, maior eficiência na propagação do sinal e ampla compatibilidade com demais protocolos.

- 802.11s: padrão em fase de proposição/homologação pelo IEEE, o 802.11s tem ênfase em redes auto-configuráveis, também conhecidas como "mesh networks", onde pontos de acesso (access points) podem comunicar-se entre si, permitindo uma maior cobertura e melhor roteamento através dos nós de rede.

\subsection{EXEMPLO DE UM EQUIPAMENTO DE RADIAÇÃO RESTRITA}

Para concluir o estudo do uso não-licenciado do espectro de radiofreqüências por equipamentos de radiação restrita, passa-se a analisar o exemplo de um computador de mão, modelo Tungsten E2, fabricado pela PalmOne, que utiliza a tecnologia Bluetooth, mostrado na Figura 4.12. A montagem da configuração de ensaio em uma câmara semi-anecóica é mostrada na Figura 4.13.

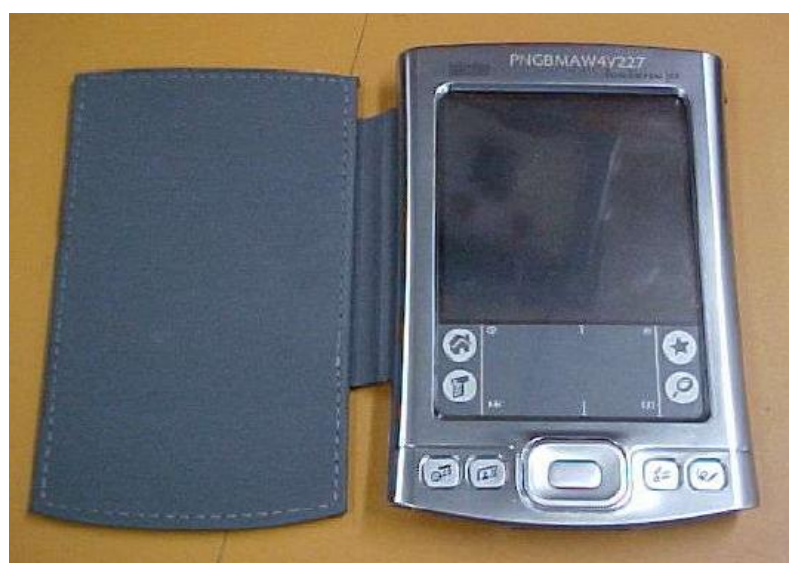

Figura 4.12 - Computador de mão modelo Tungsten E2 com tecnologia Bluetooth. 


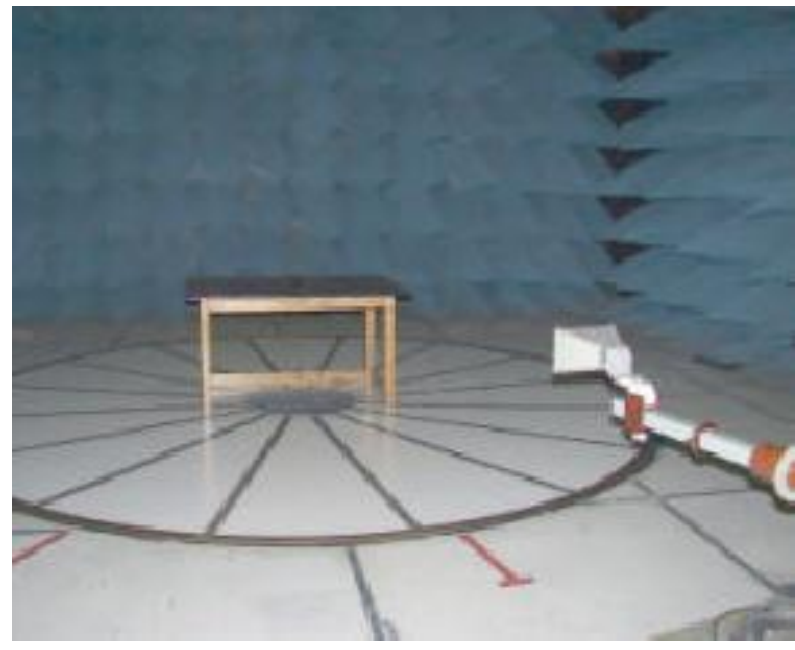

Figura 4.13 - Configuração de ensaio para o Tungsten E2.

Esse produto deve atender aos requisitos constantes na Seção IX - Equipamento Utilizando Tecnologia de Espalhamento Espectral ou outras Tecnologias de Modulação Digital, do Regulamento aprovado pela Resolução n. ${ }^{o}$ 365/2004. Uma ressalva importante contida nessa seção é que, para a faixa de $2.400 \mathrm{MHz}$ a 2.483,5 MHz, os equipamentos cuja potência e.i.r.p. seja maior do que $400 \mathrm{~mW}$, se utilizados em localidades com mais de 500 mil habitantes, não caracterizam uso não-licenciado de RF e, portanto, devem atender ao disposto na Resolução n. ${ }^{\circ}$ 397/2005, havendo a necessidade do licenciamento da estação e de autorização pela Anatel para uso do espectro.

Os principais requisitos técnicos contidos na Seção IX são listados a seguir e comparados com os ensaios realizados pelo laboratório NMi Brasil no modelo Tungsten E2, em Hortolândia-SP, em 03 de maio de 2005.

- Tecnologia empregada: na faixa de radiofreqüências de $2.400 \mathrm{MHz}$ a 2.483,5 MHz será admitido apenas o uso de Tecnologia de Espalhamento Espectral ou Tecnologia de Multiplexação Ortogonal por Divisão de Freqüência (OFDM) [10]. O produto utiliza tecnologia Bluetooth, que emprega espalhamento espectral com salto em freqüência (FHSS).

- Separação das portadoras: as freqüências portadoras dos canais de salto devem estar separadas por um mínimo de $25 \mathrm{kHz}$ ou pela largura de faixa do canal de salto de 20 
$d B$, devendo ser considerado o maior valor [10]. O resultado dos ensaios é apresentado na Tabela 4.4 e na Figura 4.14.

Tabela 4.4 - Resultado dos ensaios para o requisito de separação de portadoras

\begin{tabular}{|c|c|c|c|}
\hline $\begin{array}{c}\text { Freqüência fundamental } \\
(\mathrm{MHz})\end{array}$ & $\begin{array}{c}\text { Separação medida } \\
(\mathrm{MHz})\end{array}$ & $\begin{array}{c}\text { Separação especificada* } \\
(\mathrm{MHz})\end{array}$ & $\begin{array}{c}\text { Captura } \\
\text { de Tela }\end{array}$ \\
\hline 2440 & 0,987 & $\geq 0,918$ & Figura 4.9a \\
\hline 2442 & 0,993 & $\geq 0,918$ & Figura 4.9b \\
\hline
\end{tabular}

* O valor considerado para efeito de comparação é a largura de faixa medida a $20 \mathrm{~dB}$, que foi de $0,918 \mathrm{MHz}$, valor obtido através da média de três medidas realizadas.

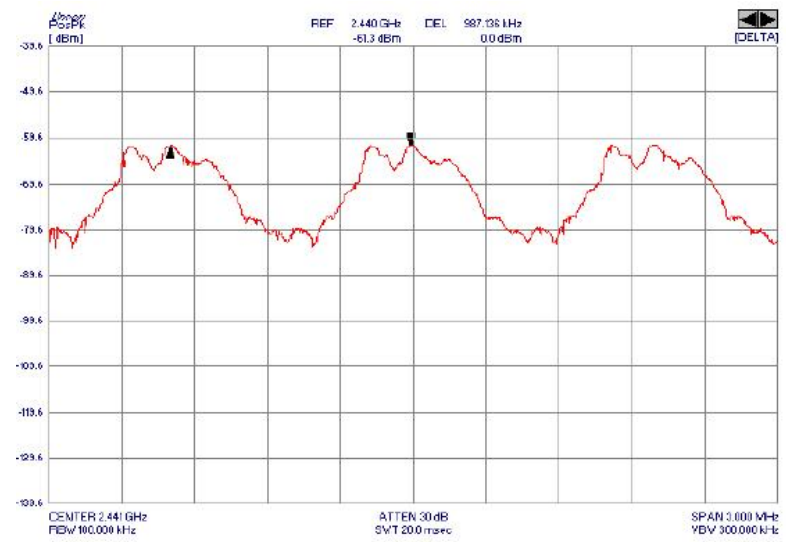

Figura 4.14 (a) - Separação de Canais de Salto medida entre canal inicial e central

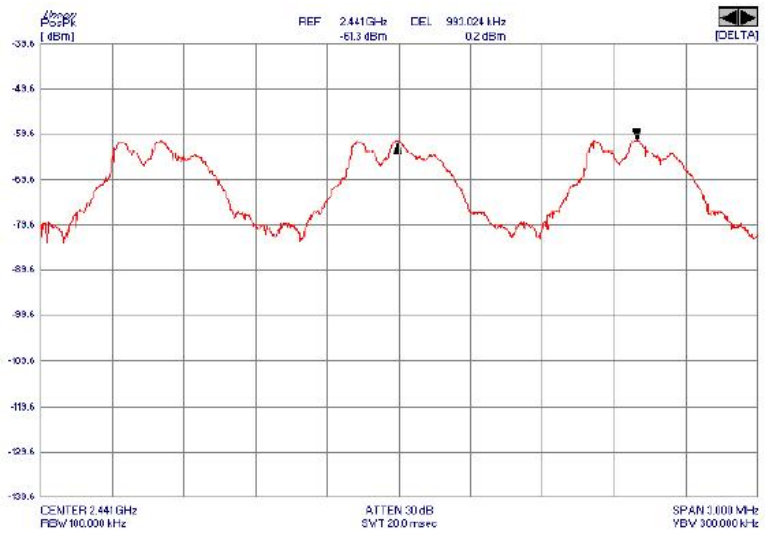

Figura 4.14 (b) - Separação de Canais de Salto medida entre canal central e final

- Tempo médio de ocupação: O tempo médio de ocupação de qualquer freqüência não deve ser superior a 0,4 segundos num intervalo de 0,4 segundos multiplicado pelo número de canais de salto utilizado [10]. O resultado é apresentado na Tabela 4.5 e na Figura 4.15.

Tabela 4.5 - Resultado dos ensaios para o requisito de tempo médio de ocupação

\begin{tabular}{|c|c|c|c|}
\hline $\begin{array}{c}\text { Número de } \\
\text { Canais }\end{array}$ & $\begin{array}{c}\text { Duração de um canal } \\
\text { (Figura 5.10a) }\end{array}$ & $\begin{array}{c}\text { Número de Repetições } \\
\text { (Figura 5.10b) }\end{array}$ & $\begin{array}{c}\text { Tempo médio de ocupação } \\
(0,42 \mathrm{~ms} \times \text { 330 repetições) }\end{array}$ \\
\hline 79 & $0,42 \mathrm{~ms}$ & 330 & $138,6 \mathrm{~ms}$ \\
\hline
\end{tabular}




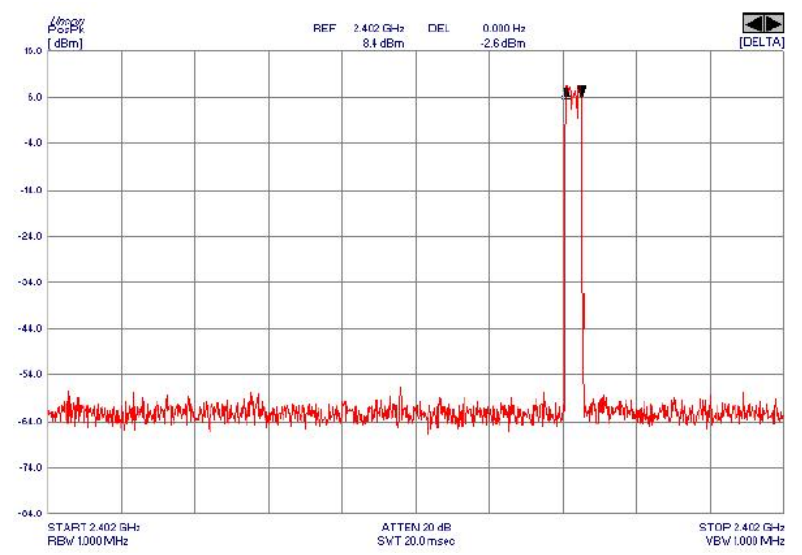

Figura 4.15 (a) - Tempo de ocupação de um canal de salto

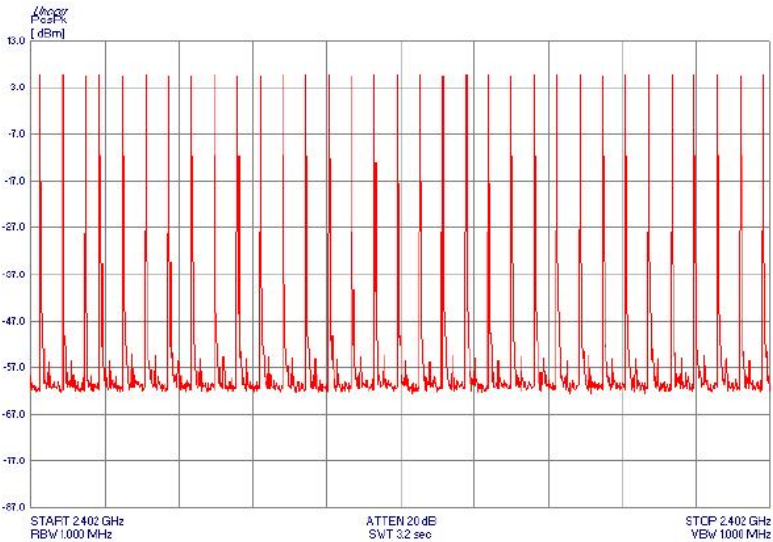

Figura 4.15 (b) - Número de repetições num intervalo de $0,4 \mathrm{~s}$

- Potência de pico máxima de saída: Para os sistemas que utilizam um número de freqüências de salto maior ou igual a 75, a potência de pico máxima de saída do transmissor é limitada a 1 watt [10]. O resultado é apresentado na Tabela 4.6.

Tabela 4.6 - Resultado dos ensaios para o requisito de potência de pico de saída

\begin{tabular}{|c|c|c|c|}
\hline Canal & $\begin{array}{c}\text { Freqüência fundamental } \\
(\mathrm{MHz})\end{array}$ & $\begin{array}{c}\text { Potência de pico de saída } \\
\text { medida }(\mathrm{mW})\end{array}$ & $\begin{array}{c}\text { Potência especificada } \\
(\mathrm{mW})\end{array}$ \\
\hline Inicial & 2402 & 1,18 & 1000 \\
\hline Central & 2441 & 1,21 & 1000 \\
\hline Final & 2480 & 0,76 & 1000 \\
\hline
\end{tabular}

- Potência de RF produzida fora da faixa: A potência de radiofreqüência produzida, em qualquer largura de faixa de $100 \mathrm{kHz}$ fora de qualquer uma das faixas na qual o sistema esteja operando, deve estar, no mínimo, 20 dB abaixo da potência máxima produzida num intervalo de $100 \mathrm{kHz}$ dentro da faixa de operação [10]. O resultado é apresentado na Tabela 4.7 e na Figura 4.16.

Tabela 4.7 - Resultado dos ensaios para o requisito de potência de RF fora da faixa

\begin{tabular}{|c|c|c|c|c|}
\hline Faixa de freqüência & $\begin{array}{c}P_{\text {fundamental }} \\
(\mathrm{dBm})\end{array}$ & $\begin{array}{l}P_{\text {espúrio }} \\
(\mathrm{dBm})\end{array}$ & $\begin{array}{c}\text { Diferença } \\
\text { calculada }(\mathrm{dB})\end{array}$ & $\begin{array}{c}\text { Diferença } \\
\text { especificada (dB) }\end{array}$ \\
\hline $30 \mathrm{MHz}$ a $1500 \mathrm{MHz}$ & $-63,80$ & $-106,80$ & 43,00 & \multirow{4}{*}{$\geq 20 \mathrm{~dB}$} \\
\hline $1500 \mathrm{MHz}$ a $2403 \mathrm{MHz}$ & $-67,30$ & $-96,10$ & 28,80 & \\
\hline $2479 \mathrm{MHz}$ a $2579 \mathrm{MHz}$ & $-64,20$ & $-99,90$ & 35,70 & \\
\hline $2,4 \mathrm{GHz}$ a $18,0 \mathrm{GHz}$ & $-69,60$ & $-101,90$ & 32,30 & \\
\hline
\end{tabular}




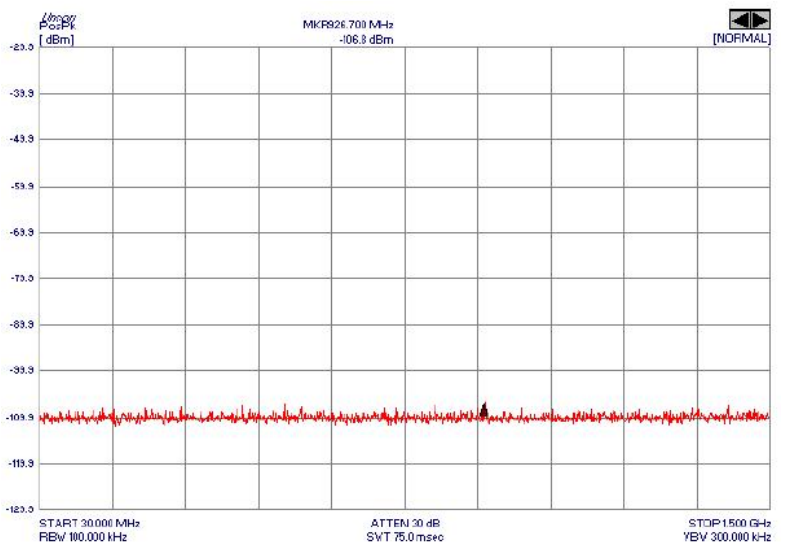

Figura 4.16 (a) - Potência de RF na faixa de $30 \mathrm{MHz}$ a $1500 \mathrm{MHz}$

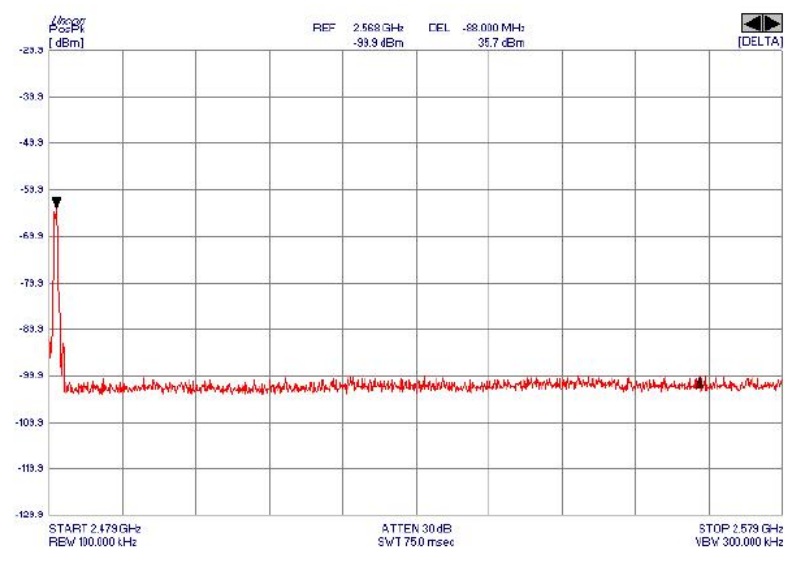

Figura 4.16 (c) - Potência de RF na faixa de $2479 \mathrm{MHz}$ a $2579 \mathrm{MHz}$

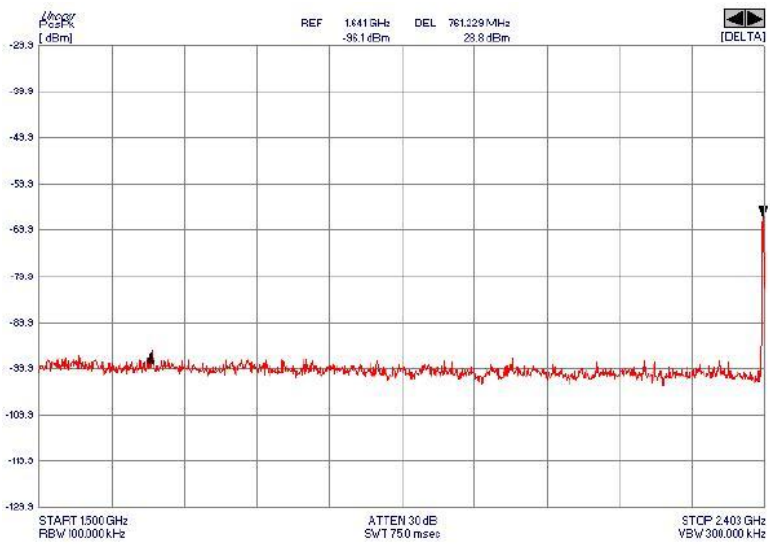

Figura 4.16 (b) - Potência de RF na faixa de $1500 \mathrm{MHz}$ a $2403 \mathrm{MHz}$

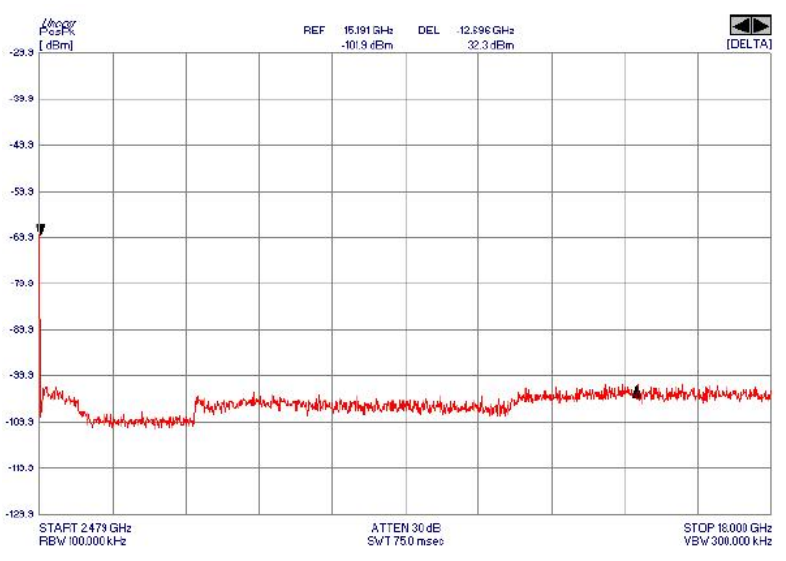

Figura 4.16 (d) - Potência de RF na faixa de $2,4 \mathrm{GHz}$ a $18,0 \mathrm{GHz}$

Verificou-se que o equipamento sob análise atendeu a todos os requisitos técnicos especificados pelo Regulamento sobre Equipamentos de Radiocomunicação de Radiação Restrita. A principal característica exigida, do ponto de vista de poluição do espectro radioelétrico, isto é, a potência de RF emitida, foi atendida com grande folga, estando o valor máximo quase $30 \mathrm{~dB}$ abaixo do limite determinado de $1 \mathrm{~W}$. 


\section{CAPÍTULO 5}

\section{EXPOSIÇÃO HUMANA A RADIAÇÃO ELETROMAGNÉTICA}

\subsection{INTRODUÇÃO}

A questão da exposição humana a campos eletromagnéticos e dos possíveis problemas de saúde decorrentes dessa exposição tem-se tornado uma das maiores preocupações dos organismos reguladores dos serviços que utilizam radiofreqüência. Com a expansão da rede de suporte ao Serviço Móvel Pessoal (SMP) e a instalação de estações rádio-base (ERB) cada vez mais próximas das residências, escolas e hospitais, atualmente essa questão tem recebido grande destaque nos meios de comunicação, embora, há muito, a população vem sendo exposta a diversos tipos de radiação eletromagnética, seja de fontes naturais, como a luz ou as radiações solares, seja de origem artificial, como as utilizadas em sistemas de comunicação.

No Brasil, a Anatel, no papel de regulador do espectro de radiofreqüências, é responsável pela determinação dos limites de radiação que as estações de radiocomunicação podem emitir. Para tanto, adota as recomendações da Comissão Internacional em Proteção contra Radiação Não-Ionizante (ICNIRP), ratificadas pela Organização Mundial de Saúde (OMC). Ressalte-se que, embora possam gerar efeitos sobre tecidos biológicos, as radiações em freqüências inferiores a $9 \mathrm{kHz}$, em especial da rede de energia elétrica, não estão sob o escopo de competência da Anatel, pois radiações abaixo desse limite não são classificadas como radiofreqüência.

Nesse estudo, é importante diferenciar as definições de "efeito biológico" e de "risco à saúde", pois essas expressões são muitas vezes erroneamente entendidas como sinônimos. Efeito biológico, para o ser humano, é apenas uma resposta a um estímulo externo; no caso, à energia das ondas eletromagnéticas. Esta resposta pode ou não representar um perigo. Risco à saúde é uma medida do perigo associado ao efeito biológico. Por exemplo, o efeito sobre o olho provocado pelas radiações na faixa do espectro eletromagnético referente à luz visível, correspondente a comprimentos de onda entre $400 \mathrm{~nm}$ e $700 \mathrm{~nm}$, é o princípio do sentido da visão. Tal efeito não apresenta risco, desde que a intensidade luminosa não ultrapasse um limiar considerado nocivo à saúde. O risco, neste caso, está relacionado com a intensidade da 
radiação. O exemplo da luz deixa claro que é errado associar perigo ou risco a todo efeito biológico da exposição a ondas de radiofreqüência. Efeitos ocorrem em qualquer faixa de freqüências, mas só constituem preocupação quando a radiação excede os limites de exposição $[18]$.

\subsection{RADIAÇÃO IONIZANTE E RADIAÇÃO NÃO-IONIZANTE}

As radiações eletromagnéticas ionizantes são aquelas que possuem freqüência acima de $3 \mathrm{PHz}\left(3 \times 10^{15} \mathrm{~Hz}\right)$, e recebem essa nomenclatura por possuírem energia suficiente para quebrar as ligações moleculares dos tecidos sobre os quais incidem. Por outro lado, as radiações abaixo desse limiar são denominadas não-ionizantes (RNI) e, entre elas, incluem-se as transmissões de radiofreqüência, situada na faixa de $9 \mathrm{kHz}$ a $3.000 \mathrm{GHz}$. A Figura 5.1 traz uma descrição gráfica de parte do espectro eletromagnético, distinguindo as freqüências que caracterizam as radiações como ionizantes ou não-ionizantes [19]. As ondas eletromagnéticas com maior freqüência já verificadas na natureza são as radiações gama $(\gamma)$, que possuem freqüência da ordem de $3 \times 10^{20} \mathrm{~Hz}$ e são oriundas de emissões radioativas.

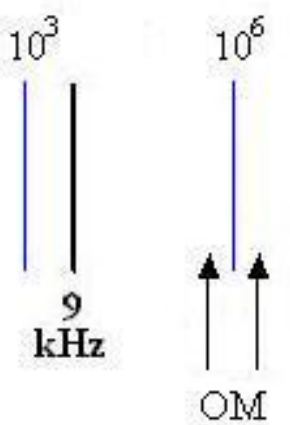

$\mathrm{OM}$

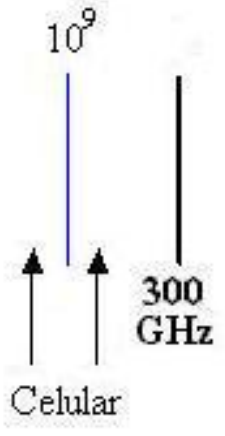

Celular
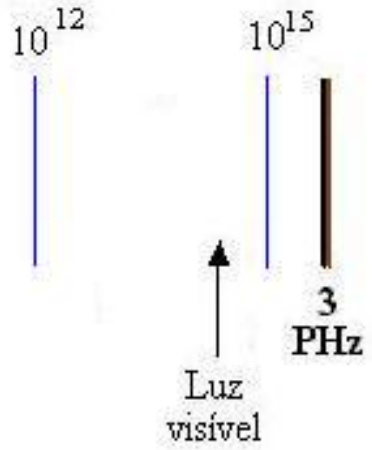
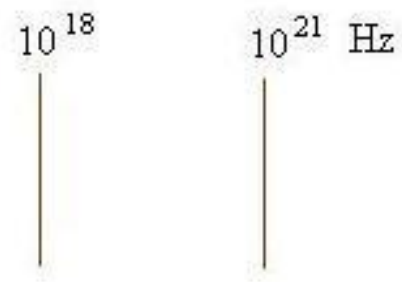

\section{Radiofreqüências}

Radição Não-Ionizante

\section{Radiação Ionizante}

Figura 5.1 - Divisão do espectro eletromagnético entre radiação ionizante e RNI.

A radiação ionizante pode produzir mudanças moleculares e levar a danos no tecido biológico, incluindo efeitos no DNA, constituinte do material genético humano. A energia concentrada das ondas eletromagnéticas ionizantes, como da luz ultravioleta e dos raios-X pode causar câncer, ao danificar a estrutura do DNA. Também pelo efeito molecular 
envolvido, os raios-X podem ser usados terapeuticamente para destruir células cancerosas [18].

Para a faixa de freqüências das emissões de RNI, o principal efeito conhecido é o aumento da temperatura do corpo (efeito térmico). Ao se propagar pelo corpo humano, as ondas eletromagnéticas têm parte de sua energia transformada em energia térmica, o que pode levar ao aquecimento. É este o princípio de funcionamento do forno de microondas [18]. Na determinação dos limites de exposição, o objetivo é estabelecer valores máximos de intensidade de campo e de densidade de potência tais que esse efeito térmico não incorra em risco à saúde humana. As entidades que estudam esse assunto verificaram que uma elevação em $1{ }^{\circ} \mathrm{C}$ na temperatura do tecido pode ocasionar risco para a saúde, gerando efeitos como alteração do metabolismo celular, fadiga e distúrbios do sono.

Para medida do efeito térmico da radiação eletromagnética no corpo humano, utiliza-se a Taxa de Absorção Específica (SAR - Specific Absortion Rate), que é a medida da densidade de potência por unidade de massa, normalmente medida em watts por quilograma (W/kg) de tecido biológico. A taxa de absorção de energia depende da densidade de potência da radiação eletromagnética e das características do tecido onde a radiação incide. Assim, a SAR quantifica a energia aplicada, sendo diretamente proporcional ao aumento local de temperatura [20]. Cabe ressaltar que os estudos levam em consideração o fato de que os diversos tecidos constituintes do corpo humano apresentam características elétricas e magnéticas distintas.

Em algumas faixas de freqüências, por facilidade de medição e modelamento, pode-se utilizar também a limitação para densidade superficial de corrente elétrica induzida por ondas de RF, medida normalmente em ampere por metro quadrado $\left(\mathrm{A} / \mathrm{m}^{2}\right.$ ou $\left.\mathrm{mA} / \mathrm{m}^{2}\right)$.

\subsubsection{Interação entre o Corpo Humano e a Radiação Não Ionizante}

Com respeito à absorção da energia pelo corpo humano, os campos eletromagnéticos de radiofreqüência (CEMRF) podem ser divididos em quatro faixas [21]:

- freqüências de aproximadamente $100 \mathrm{kHz}$ a $20 \mathrm{MHz}$, nas quais a absorção no tronco decresce rapidamente com a freqüência e pode ocorrer uma absorção significativa no pescoço e nas pernas; 
- freqüências de aproximadamente $20 \mathrm{MHz}$ a $300 \mathrm{MHz}$, nas quais pode ocorrer uma absorção relativamente alta no corpo todo, e até mesmo valores muito altos, se forem consideradas ressonâncias em partes do corpo (por exemplo, na cabeça);

- freqüências de aproximadamente $300 \mathrm{MHz}$ a $10 \mathrm{GHz}$, nas quais ocorre absorção local significativa e não-uniforme; e

- freqüências acima de $10 \mathrm{GHz}$, nas quais a absorção de energia ocorre principalmente na superfície do corpo.

A SAR média e a distribuição da SAR podem ser verificadas a partir de medidas em laboratório ou estimadas computacionalmente. Diversos aplicativos com esse objetivo implementam o Método das Diferenças Finitas no Domínio do Tempo (FDTD), uma técnica que tem sido largamente utilizada para solução de problemas de eletromagnetismo que não possuem solução analítica fechada. A Figura 5.2 traz o resultado gráfico de uma simulação do uso de um terminal móvel celular junto à cabeça, obtido através de um algoritmo que implementa o FDTD. As cores indicam o valor relativo da intensidade de campo elétrico [22].
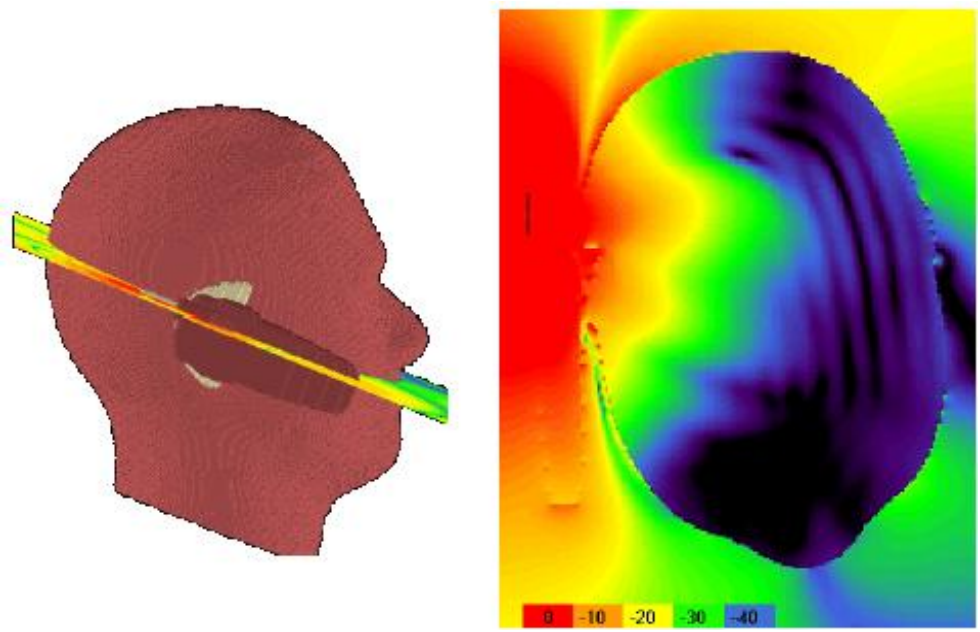

Figura 5.2 - Simulação computacional de exposição a radiação não-ionizante em uma cabeça humana, aplicando o método FDTD.

Em tecidos, a SAR é proporcional ao quadrado da intensidade do campo elétrico interno, e seu valor depende dos seguintes fatores [21]:

- parâmetros do campo incidente: freqüência, intensidade, polarização e configuração fonte-objeto (campo próximo ou distante); 
- características do corpo exposto: seu tamanho e geometria interna e externa e as propriedades dielétricas dos vários tecidos; e

- efeitos de aterramento e reflexão de outros objetos na região de campo próximo ao corpo exposto.

As recomendações de limites para exposição, em geral, estabelecem valores diferentes para exposição ocupacional e exposição da população em geral, sendo adotadas sempre restrições mais rigorosas para a exposição do público em geral. A população ocupacionalmente exposta compreende adultos que estão expostos a radiação eletromagnética em conseqüência de seu trabalho, desde que estejam cientes do potencial de exposição e possam exercer controle sobre sua permanência no local ou tomar medidas preventivas. Em contraste, o público em geral consiste de pessoas de todas as idades e estados de saúde e pode incluir grupos ou indivíduos particularmente suscetíveis, como crianças, idosos e doentes, além das pessoas expostas em função do seu trabalho, sem conhecimento dos riscos ou sem treinamento para tomar medidas preventivas [21, 23].

Diversas pesquisas permitiram concluir que $4 \mathrm{~W} / \mathrm{kg}$ é a intensidade de SAR que pode ser considerada perigosa, isto é, capaz de elevar a temperatura do tecido biológico humano em $1{ }^{\circ} \mathrm{C}$. Para a determinação dos limites recomendados de exposição, esse valor é dividido por um fator de segurança, que é igual a 10 para exposição ocupacional e 50 para população em geral, pelas recomendações da ICNIRP, adotadas no Brasil. Nesse caso, a restrição básica para exposição humana a campos eletromagnéticos, para média do corpo inteiro, é de $0,4 \mathrm{~W} / \mathrm{kg}$ para exposição ocupacional e de $0,08 \mathrm{~W} / \mathrm{kg}$ para a população em geral. Para absorção localizada, como na cabeça ou nos membros, os valores de limitação são distintos, conforme discutido no Item 5.5.

\subsection{O PRINCÍPIO DA PRECAUÇÃO}

Originário da política ambiental européia da década de 1970, o princípio da precaução é expresso em ditos como "melhor prevenir que remediar" e "erre no lado da cautela". Na prática, isto significa tomar medidas na direção de evitar possíveis danos ambientais ou para a saúde diante de evidência científica insuficiente. A Declaração do Rio, um dos documentos resultantes do processo preparatório que culminou com a realização da Conferência das Nações Unidas sobre Meio Ambiente e Desenvolvimento (CNUMAD), em 1992 no Rio de 
Janeiro, diz: "Onde existir ameaça de danos sérios ou irreversíveis, a falta de certeza científica plena não deve ser usada como razão para adiar medidas de custo-benefício eficientes para prevenir degradação ambiental" [24]. Neste caso, "certeza científica" pode ser interpretada tanto como um certo conhecimento do risco como um certo conhecimento de que as soluções propostos serão efetivas. O princípio da precaução foi originalmente pensado para a proteção contra riscos ambientais previsíveis sobre os quais poucos dados científicos estivessem disponíveis para sustentar uma política. A sua aplicação tem sido ampliada para o gerenciamento de riscos tecnológicos e para a saúde a respeito dos quais se dispõe de uma extensa quantidade de dados, apesar de inevitáveis omissões e inconsistências nas evidências, como é o caso da limitação da exposição humana a campos eletromagnéticos.

Os efeitos biológicos de campos eletromagnéticos não-ionizantes têm sido estudados por muitos anos, e uma imensa literatura existe sobre o assunto. Duas questões maiores (e cientificamente diferentes, com efeitos sobre o corpo humano bem distintos) são os riscos residenciais ou ocupacionais da exposição a campos elétricos e magnéticos em freqüência industrial (50-60 Hz) cuja análise, conforme mencionado, não faz parte do presente estudo, e a exposição pelo uso de telefones móveis (que operam tipicamente na faixa de $800 \mathrm{MHz}$ a 1.900 $\mathrm{MHz}$ ). Ambas as questões tem rapidamente chamado a atenção do público recentemente, apesar de extensa pesquisa científica não ter identificado claramente qualquer problema para a saúde humana, considerando os níveis normalmente encontrados de exposição.

A preocupação do público acerca de possíveis riscos para a saúde das tecnologias de comunicação sem fio teve início por uma notícia na TV americana, em 1993, segundo a qual uma mulher que tinha utilizado um telefone móvel morreu de câncer no cérebro. $\mathrm{O}$ marido dessa mulher acionou judicialmente a operadora, mas o processo foi arquivado por falta de provas. No entanto, a preocupação do público com estas alegações fez com que ressurgisse a pesquisa de assuntos biológicos de campos de radiofreqüência. Uma revisão da literatura sobre a questão, apresentada na conferência de Erice, Sicília, em novembro de 1999, identificou mais de 200 estudos, em andamento e recentemente completados, relacionados com possíveis danos para a saúde de campos de RF, incluindo vários estudos epidemiológicos, mais de 60 estudos com animais relacionados com câncer e 75 estudos com células. Estes estudos não identificaram uma conexão entre o uso de telefones celulares e câncer de cérebro ou qualquer outro efeito sobre a saúde por esta causa, além dos efeitos térmicos [25]. 
Tem-se observado que, sobre a questão da exposição a CEMRF, o governo e outros grupos de especialistas têm enviado mensagens diversas para o público. Por exemplo, em 2000, um comitê não-governamental na Inglaterra, o Comitê Stewart, emitiu um relatório concluindo que "a análise das evidências até o momento sugerem que radiação RF abaixo dos limites recomendados não causam efeitos adversos para a saúde da população em geral”. Mas "não é possível, no presente, dizer que exposição a radiação RF, mesmo abaixo das normas nacionais, é totalmente sem potenciais efeitos adversos sobre a saúde" [26]. Os níveis de exposição a RF verificados em diversos testes realizados no Brasil e no exterior são invariavelmente muito abaixo dos níveis reconhecidos como danosos [27]. Entretanto, o público continua preocupado e é freqüente a oposição de comunidades a novas estações rádiobase do SMP. Em resposta a esta preocupação, governos têm considerado adotar uma variedade de medidas baseadas no principio da precaução.

Se o "evitar por prudência" ou outras medidas de precaução têm benefícios políticos, elas também têm riscos: enviar para o público a mensagem errada que um dano realmente existe, caso contrário, por que o governo recomendaria tomar precauções? $\mathrm{O}$ público claramente entende os limites de exposição como um sinalizador para o dano, não importa quão seguros eles sejam considerados pelos estudiosos do assunto. Reduzir os limites de exposição como medida de "precaução" inevitavelmente significa que os níveis de exposição se tornarão mais próximos dos limites e, portanto, podem ser percebidos como mais perigosos para o público [25]. É importante ressaltar que a simples redução dos limites para exposição, normalmente feita como resposta à preocupação da sociedade, não é a essência do princípio da precaução, mas trata-se de apenas uma das medidas importantes propostas por esse princípio.

\subsection{RECOMENDAÇÕES INTERNACIONAIS}

Desde o início das comunicações via rádio, o efeito da radiação eletromagnética em seres humanos tem sido exaustivamente estudado. No final do século XIX, o médico e físico francês Jaques-Arsenè d'Arsonval conduziu os primeiros estudos relacionando ondas de rádio à saúde humana $[28,29]$. Atualmente, diversos organismos têm se dedicado a pesquisar os efeitos da radiação não-ionizante em tecidos humanos e a determinar os limites aos quais a população pode ser exposta sem incorrer em risco à saúde. As principais entidades padronizadoras nesse assunto e que têm suas recomendações aceitas internacionalmente são: 
Comissão Internacional em Proteção contra Radiação Não-Ionizante (ICNIRP), Conselho Nacional em Proteção e Medidas de Radiação (NCRP), Instituto Nacional Americano de Padrões (ANSI), e Instituto dos Engenheiros Eletricistas e Eletrônicos (IEEE). Além dessas, também têm se dedicado ao assunto a OMS, a União Internacional de Telecomunicações (UIT), ambos organismos integrantes das Nações Unidas, o Comitê Europeu para Padronização Eletrotécnica (CENELEC), a Comissão Federal de Comunicação dos Estados Unidos (FCC) e o Comitê Consultivo Internacional (IAC). A OMS, através do Projeto EMF (Eletromagnetic Fields - Campos Eletromagnéticos), realiza estudos em parceria com a ICNIRP.

A Anatel, órgão responsável pela regulação do espectro radioelétrico no Brasil, adotou integralmente as recomendações da ICNIRP, por reconhecer que as fundamentações técnicas apresentadas por esse organismo são as mais coerentes e adequadas. Pesa também o fato de que a OMS e o Conselho da Comunidade Européia reconhecem e ratificam as recomendações da ICNIRP, e de que essas recomendações são utilizadas em mais de trinta países, como Reino Unido, Alemanha, França, Espanha, Japão e Austrália [30].

Os Estados Unidos e o Canadá adotam as diretrizes FCC/ANSI/IEEE, que apresentam valores semelhantes para os limites de SAR média para o corpo todo, e limitações mais restritivas para absorção localizada na cabeça [27]. Por outro lado, a Suíça e a Itália, casos extremos da regulamentação de RNI, utilizam limitação 100 e 200 vezes, respectivamente, menor que os sugeridos pela ICNIRP [21]. Porém, nesses dois países verificou-se que essas limitações foram motivadas mais por interesses políticos do que por comprovação científica quanto aos riscos. Especialmente na Itália, o governo utilizou dinheiro público para subsidiar a substituição de grande parte da rede das operadoras de telefonia celular de forma a permitir o atendimento das novas limitações.

\subsection{REGULAMENTAÇÃO NO BRASIL}

No Brasil, até o fim da década de 1990, não havia um instrumento normativo que estabelecesse as limitações da exposição à radiação eletromagnética não-ionizante. Apenas algumas normas do Ministério do Trabalho se dedicavam a estabelecer padrões de segurança para pessoas expostas à radiação em virtude de seu trabalho. Em 1999, o Conselho Diretor da Anatel aprovou o documento Diretrizes para Limitação da Exposição a Campos Elétricos, 
Magnéticos e Eletromagnéticos Variáveis no Tempo (até $300 \mathrm{GHz}$ ), como referência provisória para limitação da exposição humana a CEMRF provenientes de estações transmissoras de serviços de telecomunicações, adotando na íntegra as orientações propostas pela ICNIRP. Essa publicação é, na verdade, a tradução do documento da ICNIRP Guidelines for Limiting Exposure to Time-Varying Electric, Magnetic, and Electromagnetic Fields (up to $300 \mathrm{GHz}$ ), realizada pelo Grupo de Trabalho de Efeitos Biológicos da Associação Brasileira de Compatibilidade Eletromagnética (Abricem).

Posteriormente, a Resolução n. 303 da Anatel, de 2 de julho de 2002, aprovou o Regulamento sobre Limitação da Exposição a Campos Elétricos, Magnéticos e Eletromagnéticos na Faixa de Radiofreqüências entre $9 \mathrm{kHz}$ e $3 \mathrm{GHz}$. Esse regulamento dispõe sobre o estabelecimento de limites de exposição e a definição de métodos de avaliação e de procedimentos que devem ser observados pelos prestadores de serviços de telecomunicação para a instalação e licenciamento de suas estações de radiocomunicação. A Tabela 5.1 reproduz a Tabela $\mathrm{V}$ do Regulamento, que estabelece as restrições básicas para exposição a campos eletromagnéticos.

Tabela 5.1 - Restrições básicas para limitação a campos eletromagnéticos de RF

\begin{tabular}{|l|c|c|c|c|c|}
\hline \multirow{2}{*}{$\begin{array}{c}\text { Características } \\
\text { de exposição }\end{array}$} & $\begin{array}{c}\text { Faixa de } \\
\text { Radiofreqüências }\end{array}$ & $\begin{array}{c}\text { Densidade de } \\
\text { corrente para } \\
\text { cabeça e tronco } \\
\left(\mathrm{mA} / \mathrm{m}^{2}\right) \\
(\mathrm{RMS})\end{array}$ & $\begin{array}{c}\text { SAR } \\
\text { média do } \\
\text { corpo inteiro } \\
(\mathrm{W} / \mathrm{kg})\end{array}$ & $\begin{array}{c}\text { SAR } \\
\text { localizada } \\
\text { (cabeça e } \\
\text { tronco) } \\
(\mathrm{W} / \mathrm{kg})\end{array}$ & $\begin{array}{c}\text { SAR } \\
\text { localizada } \\
\text { (membros) } \\
(\mathrm{W} / \mathrm{kg})\end{array}$ \\
\hline \multirow{2}{*}{$\begin{array}{l}\text { Exposição } \\
\text { Ocupacional }\end{array}$} & $9 \mathrm{kHz}$ a $100 \mathrm{kHz}$ & $f / 100$ & - & - & - \\
\cline { 2 - 6 } & $100 \mathrm{kHz}$ a $10 \mathrm{MHz}$ & $f / 100$ & 0,4 & 10 & 20 \\
\hline & $10 \mathrm{MHz}$ a $10 \mathrm{GHz}$ & - & 0,4 & 10 & 20 \\
\hline $\begin{array}{l}\text { Exposição da } \\
\text { população em } \\
\text { geral }\end{array}$ & $9 \mathrm{kHz}$ a $100 \mathrm{kHz}$ & $f / 500$ & - & - & - \\
\cline { 2 - 6 } & $100 \mathrm{kHz}$ a $10 \mathrm{MHz}$ & $f / 500$ & 0,08 & 2 & 4 \\
\cline { 2 - 6 } fé o valor da freqüência, em Hz. & $10 \mathrm{MHz}$ a $10 \mathrm{GHz}$ & - & 0,08 & 2 & 4 \\
\hline
\end{tabular}

A partir das restrições básicas de SAR e de densidade de corrente, é possível estabelecer limitações para intensidades de campo elétrico e magnético e para densidade de potência equivalentes, por serem grandezas mais facilmente mensuráveis em campo ou em laboratório. Essas limitações foram determinadas pela ICNIRP e apresentam-se no Regulamento em suas Tabelas I e II, reproduzidas nas Tabelas 5.2 e 5.3, que tratam de 
exposição ocupacional e da população em geral, respectivamente. O parâmetro $f$ é o valor da freqüência, cuja unidade deve ser a mesma indicada na coluna "Faixa de Radiofreqüências".

Tabela 5.2 - Limites para exposição ocupacional a campos eletromagnéticos de RF

\begin{tabular}{|c|c|c|c|}
\hline $\begin{array}{c}\text { Faixa de } \\
\text { Radiofreqüências }\end{array}$ & $\begin{array}{c}\text { Intensidade de Campo } \\
\mathrm{E}(\mathrm{V} / \mathrm{m})\end{array}$ & $\begin{array}{c}\text { Intensidade de Campo } \\
\mathrm{H}(\mathrm{V} / \mathrm{m})\end{array}$ & $\begin{array}{c}\text { Densidade de potência } \\
\text { da onda plana } \\
\text { equivalente, } \mathrm{S}_{\mathrm{eq}} \\
\left(\mathrm{W} / \mathrm{m}^{2}\right)\end{array}$ \\
\hline $9 \mathrm{kHz}$ a $65 \mathrm{kHz}$ & 610 & 24,4 & - \\
\hline $0,065 \mathrm{MHz}$ a $1 \mathrm{MHz}$ & 610 & $1,6 / f$ & - \\
\hline $1 \mathrm{MHz}$ a $10 \mathrm{MHz}$ & $610 / f$ & $1,6 / f$ & 10 \\
\hline $10 \mathrm{MHz}$ a $400 \mathrm{MHz}$ & 61 & 0,16 & $\mathrm{f} / 40$ \\
\hline $400 \mathrm{MHz}$ a $2000 \mathrm{MHz}$ & $3 f^{1 / 2}$ & $0,008 f^{1 / 2}$ & 50 \\
\hline $2 \mathrm{GHz}$ a $300 \mathrm{GHz}$ & 137 & 0,36 & \\
\hline
\end{tabular}

Tabela 5.3 - Limites para exposição da população em geral a campos eletromagnéticos de RF

\begin{tabular}{|c|c|c|c|}
\hline $\begin{array}{c}\text { Faixa de } \\
\text { Radiofreqüências }\end{array}$ & $\begin{array}{c}\text { Intensidade de Campo } \\
\mathrm{E}(\mathrm{V} / \mathrm{m})\end{array}$ & $\begin{array}{c}\text { Intensidade de Campo } \\
\mathrm{H}(\mathrm{V} / \mathrm{m})\end{array}$ & $\begin{array}{c}\text { Densidade de potência } \\
\text { da onda plana } \\
\text { equivalente, } \mathrm{S}_{\mathrm{eq}} \\
\left(\mathrm{W} / \mathrm{m}^{2}\right)\end{array}$ \\
\hline $9 \mathrm{kHz}$ a $65 \mathrm{kHz}$ & 87 & 5 & - \\
\hline $0,065 \mathrm{MHz}$ a $1 \mathrm{MHz}$ & 87 & $0,73 / f$ & - \\
\hline $1 \mathrm{MHz}$ a $10 \mathrm{MHz}$ & $87 / f$ & $0,73 / f$ & 2 \\
\hline $10 \mathrm{MHz}$ a $400 \mathrm{MHz}$ & 28 & 0,073 & $f / 200$ \\
\hline $400 \mathrm{MHz}$ a $2000 \mathrm{MHz}$ & $1,375 f^{1 / 2}$ & $0,0037 f^{1 / 2}$ & 10 \\
\hline $2 \mathrm{GHz}$ a $300 \mathrm{GHz}$ & 61 & 0,16 & - \\
\hline
\end{tabular}

O Regulamento sobre a Limitação da Exposição a CEMRF, aprovado pela Resolução n. ${ }^{\circ} 303 / 2002$, estabelece alguns aspectos a serem considerados na aplicação dos valores das Tabelas 5.2 e 5.3, dentre os quais destacam-se [23]:

- os limites de exposição estabelecidos se referem às médias espacial e temporal das grandezas indicadas;

- para radiofreqüências entre $100 \mathrm{kHz}$ e $10 \mathrm{GHz}$, o período de tempo a ser utilizado para cálculo da média temporal é de 6 minutos;

- para radiofreqüências acima de $10 \mathrm{GHz}$, o período de tempo a ser utilizado para cálculo da média temporal é de $68 / f^{1,05}$ minutos (f em GHz); 
- para radiofreqüências abaixo de $100 \mathrm{kHz}$, o conceito de média temporal não se aplica uma vez que, para estas radiofreqüências, os principais efeitos da exposição são os estímulos neurológicos instantâneos;

- no cálculo do valor médio da SAR localizada, deve ser utilizada uma massa de 10 gramas de tecido contíguo.

\subsubsection{Verificação do Atendimento aos Limites}

O Regulamento de Uso do Espectro de Radiofreqüências (RUE), aprovado pela

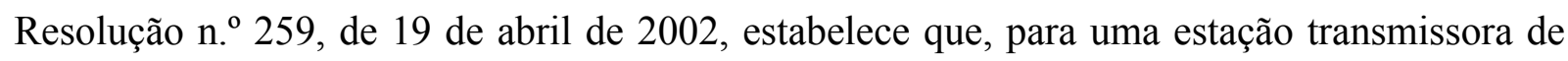
radiocomunicação obter autorização de funcionamento, essa estação deve atender aos limites de exposição ocupacional e da população em geral a campos eletromagnéticos [31]. Em conformidade com isso, o Regulamento sobre Limitação da Exposição a CEMRF, além de estabelecer os limites de exposição a campos eletromagnéticos, determina os procedimentos para verificação do atendimento a esses limites em estações transmissoras.

Permite-se realizar a avaliação por meio de análises teóricas ou por meio de medições diretas dos CEMRF, com a estação em funcionamento. Em locais onde é permitido o acesso de pessoas, quando os valores de CEMRF obtidos por meio de cálculos teóricos forem iguais ou superiores a $2 / 3$ (dois terços) dos limites de exposição estabelecidos para os campos elétricos ou magnéticos, será obrigatória a realização de medições. A avaliação deve ser efetuada por profissional habilitado (reconhecido pelo CREA como Engenheiro Eletrônico, Engenheiro Eletricista, Modalidade Eletrônica ou Engenheiro de Comunicação), o qual deve elaborar um Relatório de Conformidade. Esse Relatório deve ser mantido na estação para apresentação sempre que requisitado pela fiscalização da Anatel e conter a memória de cálculo dos campos eletromagnéticos produzidos pelas estações, utilizando-se modelos de propagação e resultados das medições utilizadas, e a indicação clara e conclusiva de que o funcionamento da estação, nas condições de sua avaliação, atende ao estabelecido no Regulamento sobre Limitação da Exposição a CEMRF. A partir do Relatório de Conformidade, o responsável pela estação (o proprietário ou seu representante legal) deve elaborar uma Declaração de Conformidade a ser apresentada à Anatel no momento do licenciamento. 
Para a avaliação da conformidade, são exigidos requisitos distintos entre terminais portáteis (isto é, estações cujas estruturas radiantes, quando em operação, ficam localizados a menos de $20 \mathrm{~cm}$ do corpo do usuário) e outros tipos de estações. Nos terminais portáteis, deve ser verificado o atendimento aos limites de SAR, Tabela 5.1, em laboratório, envolvendo a medida direta em um manequim que simula a cabeça ou o corpo humano e exibe as mesmas características de absorção do tecido humano. No caso de terminais do Serviço Móvel Especializado (SME) e do SMP, é exigido Relatório de Testes e Laudo Conclusivo referentes ao atendimento aos limites de SAR para a certificação e homologação desses terminais junto à Anatel.

Com relação aos demais tipos de estações (que não sejam os terminais portáteis), o Regulamento sobre Limitação da Exposição a CEMRF estabelece que a verificação do atendimento aos limites estabelecidos podem ser realizados por medições com a estação em funcionamento ou por cálculos teóricos. Para análise teórica, são apresentadas expressões para cálculo de distâncias mínimas a antenas de estações transmissoras para atendimento aos limites de exposição. Essas expressões são reproduzidas na Tabela 5.4 [23].

Tabela 5.4 - Expressões para cálculo de distâncias mínimas a antenas transmissoras para atendimento aos limites de exposição.

\begin{tabular}{|c|c|c|}
\hline Faixa de Radiofreqüências & Exposição da população em geral & Exposição ocupacional \\
\hline $1 \mathrm{MHz}$ a $10 \mathrm{MHz}$ & $r=0,10 \sqrt{\text { eirp } \times f}$ & $r=0,0144 \times f \times \sqrt{\text { eirp }}$ \\
\hline $10 \mathrm{MHz}$ a $400 \mathrm{MHz}$ & $r=0,319 \sqrt{\text { eirp }}$ & $r=0,143 \sqrt{\text { eirp }}$ \\
\hline $400 \mathrm{MHz}$ a $2 \mathrm{GHz}$ & $r=6,38 \sqrt{\text { eirp } \div f}$ & $r=2,92 \sqrt{\text { eirp } \div f}$ \\
\hline $2 \mathrm{GHz}$ a $300 \mathrm{GHz}$ & $r=0,143 \sqrt{\text { eirp }}$ & $r=0,0638 \sqrt{\text { eirp }}$ \\
\hline
\end{tabular}

$r$ é a distância mínima da antena, em metros;

$f$ é a freqüência, em $\mathrm{MHz}$;

eirp é a potência equivalente isotropicamente radiada na direção de maior ganho, em watt.

As expressões da Tabela 5.4 foram obtidas a partir do modelo de propagação para campo distante no espaço livre, considerando-se atenuação por espalhamento. Considera-se a potência radiada, o ganho da antena, a área da esfera de raio $r$ (distância do ponto de medição à antena) e um fator de reflexão, que levam em conta a possibilidade de que campos refletidos possam se adicionar em fase ao campo incidente direto. $\mathrm{O}$ valor de 2,56 para esse fator foi 
obtido por meio de diversos testes em campo. Dessa forma, a densidade de potência a uma distância $r$ da antena é dada por:

$$
S=\frac{e i r p \times 2,56}{4 \times \pi \times r^{2}}
$$

Para uma estação rádio-base do serviço móvel pessoal, por exemplo, o Regulamento sobre Condições de Uso de Radiofreqüências nas Faixas de $800 \mathrm{MHz}, 900 \mathrm{MHz}$ e $1.800 \mathrm{MHz}$ para prestação do Serviço Móvel Pessoal, aprovado pela Resolução n. ${ }^{\circ} 376$, de 2 de setembro de 2004, estabelece que a potência (erp), para operação nas subfaixas de radiofreqüências de $1.805 \mathrm{MHz}$ a $1.850 \mathrm{MHz}$ e de $1.870 \mathrm{MHz}$ a $1.880 \mathrm{MHz}$, deve estar limitada ao valor de 69 $\mathrm{dBm}$ [32]. Sabendo que a erp se relaciona com a eirp pelo fator linear 1,64, igual ao ganho do dipolo de meia onda, e que $69 \mathrm{dBm}$ é equivalente a $8 \mathrm{~kW}$, é possível verificar, aplicando a equação (5.1), que a distância mínima da antena para atendimento à limitação de densidade de potência nessa faixa de freqüências é de 16,9 m, obtida por

$$
r=\sqrt{\frac{e i r p \times 2,56}{4 \times \pi \times S}}=\sqrt{\frac{8000 \times 1,64 \times 2,56}{4 \times \pi \times(1880 / 200)}}=16,9 \mathrm{~m}
$$

Considerando que o fator de reflexão utilizado é extremo e que a maioria das estação rádio-base utiliza potência muito inferior à máxima permitida na regulamentação, especialmente nas regiões urbanas em que o reuso de freqüências é elevado, normalmente a distância necessária para que os níveis limites de exposição sejam atingidos são bem inferiores aos 16,9 m calculados. Portanto, mostra-se injustificável que algumas legislações municipais no Brasil exijam distâncias para instalação das ERBs de 50 m, 150 m ou 300 m, como se tem verificado em algumas localidades.

\subsubsection{Conflitos de Competência}

No Brasil, tem se verificado uma grande preocupação da população e de algumas autoridades quanto à limitação da exposição humana a RNI. Em resposta a essa preocupação, diversas leis municipais foram e estão sendo editadas buscando estabelecer limites para intensidade de campo, densidade de potência ou distância mínima entre as antenas e as regiões habitadas, especialmente para o SMP. O que se percebe é uma dificuldade em determinar qual é a competência de cada órgão no estabelecimento de normas e parâmetros técnicos. 
A Constituição Federal estabelece, em seu artigo 21, a competência da União para explorar os serviços de telecomunicação ou delegar essa exploração através de autorização, concessão ou permissão, controlando a prestação dos serviços por meio da agência reguladora, a Anatel. Adicionalmente, o artigo 22 da Constituição atribui privativamente à União a competência para legislar sobre telecomunicações. Por outro lado, os artigos 23 e 24 determinam que é competência comum da União, dos estados, do Distrito Federal e dos municípios cuidar da saúde pública e legislar sobre proteção e defesa da saúde [33], o que, em Direito Constitucional, se denomina competência concorrente. Assim, ao considerar o caso da limitação da exposição a RNI como assunto de saúde pública, pode parecer, a um observador leigo, que caberia também aos estados e municípios legislar sobre essa questão.

Porém a Lei Geral das Telecomunicações (LGT) prevê que à Anatel foi dada a competência para administrar o espectro de radiofreqüências e o uso de órbitas, expedindo as respectivas normas, fiscalizando e aplicando sanções. A LGT determina ainda que as prestadoras de serviços de telecomunicação devem atender às normas de engenharia e às leis municipais, estaduais ou do Distrito Federal relativas à construção civil e à instalação de cabos e equipamentos em logradouros públicos [9].

Assim, fica claro que embora caiba aos municípios legislar sobre o ordenamento territorial [33] local, o corpo técnico habilitado a regulamentar todas as questões referentes ao espectro de radiofreqüência, inclusive exposição humana a RNI, é a Anatel. Leis municipais podem, por exemplo, impedir a construção de torres para telefonia móvel celular em locais tombados como patrimônio histórico ou cultural, mas jamais deveriam estabelecer limites de intensidade de campo, densidade de potência ou distanciamento mínimo para antenas. Entretanto, infelizmente, isso tem se verificado em diversos locais do Brasil, como CriciúmaSC, Campinas-SP, Londrina-PR e Distrito Federal [28].

\subsection{A ATUAÇÃO DA ANATEL}

A Anatel tem demonstrado grande preocupação com a questão da exposição humana a campos eletromagnéticos não-ionizantes. Para esse propósito, acompanha o desenvolvimento das pesquisas científicas internacionais e, em especial, o andamento do Projeto EMF da Organização Mundial de Saúde. A Agência também se mantém informada sobre a 
normatização definida por órgãos como a ICNIRP, o ANSI e o CENELEC, que regularmente re-examinam suas diretrizes e publicam revisões quando necessário.

Adicionalmente, a Anatel exige que os limites por ela determinados sejam comprovadamente atendidos antes de autorizar o funcionamento de uma estação de radiocomunicação. Também os terminais portáteis do SME e do SMP só podem ser homologados mediante comprovação de conformidade com os limites de SAR.

Com relação à fiscalização, a Anatel vem constantemente realizando medidas em todo território nacional para verificação do atendimento aos limites de exposição a RNI. Invariavelmente, nos diversos locais em que as atividades de fiscalização foram realizadas, os valores encontrados de intensidade de campo ou densidade de potência encontram-se bem abaixo dos limites determinados. As exceções são algumas situações extremas, como nas proximidades de estações transmissoras de potência muito elevada, como emissoras de radiodifusão em ondas médias.

\subsubsection{Estudo de Caso}

Em maio de 2005, foi realizada uma atividade de fiscalização pelas Gerências de Fiscalização e de Engenharia do Espectro da Anatel, com uso do analisador de espectro da marca Rohde \& Schwarz, modelo FFH6, que opera na faixa de freqüências de $100 \mathrm{kHz}$ a 6 $\mathrm{GHz}$ com uma antena isotrópica, modelo Tri-axis probe - R\&S TAS-RS-44-03-18B, com banda de $30 \mathrm{MHz}$ a $3 \mathrm{GHz}$. O local escolhido foi a cobertura do Hotel Bonaparte no Setor Hoteleiro Sul (coordenadas 1547’42”S; 4753'19,6”W), pois este ponto dista 613 metros da Torre de TV de Brasília no Eixo Monumental, 326 metros da Torre Empresarial do Pátio Brasil Shopping e 164 metros do prédio da EMBRATEL, pontos onde existe uma grande concentração de antenas transmissoras. As Figuras 5.3 a 5.6 mostram fotografias obtidas no momento da fiscalização, de modo a caracterizar o ambiente. 


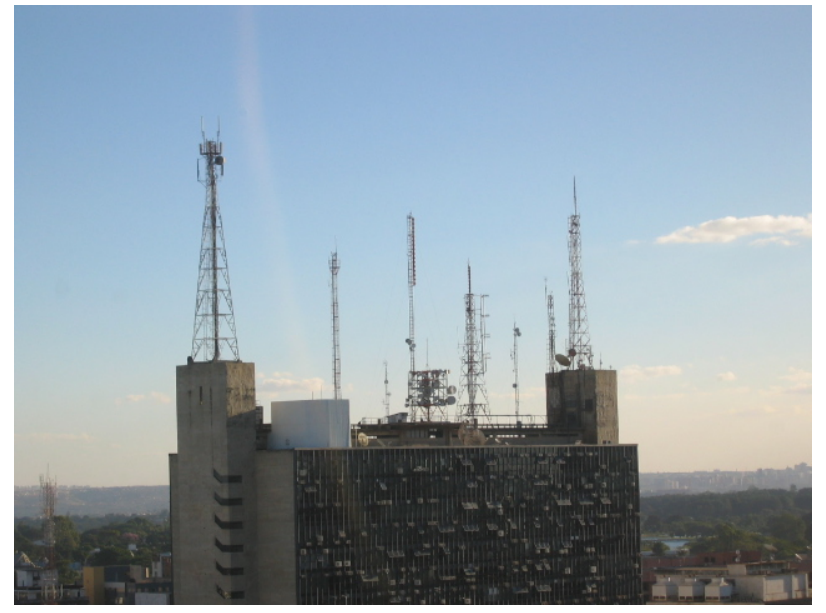

Figura 5.3 - Vista do local onde se realizou a fiscalização

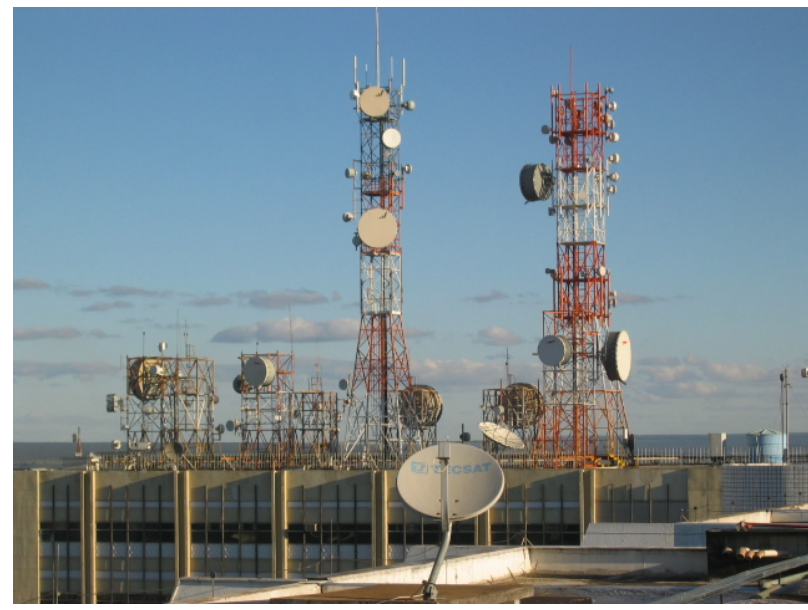

Figura 5.5 - Vista do local onde se realizou a fiscalização

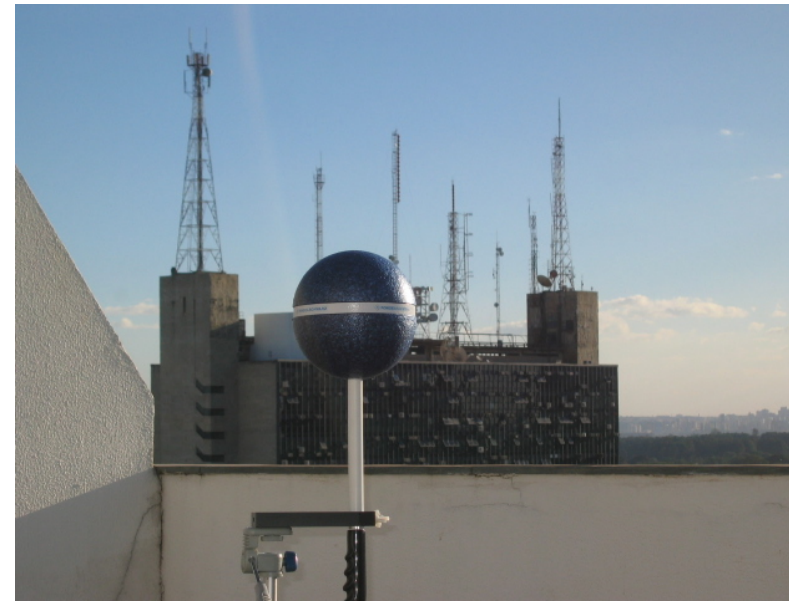

Figura 5.4 - Vista do local onde se realizou a fiscalização

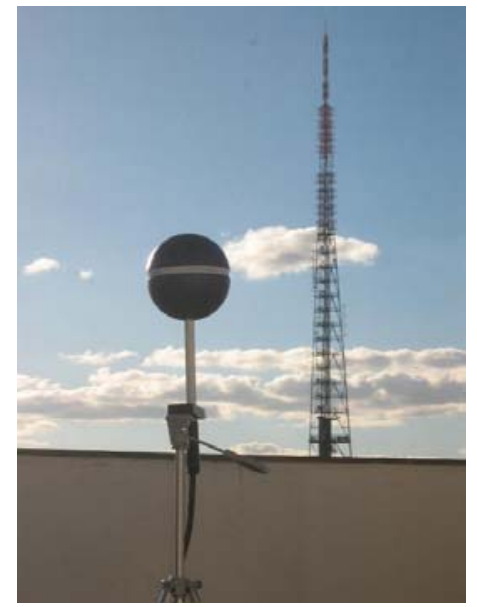

Figura 5.6 - Vista do local onde se realizou a fiscalização

Tabela 5.5 - Resultado da fiscalização sob estudo de caso e comparação com a regulamentação

\begin{tabular}{|c|c|c|c|}
\hline Descrição & $\begin{array}{l}\text { Faixa de } \\
\text { Freqüências } \\
(\mathrm{MHz})\end{array}$ & $\begin{array}{l}\text { Intensidade de campo } \\
\text { elétrico medido }(\mathrm{V} / \mathrm{m})\end{array}$ & $\begin{array}{l}\text { Limitação para intensidade de } \\
\text { campo elétrico }(\mathrm{V} / \mathrm{m}), \\
\text { segundo a Res. n. }{ }^{\circ} \text { 303/2002 }\end{array}$ \\
\hline TV em VHF & $76-88$ & 0,2939 & 28,0 \\
\hline Radiodifusão FM & $88-108$ & 7,1470 & 28,0 \\
\hline TV em VHF & $174-216$ & 0,0210 & 28,0 \\
\hline TV em UHF & $470-760$ & 0,1609 & 28,0 \\
\hline SMP 1 & $824-896$ & 0,6406 & 39,5 \\
\hline SMP 2 & $1710-1850$ & 0,1745 & 56,9 \\
\hline Faixa 1 & $1850-1870$ & 0,0186 & 59,1 \\
\hline Faixa 2 & $2500-3000$ & 0,0950 & 61,0 \\
\hline
\end{tabular}


Verifica-se que os valores encontrados estão muito abaixo dos limites estabelecidos na regulamentação aplicável. Esse fato tem sido verificado não só nesse caso específico sob estudo, mas na maioria das atividades fiscalizadoras em todo mundo [27]. Cabe destacar a faixa destinada à radiodifusão sonora em FM, de $88 \mathrm{MHz}$ a $108 \mathrm{MHz}$, pois a intensidade de campo elétrico nessa faixa foi muito maior que as demais medidas realizadas. É possível explicar essa ocorrência devido às antenas transmissoras de radiodifusão presentes nos Setores de Rádio e TV Sul e Norte e na Torre de TV.

Diante do exposto, não há motivo para o receio que tem se verificado entre a população com relação à exposição a RNI. A Anatel, como órgão regulador do espectro de radiofreqüência no Brasil, expediu regulamento estabelecendo os limites que são considerados seguros, com base no conhecimento científico atual, alinhado com orientações adotadas em diversos países, em especial na Comunidade Européia, e reconhecido pela Organização Mundial de Saúde. As atividades de fisscalização têm confirmado que os limites existentes são atendidos com folga e portanto, à luz do atual conhecimento científico sobre a interação entre campos eletromagnéticos de RF e tecidos biológicos humanos, não há risco potencial para a saúde da população. 


\section{CAPÍTULO 6}

\section{CERTIFICAÇÃO E HOMOLOGAÇÃO DE PRODUTOS PARA TELECOMUNICAÇÃO}

\subsection{INTRODUÇÃO}

No estudo da regulação de telecomunicação, uma questão eminente é a Certificação. Esse procedimento permite verificar se os produtos comercializados e utilizados no País atendem a legislação em vigor, assegurando o cumprimento dos padrões de qualidade e dos requisitos de segurança. Neste capítulo é realizada uma análise do modelo vigente no Brasil desde a edição do Regulamento para Certificação e Homologação de Produtos para Telecomunicação, aprovado pela Resolução n. ${ }^{\circ}$ 242, de 30 de novembro de 2000.

\subsection{PRODUTOS PARA TELECOMUNICAÇÃO}

Todos os equipamentos que fazem uso do espectro de RF como emissores estão sujeitos a certificação e homologação para terem sua comercialização e utilização autorizadas no Brasil. Esses equipamentos são os únicos cuja exigência de certificação é prevista na Lei Geral de Telecomunicações [9], no parágrafo $2^{\circ}$ do artigo 162. O processo de certificação, que é regido pelo Regulamento para Certificação e Homologação de Produtos para Telecomunicação, tem como objetivos gerais [34]:

- assegurar que os produtos comercializados ou utilizados no País estejam em conformidade com os regulamentos editados ou com as normas adotadas pela Anatel;

- assegurar que os fornecedores dos produtos atendam a requisitos mínimos de qualidade para seus produtos;

- assegurar que os produtos para telecomunicação comercializados no País, em particular aqueles ofertados pelo comércio diretamente ao público, possuam um padrão mínimo de qualidade e adequação aos serviços a que se destinam;

- assegurar o atendimento aos requisitos de segurança e de não agressão ao ambiente;

- facilitar a inserção do Brasil em acordos internacionais de reconhecimento mútuo. 
Cabe à Anatel emitir atos que relacionem produtos de telecomunicação que serão objeto de regulamentação, classificando-os entre as Categorias I, II e III, de acordo com a seguinte definição [34]:

- Produtos para Telecomunicação da Categoria I: equipamentos terminais destinados ao uso do público em geral para acesso a serviço de telecomunicação de interesse coletivo;

- Produtos para Telecomunicação da Categoria II: equipamentos não incluídos na definição da Categoria I, mas que fazem uso do espectro radioelétrico para transmissão de sinais, incluindo-se antenas e aqueles caracterizados, em regulamento específico, como equipamentos de radiocomunicação de radiação restrita; $e$

- Produtos para Telecomunicação da Categoria III: quaisquer produtos ou equipamentos não enquadrados nas definições das Categorias I e II, cuja regulamentação seja necessária:

(a) à garantia da interoperabilidade das redes de suporte aos serviços de telecomunicação;

(b) à confiabilidade das redes de suporte aos serviços de telecomunicação; ou

(c) à garantia da compatibilidade eletromagnética e da segurança elétrica.

Os equipamentos que fazem uso do espectro radioelétrico são classificados nas Categorias I ou II e estão listados na Tabela 6.1.

Tabela 6.1 - Produtos que fazem uso de radiofreqüência passíveis de certificação

\begin{tabular}{|c|c|}
\hline \multicolumn{2}{|c|}{ CATEGORIA I } \\
\hline FAMÍLIAS DE PRODUTOS & PRODUTOS \\
\hline ESTAÇÕES TERMINAIS DE ACESSO & $\begin{array}{l}\text { Estação terminal de acesso } \\
\text { (Equipamento destinado a proporcionar acesso aos } \\
\text { serviços: SMP, SMC ou STFC sem fio). }\end{array}$ \\
\hline TELEFONES (SERVIÇO FIXO) & $\begin{array}{l}\text { Telefone de assinante (sem cordão) } \\
\text { Sistema de ramal sem fio de CPCT }\end{array}$ \\
\hline TELEFONES (SERVIÇOS MÓVEIS) & \begin{tabular}{|l|} 
Telefone móvel celular \\
Telefone móvel por satélite \\
\end{tabular} \\
\hline TRANSCEPTORES & $\begin{array}{l}\text { Transceptor analógico troncalizado - móvel } \\
\text { Transceptor analógico troncalizado - portátil } \\
\text { Transceptor digital troncalizado - móvel } \\
\text { Transceptor digital troncalizado - portátil } \\
\text { Transceptor fixo assinante rural }\end{array}$ \\
\hline
\end{tabular}




\begin{tabular}{|c|c|}
\hline \multicolumn{2}{|c|}{ CATEGORIA II } \\
\hline FAMÍLIAS DE PRODUTOS & PRODUTOS \\
\hline AMPLIFICADORES DE POTÊNCIA RF & Amplificador de potência (exceto para estação terrena) \\
\hline ANTENAS & $\begin{array}{l}\text { Antena direcional } \\
\text { Antena omnidirecional } \\
\text { Antena para estação terrena }\end{array}$ \\
\hline $\begin{array}{l}\text { EQUIPAMENTOS (NÃO } \\
\text { RADIODIFUSÃO) }\end{array}$ & $\begin{array}{l}\text { Equipamento de ondas portadoras } \\
\text { Radar } \\
\text { Repetidor (não TV) } \\
\text { Transceptor analógico troncalizado - base } \\
\text { Transceptor com espalhamento espectral } \\
\text { Transceptor digital } \\
\text { Transceptor digital troncalizado - base } \\
\text { Transceptor fixo AM } \\
\text { Transceptor fixo base rural } \\
\text { Transceptor fixo FM } \\
\text { Transceptor móvel AM } \\
\text { Transceptor móvel FM } \\
\text { Transceptor para Sistema Automático de Identificação } \\
\text { de Navios } \\
\text { Transceptor portátil AM } \\
\text { Transceptor portátil FM } \\
\text { Transmissor de radiobaliza } \\
\text { Transmissor de radiochamada } \\
\text { Transmissor de radiofarol } \\
\text { Transmissor de supervisão e controle } \\
\text { Transmissor de telecomando } \\
\text { Transmissor de telemedição } \\
\text { Transmissor digital } \\
\text { Transmissor fixo AM } \\
\text { Transmissor fixo FM } \\
\text { Transmissor móvel AM } \\
\text { Transmissor móvel FM } \\
\text { Transmissor para o serviço avançado de mensagens }\end{array}$ \\
\hline $\begin{array}{l}\text { EQUIPAMENTOS DE RADIAÇÃO } \\
\text { RESTRITA }\end{array}$ & $\begin{array}{l}\text { Todos os produtos contemplados pela Resolução } \mathrm{n}^{\circ} \\
365 \text { exceto: } \\
\text { - Telefone de assinante (sem cordão), } \\
\text { - Telefone para ramal sem fio de CPCT, } \\
\text { - Transceptor com espalhamento espectral e, } \\
\text { - Transmissor de telecomando. }\end{array}$ \\
\hline
\end{tabular}




\begin{tabular}{|c|c|}
\hline \multicolumn{2}{|c|}{ CATEGORIA II } \\
\hline FAMÍLIAS DE PRODUTOS & PRODUTOS \\
\hline $\begin{array}{l}\text { EQUIPAMENTOS DE RADIODIFUSÃO - } \\
\text { TV }\end{array}$ & $\begin{array}{l}\text { Conversor de canal de TV } \\
\text { Modulador de áudio e vídeo } \\
\text { Repetidor de TV } \\
\text { Retransmissor de TV } \\
\text { Transceptor MMDS - retorno } \\
\text { Transmissor de televisão }\end{array}$ \\
\hline $\begin{array}{l}\text { EQUIPAMENTOS DE RADIODIFUSÃO } \\
\text { SONORA }\end{array}$ & \begin{tabular}{|l} 
Excitador de RF \\
Gerador de canal secundário (emissora FM) \\
Gerador de estereofonia (emissora FM) \\
Transmissor de radiodifusão comunitária \\
Transmissor de radiodifusão sonora em FM \\
Transmissor de radiodifusão sonora em AM \\
Transmissor de autocine
\end{tabular} \\
\hline $\begin{array}{l}\text { EQUIPAMENTOS PARA ESTAÇÃO } \\
\text { TERRENA }\end{array}$ & $\begin{array}{l}\text { Amplificador de potência } \\
\text { Conversor de subida } \\
\text { Transceptor (não SMM) } \\
\end{array}$ \\
\hline $\begin{array}{l}\text { EQUIPAMENTOS PARA SERVIÇO } \\
\text { AUXILIAR DE RADIODIFUSÃO }\end{array}$ & $\begin{array}{l}\text { Transceptor para o Serviço Auxiliar de Radiodifusão } \\
\text { Sonora } \\
\text { Transmissor para o Serviço Auxiliar de Radiodifusão } \\
\text { Sonora } \\
\text { Transmissor para o Serviço Auxiliar de Radiodifusão } \\
\text { TV }\end{array}$ \\
\hline $\begin{array}{l}\text { TRANSCEPTORES PARA ESTAÇÃO } \\
\text { RÁDIO BASE }\end{array}$ & $\begin{array}{l}\text { Transceptor para estação rádio base } \\
\text { (Equipamento destinado a prover acesso aos serviços: } \\
\text { SMP, SMC ou STFC sem fio). }\end{array}$ \\
\hline
\end{tabular}

\subsection{REGULAMENTAÇÃO TÉCNICA}

Além de emitir atos que relacionem produtos para telecomunicação que serão objeto de regulamentação, cabe também à Anatel editar regulamentos e normas a serem observados nos processos de certificação e de homologação. O Regulamento para Certificação e Homologação prevê que os regulamentos versarão sobre os requisitos aos quais os produtos devem evidenciar sua conformidade, podendo conter os procedimentos necessários para realização dos ensaios; e as normas devem tratar dos procedimentos e requisitos necessários para a condução do processo de avaliação da conformidade.

Embora o instrumento normativo que determina requisitos técnicos e procedimentos de ensaios seja o "regulamento", a Gerência de Certificação, órgão da Anatel responsável por 
essa área, tem adotado o dispositivo "norma" para esse fim. O único documento que se enquadra na definição de norma prevista no Regulamento para Certificação e Homologação é a Norma de Certificação de Produtos para Telecomunicação, aprovada pela Resolução n. ${ }^{\circ}$ 323, de 13 de novembro de 2002, que estabelece as condições mínimas necessárias à certificação e uniformiza os procedimentos entre os Organismos de Certificação Designados (OCD). Os únicos regulamentos emitidos pela Anatel no âmbito de certificação e homologação, além do próprio Regulamento para Certificação e Homologação de Produtos para Telecomunicação (Res. 242/2000), foram:

- Regulamento para a Certificação de Equipamentos de Telecomunicação quanto aos

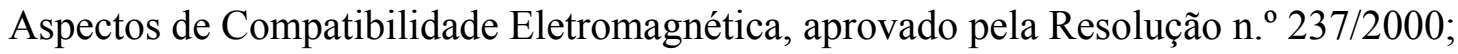

- Regulamento para a Certificação de Equipamentos de Telecomunicação quanto aos Aspectos de Segurança Elétrica, aprovado pela Resolução n. ${ }^{\circ}$ 238/2000;

- Regulamento para Certificação do Cartão Indutivo, aprovado pela Resolução n. ${ }^{\circ}$ $327 / 2002$;

- Regulamento para Certificação e Homologação de Centrais Privadas de Comutação

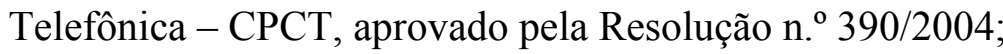

- Regulamento da Interface Usuário-Rede e de Terminais do Serviço Telefônico Fixo Comutado, aprovado pela Resolução n. ${ }^{\circ}$ 392/2005.

A Tabela 6.2 apresenta todas as Resoluções da Anatel que aprovam documentos normativos no âmbito da certificação e homologação de produtos, a data de sua publicação no Diário Oficial da União e um resumo de seu escopo, com atualização em março de 2006.

Tabela 6.2 - Resoluções aprovadas pela Anatel no âmbito da certificação de produtos.

\begin{tabular}{|c|c|l|}
\hline Num. & Data DOU & \multicolumn{1}{|c|}{ Assunto } \\
\hline 414 & $30 / 09 / 2005$ & $\begin{array}{l}\text { Aprova Norma para Certificação e Homologação de Equipamentos para Estações Terrenas } \\
\text { do Serviço Fixo por Satélite. }\end{array}$ \\
\hline 413 & $05 / 09 / 2005$ & $\begin{array}{l}\text { Aprova Norma para Certificação e Homologação de Transmissores e Transceptores de } \\
\text { Estações Rádio Base e de Estações Repetidoras do Serviço Móvel Pessoal (SMP) e } \\
\text { Serviço Móvel Especializado (SME) }\end{array}$ \\
\hline 412 & $15 / 08 / 2005$ & Aprova Norma para Certificação e Homologação de Telefones de Uso Público \\
\hline 399 & $20 / 04 / 2005$ & Aprova Norma para Certificação e Homologação de Conectores para Cabos Coaiais \\
\hline 394 & $02 / 03 / 2005$ & $\begin{array}{l}\text { Aprova a Norma para Certificação e Homologação de Acumuladores Chumbo-Ácido } \\
\text { Estacionários Regulados por Válvula }\end{array}$ \\
\hline 392 & $28 / 02 / 2005$ & $\begin{array}{l}\text { Aprova o Regulamento da Interface Usuário-Rede e de Terminais do Serviço Telefônico } \\
\text { Fixo Comutado }\end{array}$ \\
\hline 390 & $17 / 12 / 2004$ & $\begin{array}{l}\text { Aprova o Regulamento para Certificação e Homologação de Centrais Privadas de } \\
\text { Comutação Telefônica - CPCT. }\end{array}$ \\
\hline
\end{tabular}




\begin{tabular}{|c|c|c|}
\hline Num. & Data DOU & Assunto \\
\hline 385 & 07/10/2004 & $\begin{array}{l}\text { Aprova Norma para Certificação e Homologação de Acumuladores Chumbo-Ácido } \\
\text { Estacionários Ventilados. }\end{array}$ \\
\hline 384 & 07/10/2004 & $\begin{array}{l}\text { Aprova Norma para Certificação e Homologação de Acumuladores Alcalinos de Níquel- } \\
\text { Cádmio Estacionários. }\end{array}$ \\
\hline 383 & $06 / 10 / 2004$ & Aprova Norma para Certificação e Homologação de Cabos Coaxiais Rígidos de 75 Ohms. \\
\hline 382 & 06/10/2004 & $\begin{array}{l}\text { Aprova Norma para Certificação e Homologação de Cabos Coaxiais Flexíveis de } 50 \text { Ohms } \\
\text { ou } 75 \text { Ohms. }\end{array}$ \\
\hline 381 & 06/10/2004 & $\begin{array}{l}\text { Aprova Norma para Certificação e Homologação de Cabos Coaxiais Flexíveis de } 75 \text { Ohms } \\
\text { com Malha de Fios de Alumínio. }\end{array}$ \\
\hline 380 & 06/10/2004 & $\begin{array}{l}\text { Aprova Norma para Certificação e Homologação de Cabos Coaxiais Semi-Rígidos de } 50 \\
\text { Ohms }\end{array}$ \\
\hline 379 & 05/10/2004 & $\begin{array}{l}\text { Aprova Norma para Certificação e Homologação de Acumuladores Chumbo-Ácido } \\
\text { Estacionários para Aplicações Específicas. }\end{array}$ \\
\hline 372 & $24 / 05 / 2004$ & $\begin{array}{l}\text { Aprova a Norma para Certificação e Homologação de Antenas Setoriais e } \\
\text { Omnidirecionais. }\end{array}$ \\
\hline 370 & $17 / 05 / 2004$ & $\begin{array}{l}\text { Aprova Norma para Certificação e Homologação de Transmissores e Transceptores } \\
\text { Monocanais Analógicos AM. }\end{array}$ \\
\hline 369 & $17 / 05 / 2004$ & $\begin{array}{l}\text { Aprova Norma para Certificação e Homologação de Transmissores e Transceptores } \\
\text { Digitais para o Serviço Fixo em Aplicações Ponto-a-Ponto nas Faixas de Freqüências } \\
\text { acima de } 1 \text { GHz. }\end{array}$ \\
\hline 368 & $17 / 05 / 2004$ & $\begin{array}{l}\text { Aprova Norma para Certificação e Homologação de Transmissores e Transceptores } \\
\text { Digitais para o Serviço Fixo em Aplicações Ponto-Multiponto nas Faixas de Freqüências } \\
\text { acima de } 1 \mathrm{GHz} \text {. }\end{array}$ \\
\hline 367 & $17 / 05 / 2004$ & Aprova a Norma para Certificação e Homologação de Antenas Direcionais de Abertura. \\
\hline 366 & $17 / 05 / 2004$ & Aprova a Norma para Certificação e Homologação de Antenas Lineares \\
\hline 364 & $12 / 05 / 2004$ & Aprova a Norma para Certificação e Homologação de Antenas para Estações Terrenas \\
\hline 361 & $22 / 04 / 2004$ & $\begin{array}{l}\text { Aprova Norma para Certificação e Homologação de Transmissores e Transceptores } \\
\text { Monocanais Analógicos FM e PM para Operação nas Faixas de Freqüências Abaixo de } 1 \\
\text { GHz. }\end{array}$ \\
\hline 360 & $22 / 04 / 2004$ & $\begin{array}{l}\text { Aprova Norma para Certificação e Homologação de Transmissores e Transceptores } \\
\text { Digitais para o Serviço Fixo em Aplicações Ponto-a-Ponto nas Faixas de Freqüências } \\
\text { abaixo de } 1 \mathrm{GHz} \text {. }\end{array}$ \\
\hline 359 & $22 / 04 / 2004$ & $\begin{array}{l}\text { Aprova Norma para Certificação e Homologação de Transmissores e Transceptores } \\
\text { Digitais para o Serviço Fixo em Aplicações Ponto-Multiponto nas Faixas de Freqüências } \\
\text { abaixo de } 1 \mathrm{GHz} \text {. }\end{array}$ \\
\hline 348 & $04 / 09 / 2003$ & $\begin{array}{l}\text { Aprova a Norma para Certificação e Homologação de Cabos Pára-raios com Fibras } \\
\text { Ópticas para Linhas Aéreas de Transmissão (OPGW). }\end{array}$ \\
\hline 327 & $23 / 12 / 2002$ & Aprova o Regulamento para Certificação do Cartão Indutivo \\
\hline 323 & $13 / 11 / 2002$ & Aprova a Norma para Certificação de Produtos para Telecomunicação \\
\hline 306 & 06/08/2002 & $\begin{array}{l}\text { Aprova a Norma para Certificação e Homologação de Bloqueador de Sinais de } \\
\text { Radiocomunicações. }\end{array}$ \\
\hline 300 & $24 / 06 / 2002$ & Aprova a Norma para Certificação e Homologação de Cabos Telefônicos Metálicos. \\
\hline 299 & $24 / 06 / 2002$ & Aprova a Norma para Certificação e Homologação de Cabos de Fibras Ópticas \\
\hline 242 & $05 / 12 / 2000$ & $\begin{array}{l}\text { Aprova o Regulamento para Certificação e Homologação de Produtos para } \\
\text { Telecomunicação }\end{array}$ \\
\hline 238 & $13 / 11 / 2000$ & $\begin{array}{l}\text { Aprova o Regulamento para a Certificação de Equipamentos de Telecomunicação Quanto } \\
\text { aos Aspectos de Segurança Elétrica. }\end{array}$ \\
\hline 237 & $14 / 11 / 2000$ & $\begin{array}{l}\text { Aprova o Regulamento para a Certificação de Equipamentos de Telecomunicação Quanto } \\
\text { aos Aspectos de Compatibilidade Eletromagnética. }\end{array}$ \\
\hline 146 & $22 / 07 / 1999$ & $\begin{array}{l}\text { Aprova o Regulamento para Certificação de Sistemas de Acesso Fixo sem Fio para a } \\
\text { Prestação do Serviço Telefônico Fixo Comutado Destinado ao Uso do Público em Geral - } \\
\text { STFC. }\end{array}$ \\
\hline 47 & $11 / 08 / 1998$ & Aprova as Diretrizes para o Modelo de Certificação de Equipamentos de Comunicação \\
\hline
\end{tabular}




\subsubsection{Situações de Inexistência de Regulamentos}

$\mathrm{Na}$ ausência de regulamentos ou de normas para certificação expedidos pela Anatel, e caso a Agência delibere favoravelmente quanto a oportunidade e a viabilidade da avaliação da conformidade e da homologação, a Agência poderá:

- exigir a realização de ensaios em laboratórios e testes de campo;

- estabelecer, mediante referência, os requisitos técnicos ou normas técnicas a serem aplicados ao processo de avaliação da conformidade. Essas normas deverão ser:

a) normas técnicas nacionais ou internacionais;

b) regulamentos aplicáveis ao produto em outros países ou regiões;

c) regulamentos editados pela Anatel para produtos similares; ou

d) especificações do fabricante.

- iniciar estudos para a edição de regulamento versando sobre o produto e fixar as condições a serem observadas na avaliação da conformidade e na homologação do produto.

Além de estabelecer os requisitos técnicos, em caráter provisório, e iniciar estudos para a edição de novo regulamento, cabe à Anatel, nos termos da Lei Geral das Telecomunicação, substituir gradativamente os regulamentos, normas e demais regras em vigor por regulamentação editada pela Agência. No âmbito da certificação, as normas e regulamentos da Anatel vêm substituindo as orientações normativas da Telebrás e do Ministério das Comunicações. A Agência tem demonstrado a preocupação de editar normas e regulamentos alinhados com as normativas internacionais, de forma a facilitar a integração tecnológica do Brasil com outros países.

\subsection{ACORDOS DE RECONHECIMENTO MÚTUO}

O Regulamento para Certificação e Homologação de Produtos para Telecomunicação prevê que a Anatel poderá firmar Acordos de Reconhecimento Mútuo (ARM), em matéria de avaliação da conformidade de produto de telecomunicação, tendo por objetivo o reconhecimento de organismos de certificação e de laboratórios de ensaio, como partes integrantes do sistema de avaliação da conformidade por ela adotado. 
O Regulamento prevê ainda que os procedimentos de avaliação da conformidade e os relatórios de ensaios expedidos, respectivamente, pelos organismos de certificação e pelos laboratórios de ensaios deverão ser conduzidos e elaborados de acordo com os regulamentos editados pela Anatel ou normas por ela adotadas, bem como deverão ser expressos preferencialmente em língua portuguesa, podendo, facultativamente, ser expressos em língua inglesa ou espanhola.

Outra determinação do Regulamento é que o escopo dos ARM firmados pela Anatel tenha abrangência limitada aos procedimentos de avaliação da conformidade e que, no caso dos ARM envolverem o reconhecimento de laboratórios de ensaios, os mesmos deverão ser reconhecidos pelos OCD. Os ARM poderão contemplar o reconhecimento de OCD que atuam, também, como laboratórios de ensaios. Na implementação dos ARM, será observado, sempre que necessário, um período de transição durante o qual a administração brasileira avaliará as entidades designadas pelas administrações estrangeiras quanto aos aspectos relativos à conformidade com a regulamentação vigente, incluindo os procedimentos por elas adotados.

Até o momento não foi firmado nenhum ARM. Entretanto, as diretrizes básicas e a concepção dos ARM já estão aprovadas no âmbito da CITEL. As primeiras adesões, entre os países americanos membros da CITEL, foram iniciadas e espera-se, para breve, a adesão brasileira. No âmbito da Mercosul também está sendo estruturado e negociado, entre os países membros, um ARM regional. [35]

\subsection{O PROCESSO DE CERTIFICAÇÃO E HOMOLOGAÇÃO}

Com o objetivo de tornar a certificação e homologação dos produtos para telecomunicação mais rápida e desobrigar a Agência a ter uma infra-estrutura muito dispendiosa, a Anatel determinou que a condução dos processos de certificação deve ser efetuada por Organismos de Certificação Designados (OCD). Esses organismos são responsáveis por acompanhar os testes, realizados por laboratórios contratados pelo próprio OCD e pelo solicitante (fabricante ou fornecedor), e emitir o Certificado de Conformidade. Assim, a participação da Agência na maioria dos casos restringe-se apenas à etapa de homologação, em que o certificado de conformidade é validado pela Anatel, autorizando a comercialização e a utilização do produto no País. 


\subsubsection{Organismos de Certificação Designados}

Para o início do procedimento administrativo de designação de Organismo de Certificação, é necessário que o próprio organismo firme termo de responsabilidade e o compromisso de desempenhar as atividades propostas dentro dos padrões de idoneidade, rigor técnico e procedimental previstos em regulamentação. Um dos seguintes requisitos deve ser atendido para que um organismo de certificação seja designado pela Anatel [34]:

- organismos credenciados pelo Inmetro para certificação de produtos de telecomunicação;

- entidades estabelecidas no Brasil, sem fins lucrativos, com capacidade técnica e administrativa necessárias à boa condução de processo de avaliação da conformidade de produtos de telecomunicação; ou

- organismos de certificação estrangeiros reconhecidos por meio de Acordo de Reconhecimento Mútuo.

Além desses requisitos, as instituições devem demonstrar ter as seguintes características:

- capacidade técnica para o exercício das funções que lhes forem atribuídas;

- $\quad$ idoneidade que lhes permita exercer com independência suas funções; $e$

- regularidade jurídica, que demonstre ser pessoa jurídica regularmente constituída e representada.

\subsubsection{Avaliação da Conformidade}

A etapa inicial do processo de Certificação e Homologação é a avaliação da conformidade. Para comprovação da conformidade perante a Anatel, o interessado deverá apresentar um dos seguintes documentos [34]:

- Declaração de Conformidade: é o documento de avaliação da conformidade aplicável aos produtos de fabricação artesanal para uso próprio, não gerando direito de autorização para comercialização do produto no País.

- Declaração de Conformidade com relatórios de ensaio: é o documento de avaliação da conformidade aplicável na hipótese excepcional em que os organismos de certificação designados fixarem prazos superiores a três meses para iniciar e concluir o processo de expedição de certificado de conformidade, excluído o período necessário à realização dos ensaios, sendo a Anatel responsável por promover a condução do processo de avaliação da conformidade. Aplica-se essa mesma regra quando não houver organismos de certificação designados e 
habilitados a conduzir a avaliação da conformidade ou na hipótese de Produtos de Telecomunicação da Categoria I destinados ao uso de portadores de deficiência com produção em pequena escala.

- Certificado de Conformidade baseado em ensaio de tipo: é o documento atestatório da avaliação da conformidade aplicável aos Produtos de Telecomunicação de Categoria III.

- Certificado de Conformidade com ensaios de tipo e avaliações periódicas do produto: é o documento atestatório da avaliação da conformidade aplicável aos Produtos de Telecomunicação de Categoria II.

- Certificado de Conformidade com avaliação do sistema de qualidade: é o documento atestatório da avaliação da conformidade aplicável aos Produtos de Telecomunicação de Categoria I.

Os Certificados de Conformidade são emitidos por OCDs a partir de relatórios de ensaio elaborados pelo laboratório em que os testes foram realizados. Deve-se dar preferência para laboratórios credenciados pelo Inmetro e caracterizados como de terceira parte, isto é, que agem com total independência de fabricantes, fornecedores, prestadoras de serviços de telecomunicação ou potenciais compradores do produto.

A etapa de avaliação da conformidade é, em suma, caracterizada pela confrontação dos resultados obtidos nos ensaios e a regulamentação aplicável. O certificado de conformidade é uma declaração de que todos os requisitos técnicos aplicáveis exigidos pela regulamentação vigente são atendidos pelo produto.

\subsubsection{Ensaios Realizados em Laboratório do Próprio Fabricante}

Nos casos de produtos de grande porte e complexidade de instalação, ou de baixa escala de produção, a Anatel pode autorizar o OCD a aceitar os ensaios realizados em laboratório de primeira parte, isto é, do próprio fabricante, desde que este utilize instrumental de testes e medições, bem como artefatos adequados e calibrados, comprovados por certificados de calibração emitidos pelo Inmetro, por laboratório credenciado ou por instituição técnica devidamente capacitada; possua procedimentos controlados e sistematizados para a realização dos ensaios laboratoriais; e disponha de pessoal apto a realizar os ensaios. Exige-se também nesses casos que um representante do OCD acompanhe a realização dos testes. Atualmente, há seis laboratórios de primeira parte avaliados e autorizados [35]: 
- OPTEL

- Siemens Ltda.

- Brasfio Ind. Com. S.A.

- Ficap S/A

- Pirelli Telecomunicações Cabos e Sistemas do Brasil S.A.

- Laboratório de Queima Vertical Dacarto Benvic S.A.

\subsubsection{Homologação}

Uma vez avaliada a conformidade de um produto e emitido o Certificado de Conformidade, deve-se proceder à homologação. São partes legítimas para pleitear, junto à Anatel, a homologação de produtos, na condição de parte interessada e responsável: o fabricante do produto; o fornecedor do produto no País; e pessoa física ou jurídica que solicita a homologação de produto de telecomunicação para uso próprio.

O requerimento de homologação deve ser instruído acompanhado de:

- Certificado ou Declaração de Conformidade, demonstrando a conformidade do produto;

- Comprovante de recolhimento dos emolumentos devidos;

- Manual do usuário do produto redigido em língua portuguesa. Nas hipóteses em que o produto não seja destinado à venda direta ao consumidor, o manual poderá ser redigido em língua inglesa ou espanhola.

- Informações cadastrais do interessado;

- Comprovação de que a parte interessada está regularmente estabelecida segundo as leis brasileiras, ou possui representante comercial estabelecido no Brasil, de forma a se responsabilizar pela qualidade, fornecimento e assistência técnica relativos ao produto no território nacional;

- Cópia da Carta de Licenciamento do prefixo EAN.UCC de código de barras, fornecida pela EAN Brasil, o que garante que o código de barras de identificação da homologação dos produtos para telecomunicação siga o padrão adotado pela Anatel;

- Fotografias internas; 
- Fotografias externas, mostrando nitidamente a etiqueta de identificação do modelo e do fabricante, e o local em que será afixado o selo de homologação da Anatel.

Atualmente, o requerimento de homologação é instruído junto à Anatel através do Sistema de Gestão de Certificação e Homologação (SGCH), acessível no sítio da Agência na Internet, e não há envio de documentos em papel, apenas em formato eletrônico (.pdf). $\mathrm{O}$ requerimento só entra na fase de análise depois da comprovação de recolhimento dos emolumentos. O valor da taxa, definido no Anexo II da Resolução 242/2000, é apresentado na Tabela 6.3.

Depois de ser analisado, o processo é aprovado pelo Gerente de Certificação e é emitido o Certificado de Homologação. Este certificado autoriza a comercialização do produto no País.

Tabela 6.3 - Emolumentos para homologação definidos pela Resolução 242/2000

\begin{tabular}{|l|c|}
\hline \multicolumn{1}{|c|}{ Tipo de Processo } & Valor \\
\hline Homologação de Certificado de Conformidade & $\mathrm{R} \$ 500,00$ \\
\hline Homologação de Declaração de Conformidade & $\mathrm{R} \$ 200,00$ \\
\hline Renovação de Homologação & $\mathrm{R} \$ 200,00$ \\
\hline
\end{tabular}

\subsubsection{Homologação por Famílias de Produtos}

É possível que se efetue a certificação e homologação por famílias para determinados produtos, desde que sejam atendidas certas condições. Entre os produtos que fazem uso do espectro de radiofreqüência, os únicos que se enquadram nessa possibilidade são os transmissores de radiodifusão e as antenas. Os transmissores modulares, fabricados com tecnologia de estado sólido e que utilizem os mesmos projetos das placas de circuitos e os mesmos componentes, poderão ser considerados como modelos de uma mesma família de produtos, considerando que os modelos de uma mesma família diferenciam-se apenas pela quantidade de módulos amplificadores do estágio final. Os ensaios devem ser, preferencialmente, realizados no equipamento de maior potência e devem ser realizados ensaios de atenuação de harmônicos e espúrios. Para os transmissores valvulados, qualquer alteração da válvula do estágio final é considerada como a constituição de um novo modelo [36]. 
Com relação às antenas, esses produtos são submetidos aos ensaios referentes às características elétricas (ganho, diagrama de radiação, coeficiente de onda estacionária e polarização) e o fabricante deve fornecer uma declaração de conformidade referente às características mecânicas e ambientais (resistência ao vento, proteção contra chuva, comportamento em função da temperatura). No caso de uma família de antenas, definida como "conjunto de modelos de antenas, de um mesmo fabricante, com a mesma largura de feixe no plano horizontal, a mesma polarização, a mesma faixa de freqüências, e com elementos constitutivos de mesma natureza" [37], apenas o modelo de menor ganho é submetido aos ensaios para avaliação da conformidade. Para os demais modelos deve ser fornecida, pelo fabricante, uma declaração de conformidade relativa aos requisitos elétricos, mecânicos e ambientais, anexando inclusive os diagramas de radiação de cada modelo pertencente à família. A certificação e homologação do modelo de menor ganho abrangerá a certificação e a homologação dos demais modelos constitutivos de uma mesma família.

Antenas que sejam mecanicamente incorporadas a transceptores, e que não sejam comercializadas como um produto isolado, não são sujeitas à certificação e homologação junto à Anatel. Entretanto, os diagramas de radiação e as especificações das características elétricas, mecânicas e ambientais dessas antenas deverão ser fornecidos no processo de certificação e homologação dos transceptores. A comprovação da conformidade das características elétricas, mecânicas e ambientais dessas antenas deverá ser feita por declaração fornecida pelo fabricante. As antenas para uso no interior de edificações estão dispensadas da homologação junto à Anatel [37, 38, 39].

\subsection{COMPATIBILIDADE ELETROMAGNÉTICA, SEGURANÇA ELÉTRICA E EXPOSIÇÃO A RADIAÇÃO NÃO-IONIZANTE}

Além dos requisitos específicos para cada produto, existem três documentos normativos que contemplam um grande número de produtos para telecomunicação: a Resolução n. ${ }^{\circ} 237$ e a Resolução n. ${ }^{\circ}$ 238, ambas de 9 de novembro de 2000, que aprovam os regulamentos para certificação de equipamentos de telecomunicação quanto aos aspectos de Compatibilidade Eletromagnética e Segurança Elétrica, respectivamente; e a Resolução 303, de 2 de julho de 2002, que aprova o Regulamento sobre Limitação da Exposição a Campos Elétricos, Magnéticos e Eletromagnéticos na Faixa de Radiofreqüências entre $9 \mathrm{kHz}$ e 300 
GHz. Importante ressaltar que tais dispositivos regulamentares estão alinhados com as recomendações internacionais para o assunto, seguindo as diretrizes mais reconhecidas pela comunidade científica e pelo mercado.

\subsubsection{Compatibilidade Eletromagnética}

O Regulamento para Certificação de Equipamentos de Telecomunicação quanto aos Aspectos de Compatibilidade Eletromagnética tem em sua abrangência, entre outros, os produtos que fazem uso do espectro de radiofreqüência destinados a instalação no ambiente de usuário e que possuam alimentação de energia local ou que estejam conectados à rede telefônica por meio de fios ou cabos metálicos. Estabelece que estes produtos devem atender a requisitos de resistibilidade a perturbações eletromagnéticas, isto é, limites que visam a garantir o funcionamento normal dos equipamentos, quando estes são submetidos a perturbações eletromagnéticas conduzidas, cuja intensidade seja compatível com seus ambientes de operação [40]. Os ensaios previstos verificam a capacidade do produto de suportar a aplicação de perturbações eletromagnéticas nos seus terminais de telecomunicação (terminais por meio dos quais trafega a informação) e de energia elétrica (terminais por meio dos quais é fornecida a energia destinada ao seu funcionamento); o regulamento determina que após a aplicação das perturbações, o equipamento deve apresentar funcionamento normal.

\subsubsection{Segurança Elétrica}

Entre os produtos aos quais o Regulamento para Certificação de Equipamentos de Telecomunicação quanto aos Aspectos de Segurança Elétrica se aplica estão os produtos que utilizam radiofreqüência destinados a instalação em ambiente do usuário. Para esses produtos, são exigidos testes para os seguintes requisitos:

\section{- Proteção Contra Choque Acústico}

Quando em operação normal ou quando submetido a perturbações eletromagnéticas transitórias nos seus terminais, o equipamento que possuir saída acústica não deve produzir pressão acústica transitória superior a $135 \mathrm{~dB}$ de pico, relativos a $20 \mu \mathrm{Pa}$, ou seja, a máxima pressão acústica aceitável é de 112,5 $\mathrm{Pa}$. 


\section{- Proteção Contra Choque Elétrico}

Estando o equipamento energizado em condições normais, todas as suas partes acessíveis devem apresentar corrente de fuga inferior a 0,25 mA, em valores RMS.

- Proteção Contra Aquecimento Excessivo

A elevação de temperatura em relação ao ambiente, de qualquer parte externa do equipamento acessível, não deve exceder os limites da Tabela 6.4 [41].

Tabela 6.4 - Limites para elevação de temperatura

\begin{tabular}{|l|c|c|}
\hline & Superfície Metálica & Superfície Não-Metálica \\
\hline Partes tocadas freqüentemente & $30^{\circ} \mathrm{C}$ & $40^{\circ} \mathrm{C}$ \\
\hline Partes tocadas eventualmente & $45^{\circ} \mathrm{C}$ & $55^{\circ} \mathrm{C}$ \\
\hline
\end{tabular}

\subsubsection{Exposição a Radiação não-Ionizante}

No que tange à exposição humana a radiação eletromagnética, o Regulamento aprovado pela Resolução n. ${ }^{\text {o } 303 / 2002 ~ d e t e r m i n a ~ q u e ~ o s ~ t e r m i n a i s ~ d o ~ S e r v i c ̧ o ~ M o ́ v e l ~}$ Especializado, do Serviço Móvel Celular e do Serviço Móvel Pessoal devem atender aos limites de exposição como pré-requisito para certificação e homologação do produto [23].

Art. 22. Para certificação de equipamento terminal do Serviço Móvel Especializado, do Serviço Móvel Celular e do Serviço Móvel Pessoal, deverão ser apresentados pelo fornecedor, além dos documentos obrigatórios já exigidos, Relatório de Testes e Laudo Conclusivo referentes ao atendimento aos limites da SAR.

$\S 1^{o}$. Serão aceitos Relatório de Testes e o Laudo Conclusivo de laboratório de primeira, segunda ou terceira partes capacitado para a realização dos testes.

$\S 2^{\circ}$. Até que venha a ser estabelecido um padrão em nível internacional, será admitido o uso de procedimentos de testes elaborados por entidades especializadas em estudos sobre campos eletromagnéticos, tais como o Institute of Electrical and Electronics Engineers (IEEE) e o European Commitee for Electrotechnical Standardization (CENELEC).

\subsection{ESTUDO DE CASO}

De forma a esclarecer melhor o procedimento envolvido no processo de certificação e homologação de produtos para telecomunicação junto à Anatel, apresenta-se a seguir o caso de 
uma antena, certificada pela Associação NCC Certificações do Brasil. Trata-se de uma antena parabólica vazada, modelo GI 09 25, fabricada pela Ideal Indústria e Comércio de Antenas Ltda., para utilização na faixa de 2,4 GHz. Fotos da antena são apresentadas na Figura 6.1 e suas características técnicas encontram-se listadas na Tabela 6.5 [42].

Os ensaios foram realizados no Laboratório de Antenas do Instituto Nacional de Pesquisas Especiais (INPE), em 17 de dezembro de 2005, e foram medidos os seguintes parâmetros, de acordo com a Norma para Certificação e Homologação de Antenas Direcionais de Abertura, aprovada pela Resolução n. ${ }^{\text {o } 367: ~}$

- Ganho da antena [dBi]

- Largura de feixe no plano horizontal [graus]

- Largura de feixe no plano vertical [graus]

- Diagrama de radiação co-polar no plano horizontal

- Diagrama de radiação co-polar no plano vertical

- Diagrama de radiação polarização cruzada no plano horizontal

- Diagrama de radiação polarização cruzada no plano vertical

A Figura 6.2 apresenta os diagramas de radiação dessa antena nos planos horizontal e vertical, respectivamente.

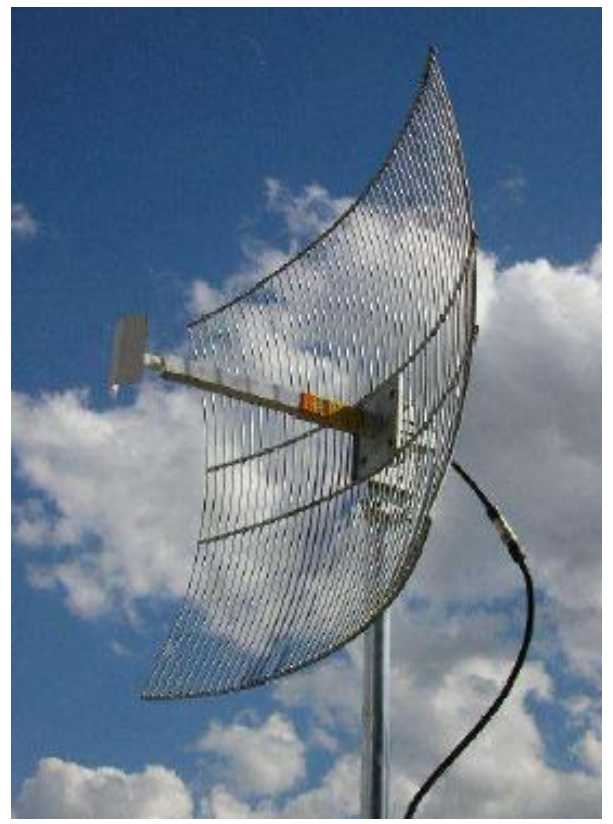

(a)

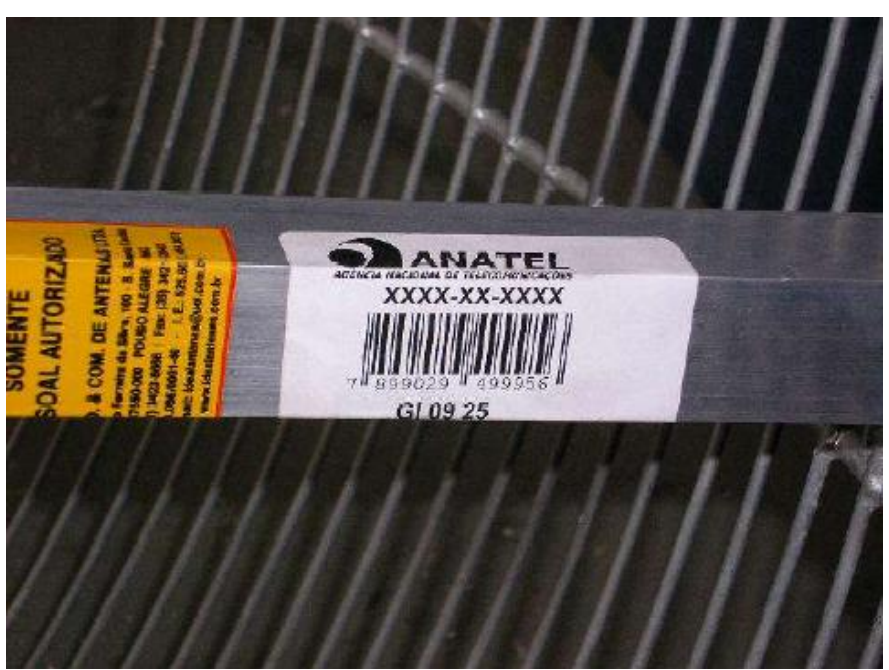

(b)

Figura 6.1 - Antena modelo GI 09 25. (a) perspectiva; (b) foto do selo Anatel de homologação. 
Tabela 6.5 Características Técnicas da Antena modelo GI 0925

\begin{tabular}{|l|c|}
\hline Faixa de Freqüência & $2,4-2,5 \mathrm{GHz}$ \\
\hline Refletor & Vazado \\
\hline Diâmetro & $90 \mathrm{~cm}$ \\
\hline Potência de entrada & 100 watts \\
\hline Impedância de entrada & 50 ohms \\
\hline Ganho & $24 \mathrm{dBi}$ \\
\hline Relação F/C & Melhor que $20 \mathrm{~dB}$ \\
\hline VSWR na banda & $1,2: 1$ \\
\hline Polarização & Linear \\
\hline Peso & $5 \mathrm{~kg}$ \\
\hline Conectores & N Fêmea / N macho \\
\hline
\end{tabular}

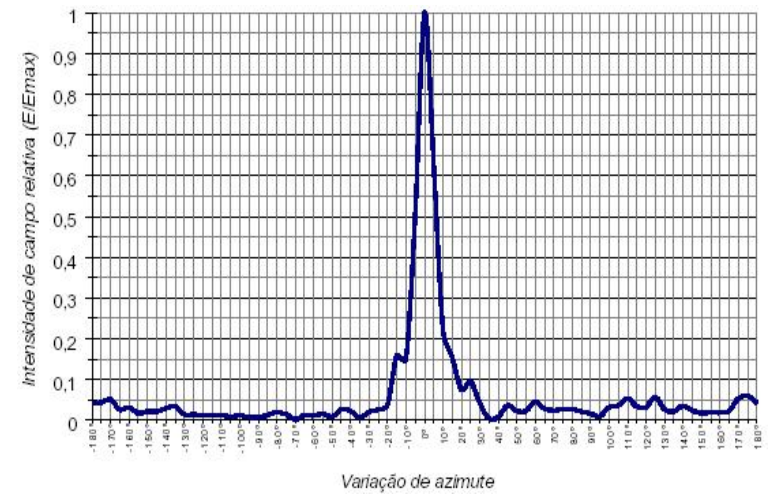

(a)

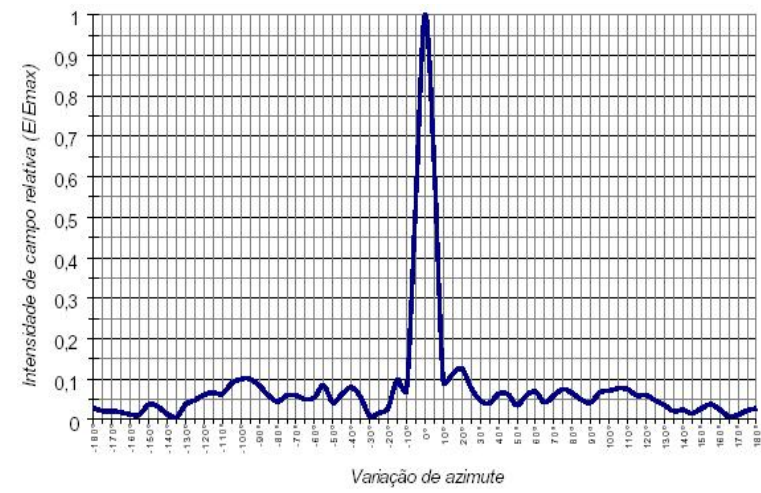

(b)

Figura 6.2 - Diagrama de radiação co-polar da antena modelo GI 0925.

(a) plano horizontal; (b) plano vertical

A partir dos ensaios realizados, o Laboratório de Antenas do INPE elaborou o Relatório ID05-R01, que foi apresentado ao OCD Associação NCC Certificações do Brasil. Com base no relatório de ensaio e na declaração do fabricante de que a antena atende aos requisitos mecânicos e ambientais (resistência ao vento, proteção contra chuva e faixa de temperatura), o OCD emitiu o Certificado de Conformidade NCC 2345/05, em 21 de março de 2005. Todos esses documentos, juntamente com aqueles listados no item 6.3.4, foram apresentados à Anatel, através do sistema interativo SGCH. Após análise do processo, a Gerência de Certificação aprovou o requerimento de homologação, sendo emitido em 4 de abril de 2005 o Certificado de Homologação n. ${ }^{\circ}$ 0303-05-2593, que autoriza a comercialização e o uso do produto no Brasil.

As Figuras 6.3 e 6.4 apresentam, respectivamente, o Certificado de Conformidade e o Certificado de Homologação da antena modelo GI 0925. 


\section{Associação NCC Certificações do Brasil}

\section{CERTIFICADO DE CONFORMIDADE TÉCNICA PARA PRODUTOS DE TELECOMUNICAÇÕES

\author{
INTRANSFERIVEL
}

Organisme Certificador:Associação NCC Certificaçōes do Brasil

Número do Certificado:NCC 2345/05 Data da Certificaçăo:21/03/2005

Emissāo:21/03/2005

Validade: $21 / 03 / 2007$

Tipo de Certificado: Certificado de Conformidade baseado em ensaio de tpo e em avaliaçōes periódicas do produto

Solicitante

IDEAL Indústria e Comércio de Antenas Ltda

Rua Fernando Ferreira Silva, 100-Bairro Sta Cecilia - Pouso Alegre-MG - CEP 37550-000

CNPJ: $25.160 .086 / 0001-40$

Fabricante / Unidade Fabril

Telecomunicaçס̄es IDEAL Indústria e Comércio de Antenas Ltda

Rua Feliciano Teles, 244 - Bairro Inatel-Santa Rita do Sapucai-MG - CEP 37540-000

CNPJ: 05.725.216/0001-38

Produto: Antena Direcional.

Categoria: II

Modelo: GI 0925

Tipo de Produto: Antena direcional

Tipo de Serviço: Serviço Fixo

Os Produtos classificados na Categoria II, objeto do certificado de conformidade, estão aujeito à comprovaç̧̃o periódica de que mantém as características originalmente certificadas.

Norma(s) Técnica(s): Resolução no 367 (2004).

Caracteristicas Técnicas Basicas: Faixa de rrequência de operaçå: $2400 \mathrm{MHz}$ a 2500 $\mathrm{MHz}$; Ganho Minimo: $24,28 \mathrm{dBi}$; Ângulo de $1 / 2$ potência: $8,66^{\circ}$; Relação Frente-Costas: 45 dB; Polarização: Horizontal ou Vertical; Tipo de antena: Parabólica vazada; Antena Direcional de Abertura, atendendo a envoltríria correspondente à CS1.*/

Certifico, nos termos do Ato de Designação $n^{\circ} 16.955$ e do Termo de Responsabilidade 002 /RFGCT/RFCE/SRF de $08 / 06 / 2001$, que o produto acima especificado atende as normas e resoluçós da ANATEL sendo que o mesmo deverá obrigatoriamente, ser homologado por estâ. Agência e portar Etiqueta Anatel para fins de comercialização e uso.

Autenticaçāo
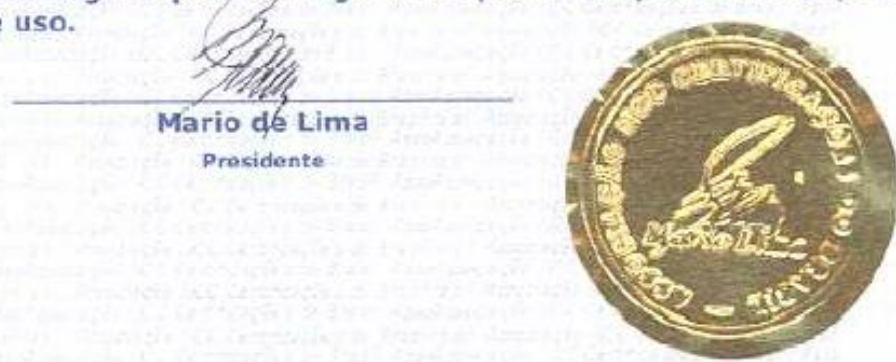

Figura 6.3 - Certificado de Conformidade da antena modelo GI 0925. 
REPÚBLICA FEDERATIVA DO BRASIL

AGÊNCIA NACIONAL DE TELECOMUNICAÇỐES

\title{
ANATEL
}

\author{
Certificado de Homologação \\ (Intransferivel) \\ No 0303-05-2593
}

Validade: Indeterminada

Emissã̉o: 04/04/2005

Fabricante:

Telecomunicações IDEAL Ind e Com. de Antenas Ltda.

Rua Feliciano Teles 244 Inatel

37540-000 - Santa Rita do Sapucai - MG

Este documento homologa, nos termos do Regulamento para Certificaçâo e Honologaçấo de Produtos para Telecomunicaçốes, aprovado pela Resoluçấo Anatel $n^{\circ} 242$, de 30 de novembro de 2000 , o Certificado de Conformidade $n^{\circ}$ NCC 2345105 de 21 de março de 2005, emitido pelo 0CD - Associação HCC Certificações do Brasil. Esta homologaçắo é expedida em nome do fabricante aqui identificado e é válida somente para o produto a seguir discriminado, cuja utilização deve observar as condiçốes estabelecidas na regulamentaçẫo do serviço a que se destina.

Tipo:

Antena Direcional - Categoria II

Modelo(s):

GI 0925

Serviço/Aplicaçẫo:

Serviço Fixo

Características técnicas básicas:

\begin{tabular}{|c|c|c|c|c|c|}
\hline $\begin{array}{c}\text { Faixa de Frequências } \\
\text { (MHz) }\end{array}$ & $\begin{array}{c}\text { Ganho Mínimo } \\
\text { (dBi) }\end{array}$ & $\begin{array}{c}\text { angulo de 1/2 Potência Relação Frente/Costa } \\
\text { (graus) }\end{array}$ & Polarização & Tipo da Antena \\
\hline 2400,0 a 2500,0 & 24,28 & 8,66 & 45,0 & Hou V & Parabólica \\
\hline
\end{tabular}

Observaçôes:

Constitui obrigação do fabricante do produto no Brasil providenciar a identificaçấo do produto homologado, nos termos do art. 39 do Regulamento anexo à Resoluçẫo Anatel $n^{\circ} 242$, em todas as unidades comercializadas, antes de sua efetiva distribuiçấo ao mercado, assim como observar e manter as características técnicas que fundamentaram a certificaçăo original.

As informações constantes deste certificado de homologação podem ser confirmadas no SGCH - Sistema de Gestão de Certificação e Homologação, disponível no portal da Anatel. (www.anatel.gov.br).

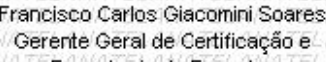

Francisco Carlos Giacomini Soares

Gerente Geral de Certificação e

Engenharia do Espectro

Figura 6.4 - Certificado de Homologação da antena modelo GI 0925. 


\section{CONCLUSÃO}

Quando se trata de regulação do espectro de radiofreqüências, destaca-se a característica intrinsecamente internacionalizada do tratamento do assunto, tanto por questões críticas nas regiões de fronteira, quanto para garantia de compatibilidade entre sistemas, o que justifica o fato de que o espectro tem sido primordialmente regulado em nível internacional.

No caso específico brasileiro, no início do século XX surgiram os primeiros esforços governamentais no sentido de regulamentação das telecomunicações, em que se inseria a gestão do espectro. Os principais marcos foram a edição do Código Brasileiro de Telecomunicações em 1962 e, principalmente, da Lei Geral das Telecomunicações, em 1997, que inaugurou o atual modelo do setor, trazendo entre suas inovações a substituição do papel do Estado de prestador monopolista de serviços, para a de agente regulador.

Merece especial destaque a premente necessidade de fiscalização do uso do espectro, de forma a se garantir que os interessados que possuem autorização tenham condições de utilizá-lo satisfatoriamente, bem como para coibir o uso de maneira imprópria por pessoas não autorizadas. Nesse sentido, as ações de físcalização da Anatel, sejam presenciais ou de monitoramento, representam um esforço na tentativa de se garantir a execução do interesse público, e não o beneficiamento ilícito de alguns.

Atualmente, ganham importância, entre as aplicações de RF, as redes locais sem fio, tais como os padrões Bluetooth e Wi-Fi. O fato de utilizarem tecnologias avançadas que permitem melhores características de comunicação, como espalhamento espectral e OFDM, além da crescente demanda por serviços de redes locais de dados, faz com que o uso nãolicenciado do espectro ganhe importância do ponto de vista da regulamentação de telecomunicações.

Outro assunto de grande interesse, especialmente para a população em geral, é a interação entre campos eletromagnéticos de RF e os tecidos biológicos do corpo humano. Em virtude do desconhecimento da sociedade e, em alguns casos, das informações incorretas veiculadas na imprensa, observa-se um temor infundado por parte de grande parte da população. 
Além dos assuntos mencionados, o processo de certificação e homologação de produtos para telecomunicações tem se mostrado uma forma de se estabelecer requisitos técnicos aos quais os produtos devem demonstrar conformidade antes de sua comercialização. Dessa maneira, tem-se maior garantia de que os equipamentos utilizados em radiocomunicação atendem a padrões operacionais que permitem o atendimento à regulamentação aplicável ao setor.

Verifica-se a enorme importância de uma eficiente regulação do espectro de radiofreqüências. Cabe, assim, uma maior atenção por parte dos responsáveis, devendo os entes de Estado envolvidos executar um trabalho que seja condizente com a importância do bom uso do espectro de radiofreqüências, tendo em vista o atendimento às necessidades da sociedade por serviços que utilizam comunicação sem fio. Destaca-se nesse contexto o serviço de radiodifusão, que tem uma relevante função social.

Dessa forma espera-se um maior respeito pela independência e autonomia do órgão regulador, a Anatel, de maneira que possa executar suas atribuições exclusivamente pautada nos princípios legais que regem seu funcionamento, tendo sempre como objetivo principal o interesse público, livre de influências externas seja por pressões políticas ou econômicas. 


\section{REFERÊNCIAS BIBLIOGRÁFICAS}

[1] STANTON, M., A administração do espectro eletromagnético. O Estado de São Paulo, São Paulo, 30 dez. 2002.

[2] JAKHU, R. S. International Regulatory Aspects of Radio Spectrum Management. Disponível em <http://www.law.mcgill.ca/institutes/csri/paper-jakhu-international.php3 $>$. Acesso em: 29/08/2005.

[3] KIRBY, R. C., History and Trends in International Radio Regulation. In: IEEE International Conference on 100 Years of Radio. Londres, 1995.

[4] ITU (International Telecommunication Union) - History. Disponível em:

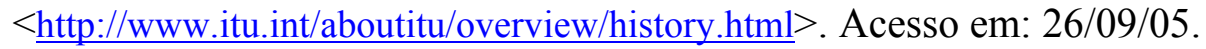

[5] JAMBEIRO, O., MOTA, A., RIBEIRO, A., COSTA, E., BRITO, F. A Radiodifusão Sob o Regime da Constituição de 1934. UFBA PIBIC/CNPq, 2000-2001. Disponível em $<$ http://www.eca.usp.br/alaic/material\%20congresso\%202002/congBolivia2002/trabalhos\%20complet os \%20Bolivia $\% 202002 / \mathrm{GT} \% 20 \% 202 \% 20 \% 20$ cesar $\% 20$ bolano/othon $\% 20$ jambeiro.doc $>$. Acesso em: 27/08/05.

[6] SIQUEIRA, E. Três Momentos da História das Telecomunicações no Brasil, 2. Ed. São Paulo: Alcatel, 1999.

[7] BRASIL. Lei n. ${ }^{\circ}$ 4.117, de 27/08/1962 - Institui o Código Brasileiro de Telecomunicações.

[8] BRASIL, Ministério das Comunicações. Exposição de Motivos n. ${ }^{\circ} 231$ - documento de encaminhamento da Lei Geral das Telecomunicações.

[9] BRASIL. Lei n. ${ }^{o} 9.472$ - Lei Geral de Telecomunicações - LGT, de 16/07/97 - Dispõe sobre a organização dos serviços de telecomunicações, a criação e funcionamento de um órgão regulador e outros aspectos institucionais, nos termos da Emenda Constitucional n. ${ }^{\circ}$, de 1995.

[10] ANATEL. Resolução n. ${ }^{\circ}$ 365, de 10/05/2004 - Republica o Regulamento sobre Equipamentos de Radiocomunicação de Radiação Restrita.

[11] TUDE, E. Quando não é necessário autorização para uso de Freqüências no Brasil.

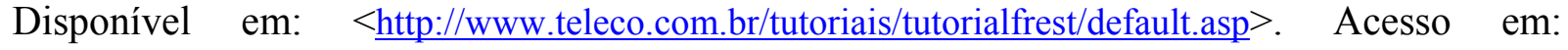
$14 / 02 / 05$. 
[12] MOBILEZONE. Glossário de termos técnicos e acrônimos de tecnologias móveis e sem fio. Disponível em: <http://www.mobilezone.com.br/glossario.htm>. Acesso em: 17/10/05.

[13] CARDOSO, F. R. M. e MACEDO-SOARES, J. C. T. Método para implementação de redes sem fio. Monografia de Graduação - Departamento de Engenharia Elétrica. Brasília: Universidade de Brasília, 2005.

[14] SILVA, L. M. Introdução à Radiodifusão Digital. Notas de aula. Radiodifusão Departamento de Engenharia Elétrica. Brasília: Universidade de Brasília, 2005.

[15] CHEN, J. C. 5GHz Wireless LAN Technology Enables the Real Internet. Disponível em: $<$ http://www.eetimes.com/isd/features/OEG20010130S0100>. Acesso em: 06/02/2006.

[16] RAVAGNANI JUNIOR, W. Bluetooth. Disponível em:

$<$ http://www.ic.unicamp.br/ ra007293/bluetooth/bluetooth.htm>. Acesso em: 22/10/2005.

[17] PINHEIRO, J. M. S. Por dentro do Bluetooth. Disponível em:

$<$ http://www.projetoderedes.com.br/artigos/artigo dentro bluetooth.php $>$. Acesso em: 23/10/05.

[18] ANATEL. Limitação da Exposição a Campos Eletromagnéticos. Disponível em:

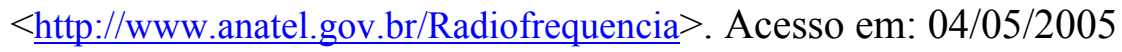

[19] TUDE, E. SAR e Radiação de Terminais Celulares. Disponível em: $<$ http://www.teleco.com.br/tutoriais/tutorialrsar/default.asp $>$. Acesso em 14/02/05.

[20] PAULINO, J. O. S. Radiações Eletromagnéticas não Ionizantes Emitidas pelas Antenas Fixas de Telefonia Celular. Departamento de Engenharia Elétrica - Escola de Engenharia, UFMG, maio de 2001.

[21] ANATEL. Diretrizes para Limitação da Exposição a Campos Elétricos, Magnéticos e Eletromagnéticos Variáveis no Tempo (Até 300 GHz). 1999.

[22] TAFLOVE, A. e HAGNESS, S. Computational Electrodynamics - The Finite Difference Time Domain Method. Norwood: Artech House, 1995.

[23] ANATEL. Resolução n. ${ }^{o}$ 303, de 02/07/2002 - Aprova o Regulamento sobre Limitação da Exposição a Campos Elétricos, Magnéticos e Eletromagnéticos na Faixa de Radiofreqüências entre 9 kHz e $300 \mathrm{GHz}$.

[24] UNEP (United Nations Environment Programme). Rio Declaration on Environment and Development. Disponível em:

$<$ http://www.unep.org/Documents/Default.asp?DocumentID=78\&ArticleID=1163 $>$. Acesso em: $17 / 05 / 05$.

[25] FOSTER, K. R. The Precautionary Principle - Common Sense or Environmental Extremism?. IEEE Tecnhology and Society Magazine, Volume 21, Number 4, Winter 2002/2003. 
[26] UK DEPARTMENT OF HEALTH. Mobile phones and health: Government response to the report from the Independent Expert Group on Mobile Phones (Stewart Group). Disponível em: $<$ http://www.dh.gov.uk/assetRoot/04/08/24/99/04082499.PDF>. Acesso em: 18/05/05.

[27] FEDERAL COMMUNICATIONS COMMISSION, Office of Engineering \& Technology. OET Bulletin 56 - Questions and Answers about Biological Effects and Potential Hazards of Radiofrequency Electromagnetic Fields - Fourth Edition, August 1999.

[28] CARDOSO, S. A. A. Radiações não-Ionizantes Emitidas pelas Estações Rádiobase do Sistema Móvel Celular. Monografia (Especialização em Regulação de Telecomunicações) Departamento de Engenharia Elétrica da Faculdade de Tecnologia. Brasília: Universidade de Brasília, 2004.

[29] KATZ, E. Biosensors \& Bioelectronics. The Hebrew University of Jerusalem - Faculty of Science - Institute of Chemistry. Disponível em:

$<$ http://chem.ch.huji.ac.il/ eugeniik/history/arsonval.html $>$. Acesso em: 18/05/05.

[30] WORLD HEALTH ORGANIZATION - International EMF Project. EMF World Wide Standards Database. Disponível em $<$ http://www.who.int/peh-emf/standards/en/ $>$. Acesso em 20/05/05.

[31] ANATEL. Resolução n. ${ }^{\circ}$ 259, de 19/04/2001 - Aprova o Regulamento de Uso do Espectro de Radiofreqüências.

[32] ANATEL. Resolução n. ${ }^{\circ}$ 376, de 02/09/2004 - Aprova a alteração do Regulamento sobre Condições de Uso de Radiofreqüências nas Faixas de $800 \mathrm{MHz}, 900 \mathrm{MHz}$ e $1.800 \mathrm{MHz}$ para prestação do Serviço Móvel Pessoal.

[33] BRASIL. Constituição da República Federativa do Brasil de 1988.

[34] ANATEL. Resolução n. ${ }^{\circ}$ 242, de 30/11/2000 - Aprova o Regulamento para Certificação e Homologação de Produtos para Telecomunicações.

[35] ANATEL. Certificação de Produtos. Disponível em:

$<$ http://www.anatel.gov.br/Certificacao $>$. Acesso em: 22/03/2005.

[36] ANATEL - Gerência de Certificação. Instrumento de Gestão n. ${ }^{\circ}$ 02, de 11/09/2002 Orientações para Classificação de Produtos para Telecomunicações por Família.

[37] ANATEL. Resolução n. ${ }^{\circ}$ 372, de 19/05/2004 - Aprova a Norma para Certificação e Homologação de Antenas Setoriais e Omnidirecionais.

[38] ANATEL. Resolução n. ${ }^{\circ}$ 367, de 13/05/2004 - Aprova a Norma para Certificação e Homologação de Antenas Direcionais de Abertura. 
[39] ANATEL. Resolução 366, de13/05/2004 - Aprova a Norma para Certificação e Homologação de Antenas Lineares.

[40] ANATEL. Resolução 237, de 09/11/2000 - Aprova o Regulamento para a Certificação de Equipamentos de Telecomunicações Quanto aos Aspectos de Compatibilidade Eletromagnética.

[41] ANATEL. Resolução 238, de 09/11/2000 - Aprova o Regulamento para a Certificação de Equipamentos de Telecomunicações Quanto aos Aspectos de Segurança Elétrica.

[42] ANATEL. SGCH - Sistema de Gestão de Certificação e Homologação. Disponível em: $<\underline{\text { http://sistemas.anatel.gov.br/sgch/>. }}$. 